\title{
GEOHYDROLOGY OF THE ENGLISHTOWN FORMATION IN THE NORTHERN COASTAL PLAIN OF NEW JERSEY
}

By W. D. Nichols

U.S. GEOLOGICAL SURVEY

Water-Resources Investigations $76-123$

Prepared in cooperation with the NEW JERSEY DEPARTMENT OF ENVIRONMENTAL PROTECTION, DIVISION OF WATER RESOURCES

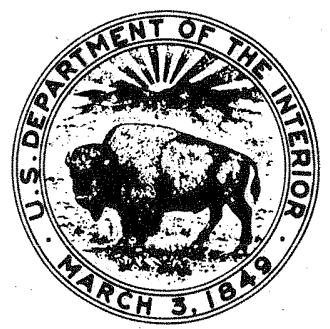

February 1977 


\author{
UNITED STATES DEPARTMENT OF THE INTERIOR \\ Thomas S. Kleppe, Secretary \\ GEOLOGICAL SURVEY \\ V. E. Mckelvey, Director
}

For additional information write to:

U.S. Geological Survey

Rm. 420 Federal Bldg.

P.0. Box 1238

Trenton, N.J. 08607 


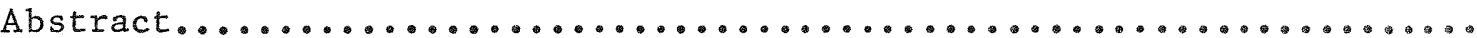

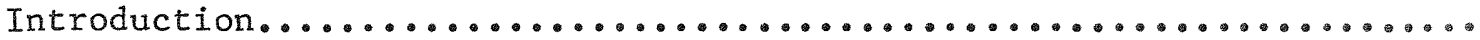

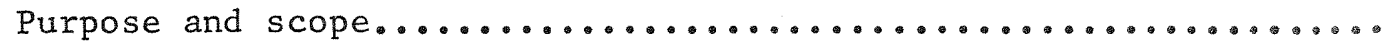

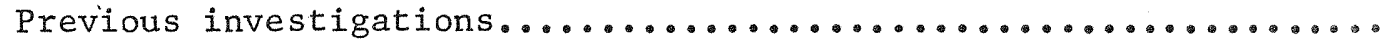

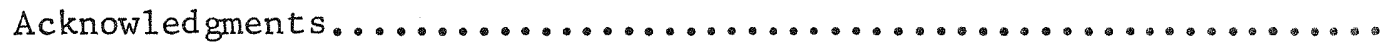

Stratigraphic summary of the Cretaceous formations of the northern

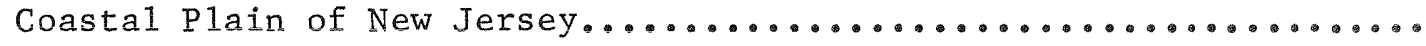

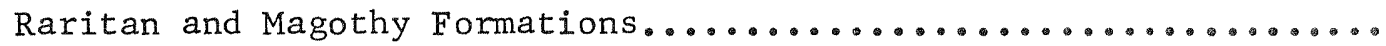

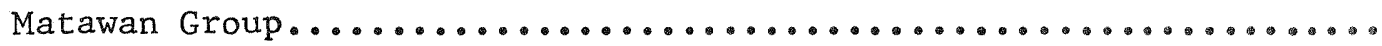

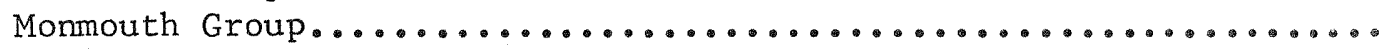

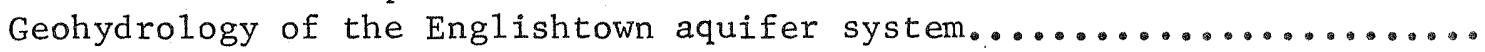

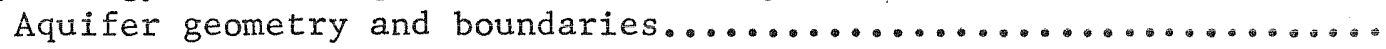

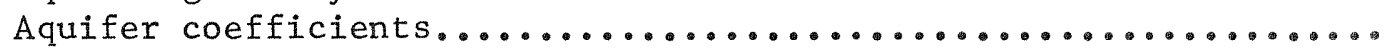

Regional configuration of the potentiometric surface and water-

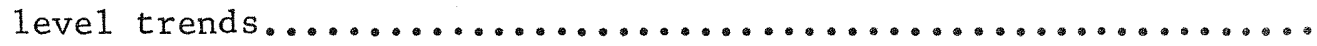

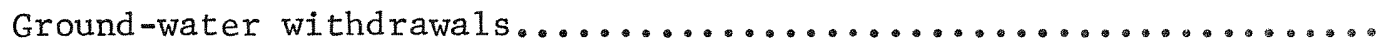

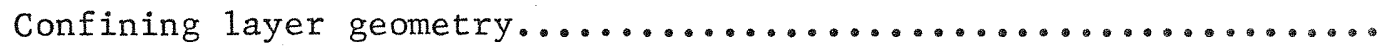

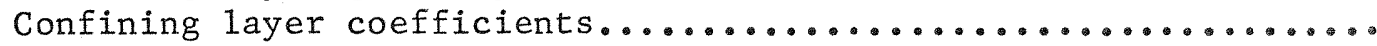

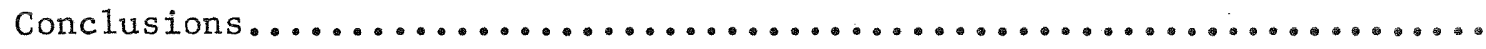

References cited.

Figure 1. Index map of New Jersey showing the area of investigation...

2. Map showing the combined thickness of the Merchantville

Formation and Woodbury Clay in Monmouth and northern

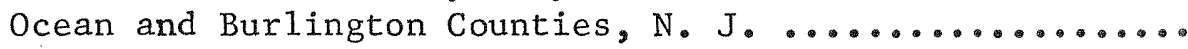

3. Map showing location of wells used for stratigraphic

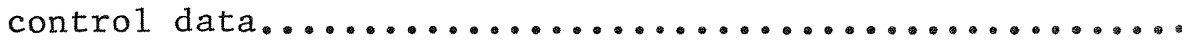

4. Structure-contour map of the top of the Englishtown

Formation in Monmouth and northern Ocean Counties, N. J.

5. Cross-sections $A-A^{\prime}$ and $B-B^{\prime}$ showing the sand and clayey silt lithofacies of the Englishtown aquifer in northern

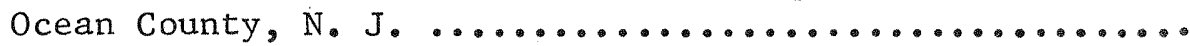

6. Map showing the thickness of the Englishtown Formation in Monmouth and northern Ocean and Burlington Counties,

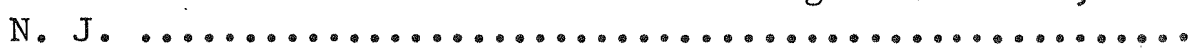

7. Map showing the thickness of the lower sand 1ithofacies of the Englishtown Formation in northern Ocean County, N. J.

8. Map showing the thickness of the clayey silt lithofacies
of the Englishtown Formation in northern Ocean County,

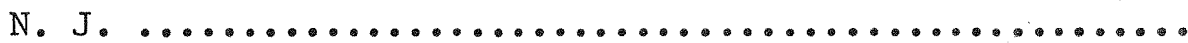

9. Map showing the thickness of the upper sand 1ithofacies of the Englishtown Formation in northern Ocean County, N. J.

10. Map showing the decline in water level between January,
1959, and November, 1970, in the Englishtown aquifer in

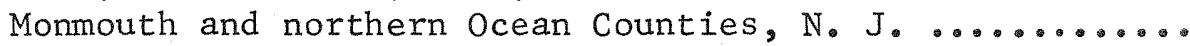


Figure 11. Map showing the thickness of the Englishtown aquifer in Monmouth County and of the upper sand lithofacies of the Englishtown Formation in northern Ocean and

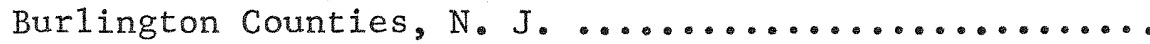

12. Map showing the transmissivity of the Englishtown aquifer in Monmouth and northern Ocean Counties, N. J. ........

13. Map showing the altitude of the potentiometric surface in the Englishtown aquifer about 1900, in Monmouth, and northern Ocean and Burlington Counties, N. J. ..........

14. Map showing the altitude of the potentiometric surface in the Englishtown aquifer in January, 1959, in Monmouth

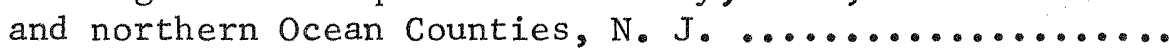

15. Map showing the decline in water level between about 1900 and January 1959 in the Englishtown aquifer in Monmouth

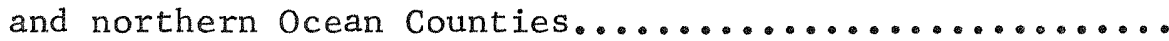

16. Map showing the altitude of the potentiometric surface in the Englishtown aquifer in November, 1970, in Monmouth and northern Ocean Counties, N. J. ..........

17. Hydrographs of observation wells tapping the Englishtown aquifer in Monmouth and northern Ocean Counties, N. J. .

A. Allaire State Park, U.S.G.S. observation we11, Monmouth County, N.J.

B. Colliers Mil1s, U.S.G.S. observation well TW 1, Ocean County, N. J.

C. Lakewood Water Company observation we11, Lakewood, Ocean County, N. J.

18. Location of pumping wells listed in table 8 and observation

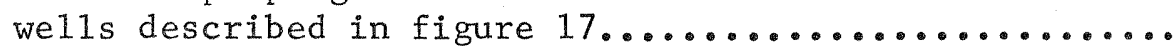

19. Map showing location of wells developed in the Englishtown

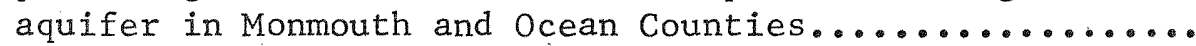

20. Map showing the thickness of the confining layer overlying the Englishtown aquifer in Monmouth, and northern Ocean

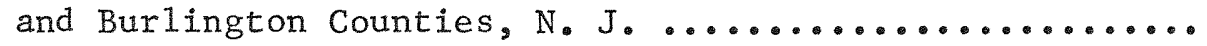

21. Sediment classification diagrams for selected samples from test holes penetrating the confining layers of the

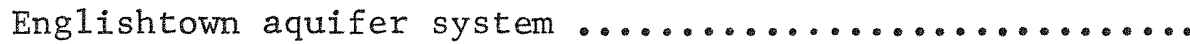

TABLES

Table 1. Stratigraphic units of the northern Atlantic Coastal Plain

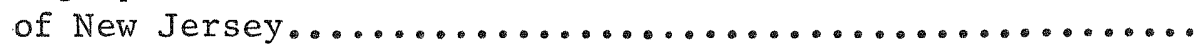

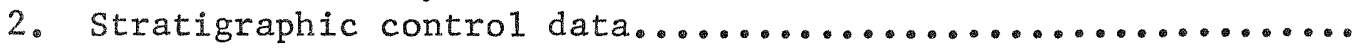

3. Estimated transmissivity and hydraulic conductivity of the Englishtown aquifer based on the specific capacity of

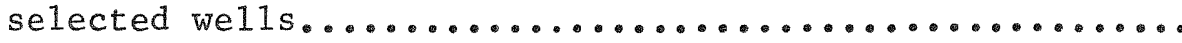

4. Extreme and average values of aquifer and confining layer

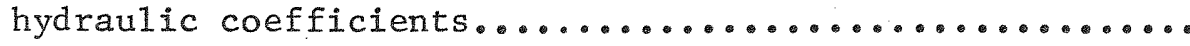


Table 5. Water-level data used in constructing 1900 potentiometric

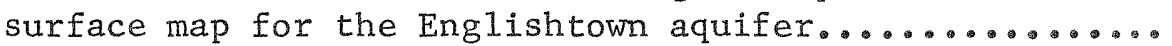

6. Yield and water-level data for wells developed in the Englishtown aquifer in Monmouth and Ocean Counties......

7. Construction data for wells developed in the Englishtown aquifer in Monmouth and Ocean Counties............... 34

8. Rate of ground-water withdrawal for public supply in

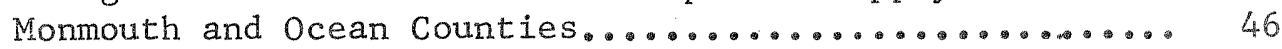

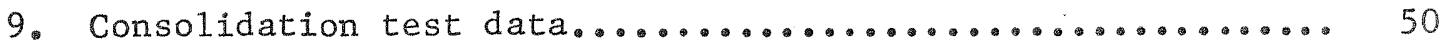




\section{CONVERSION FACTORS}

Factors for converting English units to the International System of Units (SI) are given below to four significant figures. However, in the text the metric equivalents are shown only to the number of significant figures consistent with the values for the English units.

English

ft (feet)

$\mathrm{ft} / \mathrm{s}$ (feet per second)

$\mathrm{ft} / \mathrm{mi}$ (feet per mile)

$\mathrm{ft}^{2} /$ day (square feet per day)

$\mathrm{ft}^{2} / \mathrm{s}$ (square feet per second)

gal/min (gallons per minute)

Mgal/d (million gallons per day)

$\mathrm{mi}^{2}$ (square miles)

psi (pounds per square inch)
Multiply by

Metric (SI) 


\title{
GEOHYDROLOGY OF THE ENGLISHTOWN FORMATION IN
}

\author{
THE NORTHERN COASTAL PLAIN OF NEW JERSEY
}

By W. D. Nichols

\section{ABSTRACT}

The Englishtown Formation of the Matawan Group of Late Cretaceous age is exposed in the western part of the New Jersey Coastal Plain along a northeast-southwest trending zone extending from Raritan bay to Delaware Bay. In outcrop, in the northern part of the Coastal Plain, the Englishtown typically consists of a series of thin, cross-stratified, fine- to medium-grained lignitic quartz sand beds intercalated with thin beds of sandy silty clay and clayey silt, ranging in total thickness from about 140 feet ( 43 meters) near Raritan Bay to about 50 feet (15 meters) near Trenton. In the subsurface of the northern part of the Coastal Plain, the formation retains most of the lithologic characteristics displayed in outcrop. In northern and eastern Ocean County the Englishtown can be subdivided into three distinct lithologic units; upper and lower units of quartz sand with thin interbeds of dark sandy silt, separated by a thick sequence of sandy and clayey lignitic silt.

The confined part of the aquifer in the Englishtown Formation is utilized as a source of water over an area of about 1,100 square miles $(2,849$ square kilometers) of the New Jersey Coastal Plain and is an important source of supply in Monmouth and northern Ocean Counties. The annual average rate of withdrawal from the aquifer in the two-county area increased from 5.5 million gallons per day $(0.24$ cubic meters per second) in 1959 to 9.5 million gallons per day ( 0.4 cubic meters per second) in 1970. Water levels in parts of this area were declining 8 to 12 feet (2.4 to 3.6 meters) per year as of 1970 and they declined as much as 140 feet ( 43 meters) between 1959 and 1970 near pumping centers. The aquifer transmissivity ranges from 2,400 square feet per day to 650 square feet per day (223 square meters per day to 60 square meters per day); the estimated hydraulic conductivity ranges from about 11 feet per day to 20 feet per day ( 3.3 meters per day 506.1 meters per day); and the storage coefficient ranges from $8 \times 10^{-5}$ to $3 \times 10^{-4}$. The underlying and overlying confining beds, which have an average thickness of 200 feet ( 61 meters) and 40 feet (12 meters), respectively, have vertical hydraulic conductivities on the order of $1 \times 10^{-5}$ feet per day $\left(3 \times 10^{-6}\right.$ meters per day) and specific storage on the order of $8 \times 10^{-5}$ $\mathrm{ft}^{-1}\left(2.4 \times 10^{-5} \mathrm{~m}^{-1}\right)$. 
The Englishtown aquifer is an integral part of the complex multiaquifer system of the New Jersey Coastal Plain. The withdrawal of water from the Englishtown aquifer has had a marked effect on the water level in the overlying Mount Laurel aquifer, and these effects will continue so long as the water level in the Englishtown continues to decline. Any increase in the development of the Mount Laurel aquifer that reduces the volume of leakage to the Englishtown will cause an increase in the rate of water-level decline in the Englishtown even with no increase in direct withdrawals. The interrelationship and interdependency between pumping stresses in individual aquifers within the complex Coastal plain aquifer system must be recognized and appreciated, and the hydrodynamics of all parts of the system must be considered if reliable predictions of aquifer response to these stresses are to be made. Such predictions generally require a simulation model analysis of the system.

\section{INTRODUCTION}

The aquifer in the Englishtown Formation of the Matawan Group of Late Cretaceous age is one of the more important sources of ground-water supplies in the northern part of the New Jersey Coastal Plain. Total ground-water withdrawals for public supply in Monmouth and northern Ocean Counties increased from $5.5 \mathrm{Mgal} / \mathrm{d}$ (million gallons per day) $\left[0.24 \mathrm{~m}^{3} / \mathrm{s}\right.$ (cubic meters per second)] in 1959 to $9.5 \mathrm{Mgal} / \mathrm{d}(0.4 \mathrm{~m} / \mathrm{s})$ in 1970 . A1though these withdrawals may seem small in comparison with withdrawals from ground-water sources in other areas, they have placed a considerable stress on the Englishtown aquifer. Water levels in the aquifer have been declining at the rate of 8 to $12 \mathrm{ft}$ (feet) [2.4 to $3.6 \mathrm{~m}$ (meters)] per year over large areas since 1959. The rate of decline has accelerated during the past several years in some areas, near pumping centers, in response to increased withdrawals.

Recognizing the need for quantitative solutions to the questions arising from the demands for continued increased development of the ground-water resources of the New Jersey Coastal Plain, the U.S. Geological Survey began a program of regional geohydrologic studies of the aquifers in the Coastal Plain aquifer system in cooperation with the Division of Water Resources of the New Jersey Department of Environmental Protection. These studies, in addition to utilizing the applicable analytical techniques needed to define system parameters, include simulation modeling of individual aquifers. The models in most, if not al1, cases are to be digital computer simulation models and will serve three specific purposes. First, the modeling effort will identify those data that are essential to a quantitative study of the hydraulics of the aquifer and the areas where such data are most needed. second, the model will provide a tool for the investigator to test and evaluate different concepts of the functioning of the ground-water system. Third, when completed and calibrated, the model will be a tool that can be used by the water-resource planner and manager to predict the effects of alternative schemes of resource development. 
The purpose of this first report is to define the geohydrologic parameters required for a quantitative analysis of the aquifer system. The geologic framework of the Englishtown Formation is briefly discussed. The 1ithologic character of the formation is described, and the geometry of the aquifer and adjacent confining beds is defined. The hydraulic parameters that control the movement of water in the aquifer system are given. These parameters have been computed from field and laboratory test data. The data presented and the concepts of the response of the aquifer system to stress provide the basis for the concurrent construction and development of a digital computer simulation model of the Englishtown aquifer system.

The investigation covers an area of about $1,450 \mathrm{mi}^{2}$ (square miles) $\left[3,755 \mathrm{~km}^{2}\right.$ (square kilometers)] of the northern Coastal Plain of New Jersey and includes Monmouth and parts of Ocean and Burlington Counties (fig, 1). The simulation model of the Englishtown aquifer covers about $750 \mathrm{mi}^{2}(1,942$ $\mathrm{km}^{2}$ ) within the area of study and includes Monmouth County, northern Ocean County, and extreme northeastern Burlington County (fig. 1).

Most of the geologic and hydrologic data for the Englishtown aquifer system are presented in a series of tables. Stratigraphic control data used in constructing the various isopach maps and the structure contour map of the Englishtown Formation are given in table 2. The altitude and thickness data are based on interpretation of geophysical logs, most of which were collected by the U.S. Geological Survey. The stratigraphic control well locations are shown on figure 3. Water-level data used in constructing the "pre-pumping" potentiometric surface map (fig. 13) are given in table 5, and the approximate locations of the wells from which the measurements were obtained are shown on figure 13. Well-yield characteristics and well construction characteristics for all Englishtown wells are given in tables 6 and 7, respectively. Water-level data collected in 1959 and 1970 are also given in table 6. The locations of all wells given in tables 6 and 7 are shown on figure 19. The average annual rate of withdrawal for public supply from the Englishtown aquifer for the years 1959 through 1970 is given in table 8 . The results of soil consolidation tests conducted on undisturbed core samples of confining layers in the New Jersey Coastal Plain are presented in table 9 .

\section{Previous Investigations}

The geology of the Coastal Plain of New Jersey and of the Englishtown Formation has been discussed by several authors. Among the more recent studies are those by Owens and others (1970), Minard (1969), Minard and others (1969), Owens and Soh1 (1969), Owens and Minard (1966, 1970), and Minard (1964). A more extensive list of references to the geologic literature of the New Jersey Coastal Plain and the Englishtown and adjacent formations can be found in the articles cited above. 


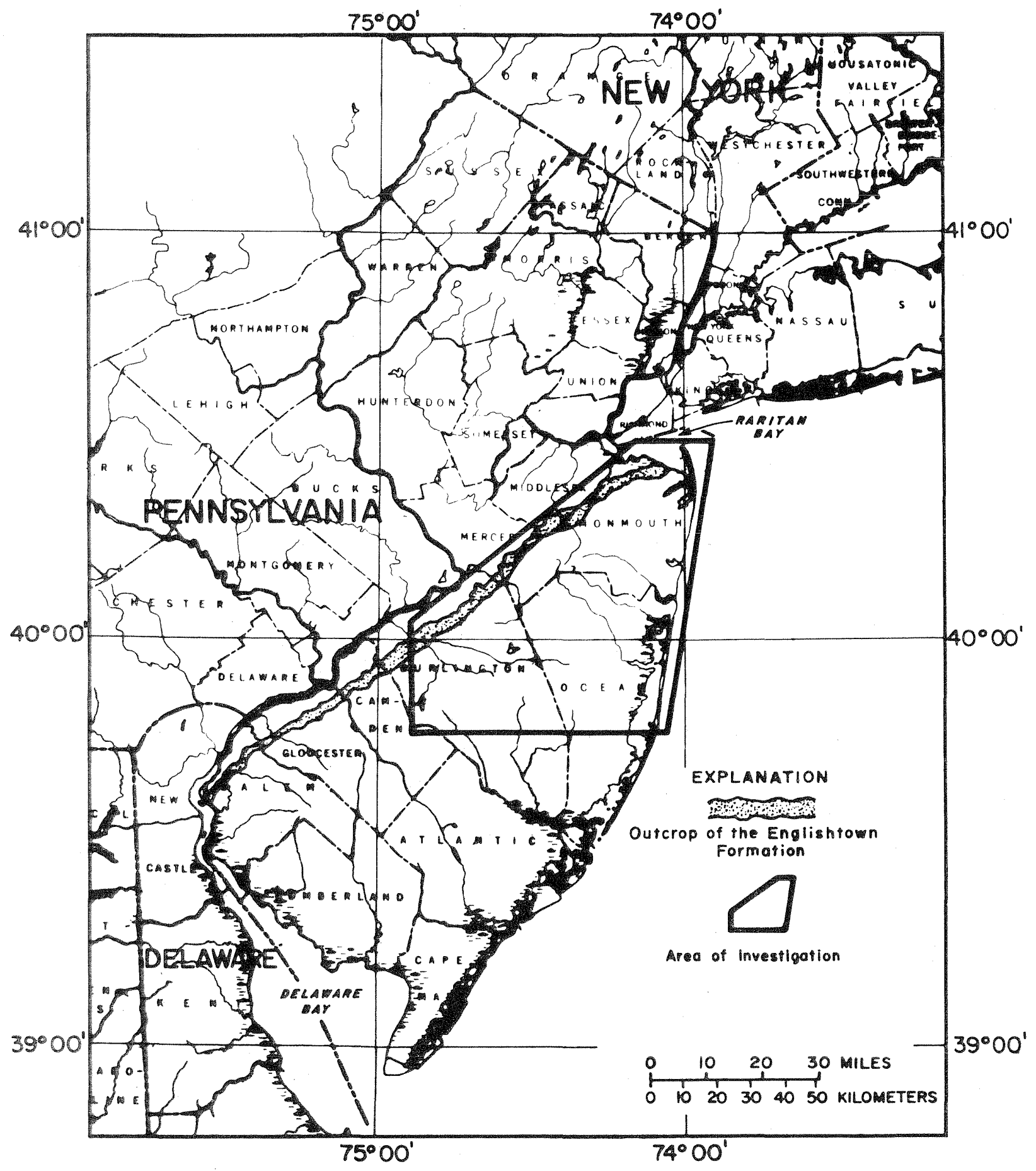

FIGURE 1. - INDEX MAP OF NEW JERSEY SHOWING AREA OF INVESTIGATION. 
The regional hydrology of the Englishtown Formation is discussed briefly by Barksdale and others (1958) and by Parker and others (1964). Reports by Jablonski (1959, 1960, 1968) on Monmouth County; Rush (1962, 1968) on Burlington County; Anderson and Appe1 (1969) on Ocean County; Donsky (1963) and Farlekas and others (1974) on Camden County; Vecchioli and Palmer (1962) on Mercer County; Hardt (1963) and Hardt and Hilton (1969) on Gloucester County; and Rosenau and others (1969) on Salem County contain wel1 records, logs, chemical analyses, and brief descriptions of the geology, hydrology, and water quality of the Englishtown Formation in these counties. Seaber (1965) has given a short discussion of the geology and geohydrology of the Englishtown Formation and a more extensive discussion of the chemical quality of the water in the Englishtown throughout much of the formation in the New Jersey Coastal Plain.

\section{Acknowledgments}

This investigation was conducted by the U.S. Geological Survey in cooperation with the Division of Water Resources of the New Jersey Department of Environmental Protection. Bronius Nemickas, Richard E. Hodges, Harry Farsett, William Cushing, and Floyd Price assisted the author in the collection, compilation, and analysis of basic data. Harold E. Gill provided invaluable guidance and assistance in the interpretation of geophysical logs during the early stages of the investigation.

\section{STRATIGRAPHIC SUMMARY OF THE CRETACEOUS FORMATIONS OF THE NORTHERN COASTAL PLAIN OF NEW JERSEY}

The New Jersey Coastal Plain is underlain by a wedge-shaped mass of unconsolidated and partly consolidated marine, marginal marine, and nonmarine deposits of clay, silt, sand, and gravel. The sediments range in age from Cretaceous to Holocene (table 1) and lie unconformably on the pre-Cretaceous basement. The total thickness of the sedimentary sequence in outcrop ranges from 500 to $1,000 \mathrm{ft}$ (152 to $305 \mathrm{~m}$ ); the sequence thickens downdip, toward the southeast, and attains a maximum aggregate thickness of about $6,500 \mathrm{ft}(1,980 \mathrm{~m})$ at the extreme southern tip of New Jersey.

The geology of the pre-Quaternary Coastal Plain formations of New Jersey has been discussed by several investigators and was recently summarized by Owens and Minard (1970) and Owens and Soh1 (1969). These studies, especially the more recent ones, have shown that there are significant differences in the character and occurrence of these formations between Raritan Bay in the northeast and Delaware Bay to the southwest. The differences reflect the varying patterns and environments of sedimentation that existed throughout the region, especially during Late Cretaceous time. Depositional patterns in the northern Coastal Plain of New Jersey seem to have been controlled largely by two basement tectonic elements; a trough or small basin centering in the vicinity of Raritan Bay and a northwestsoutheast trending high in southern New Jersey. 
Table 1,--Stratigraphic units of the northern Atlantic Coastal Plain of New Jersey ${ }^{1 /}$

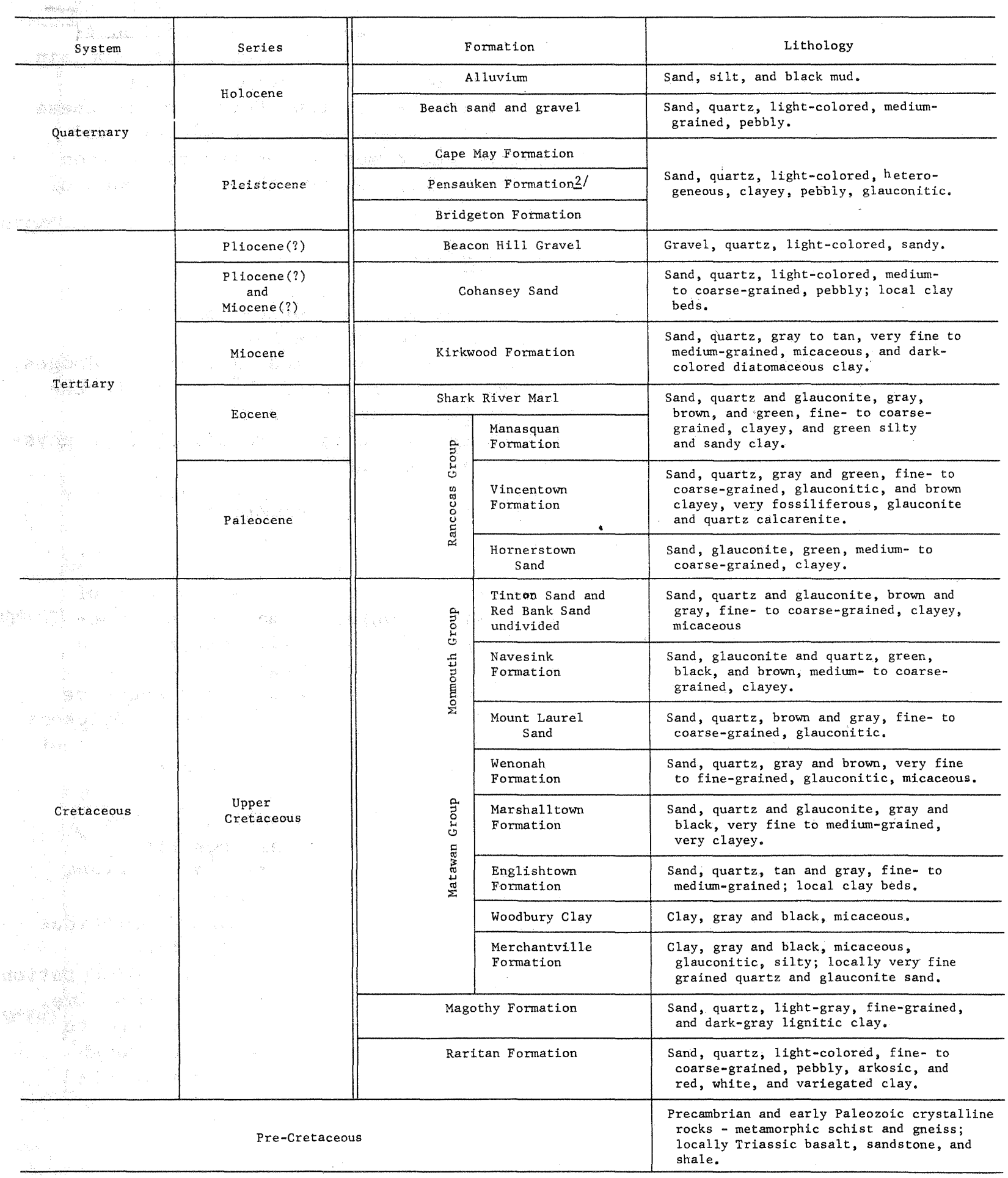

$1 /$ Modified after Seaber, 1965, table 3 .

$2 /$ Age of Pensauken Formation now considered late Miocene. 
The Raritan Formation is the oldest stratigraphic unit in the northern Coastal Plain of New Jersey. This formation, which lies unconformably on the pre-Cretaceous basement, consists chiefly of interstratified lightcolored sands and dark or variegated silty clays and clayey silts. Depositional environments ranging from marine and marginal marine to those of a subaerial and subaquaceous deltaic plain (Owens and others, 1968) are represented in the various beds of this formation. The Raritan has a maximum thickness, in outcrop, of about $500 \mathrm{ft}(152 \mathrm{~m})$ in the northern $\mathrm{New}$ Jersey Coastal Plain.

The Magothy Formation overlies the Raritan Formation throughout New Jersey. In the Raritan Bay area the Magothy consists of three units; a basal unit of massive to laminated dark micaceous silt, a middle unit of thin-bedded dark clays and silts and light-colored sand, and an upper unit of cross-bedded sand (Owens and Soh1, 1969). Farther south, near Trenton, the Magothy consists of a unit of light-colored cross-bedded sand, which has been correlated (Berry, 1906) with the uppermost unit of the Magothy at Raritan Bay. Along its outcrop, the Magothy ranges in thickness from about $175 \mathrm{ft}(53 \mathrm{~m})$ near Raritan Bay to about $500 \mathrm{ft}$ (152 ill) near Trenton.

\section{Matawan Group}

The Matawan Group is divided into five formations; ascending they are the Merchantville Formation, Woodbury Clay, Englishtown Formation, Marshalltown Formation, and Wenonah Formation. The Merchantville Formation disconformably overlies the Magothy throughout the New Jersey Coastal Plain. It consists primarily of an interbedded marine sequence of dark-colored thin micaceous clayey silt and very fine silty sand with massive thick beds of silty glauconite sand in the Raritan Bay area. The formation becomes thicker bedded toward the southwest.

The Woodbury Clay overlies the Merchantville Formation in the northern and central part of the New Jersey Coastal Plain. It pinches out in the area just north of Swedesboro in southwestern New Jersey and is not seen in outcrop south of that point. The contact between the two formations is gradationa1. The Woodbury is a massive-bedded dark-gray to grayish-black lignitic sandy to clayey silt and silty clay of marine origin.

The Merchantville Formation and Woodbury Clay are both about $50 \mathrm{ft}$ $(15 \mathrm{~m})$ thick along their outcrop between Trenton and Raritan Bay. South and southeast from the outcrop area, the combined thickness of the Merchantville Formation and Woodbury Clay gradually increases to about 200 ft $(61 \mathrm{~m})$. The total thickness of the two units then increases sharply to more than $300 \mathrm{ft}(91 \mathrm{~m})$ over a roughly elliptically shaped area of southeastern Monmouth County. An isopach map of the combined thickness of the two formations is shown in figure 2. The thickness data used in constructing the map is given in table 2. The location of stratigraphic control wells are shown on figure 3 . 


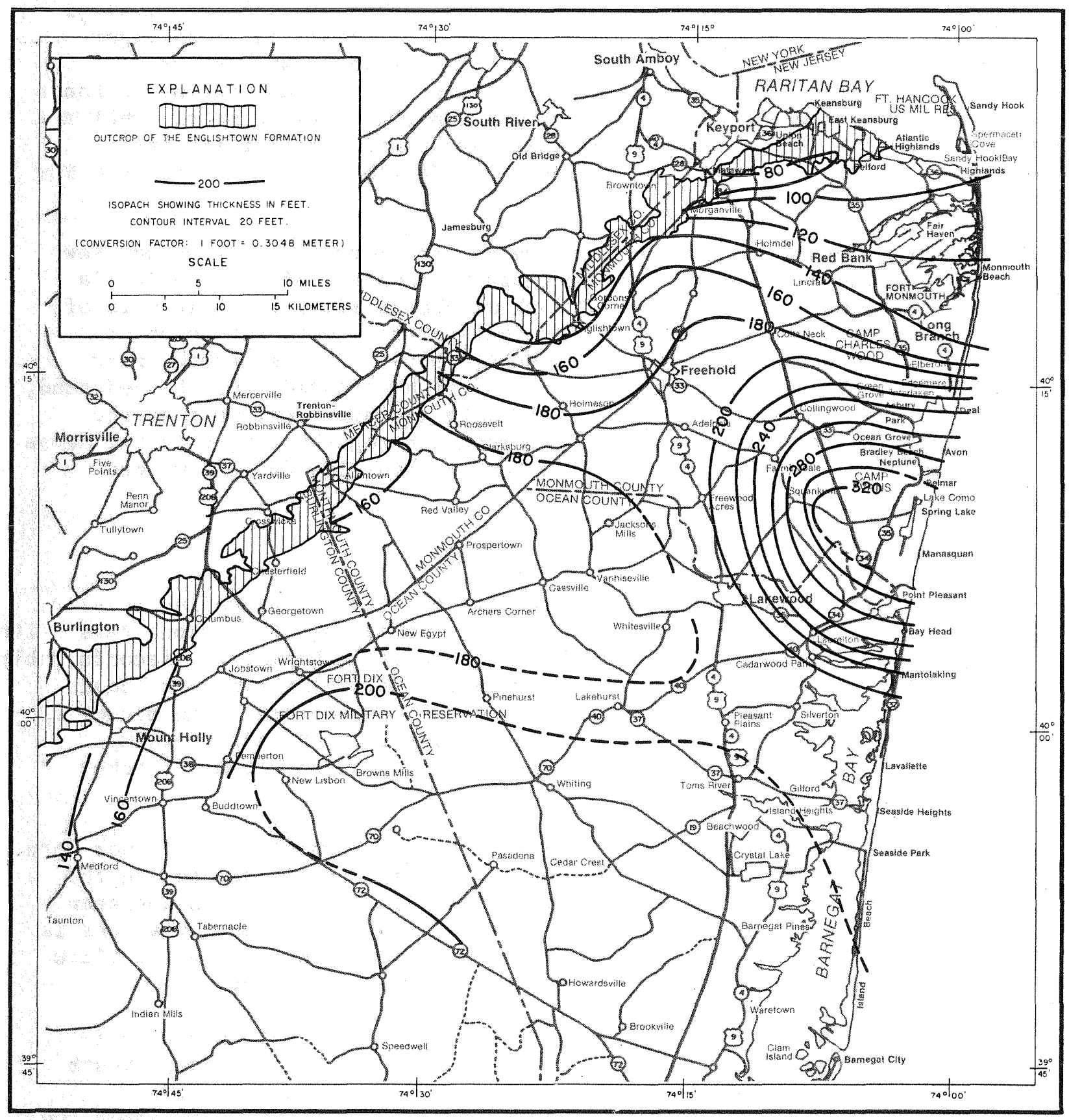

FIGURE 2. - COMBINED THICKNESS OF THE MERCHANTVILLE FORMATION AND WOODBURY CLAY IN MONMOUTH AND NORTHERN OCEAN AND BURLINGTON COUNTIES, N.J. 


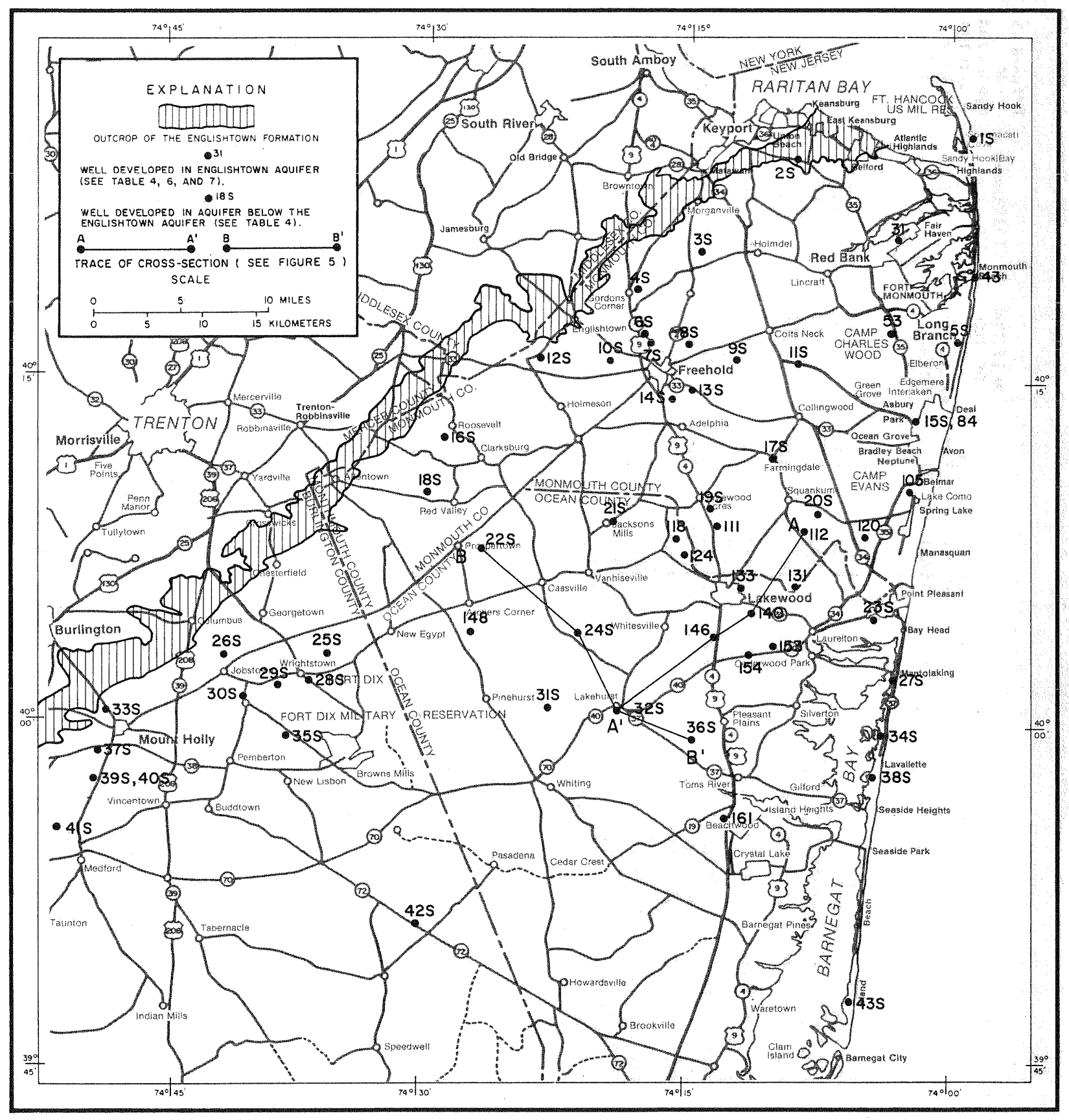

FIGURE 3. --LOCATION OF WELLS USED FOR STRATIGRAPHIC CONTROL DATA. 


\begin{tabular}{|c|c|c|c|c|c|c|c|c|c|c|}
\hline $\begin{array}{l}\text { MAP } \\
\text { NO }\end{array}$ & LOCATION & OWNFR & $\begin{array}{l}\text { LOCAL } \\
\text { NELL } \\
\text { NUMER }\end{array}$ & $\begin{array}{l}\text { ALTI- } \\
\text { TUDE- } \\
\text { OF LSD } \\
\text { (FT) }\end{array}$ & $\begin{array}{l}\text { DATE } \\
\text { DRILLED } \\
\text { (YEAR) }\end{array}$ & $\begin{array}{l}\text { WELL } \\
\text { DEPTH } \\
\text { (FT) }\end{array}$ & $\begin{array}{l}\text { ALTITUDE } \\
\text { OF TOP } \\
\text { OF } \\
\text { ENGLISHTOWN } \\
\text { FORMATION }\end{array}$ & $\begin{array}{l}\text { THICKNESS } \\
\text { OF } \\
\text { ENGLISHTOWN } \\
\text { FORMATION } \\
\text { (FT) }\end{array}$ & $\begin{array}{c}\text { THICKNESS } \\
\text { OF } \\
\text { OVERLYING } \\
\text { CONFINING } \\
\text { LAYER } \\
\text { (FT) }\end{array}$ & $\begin{array}{c}\text { THICKNESS } \\
\text { OF } \\
\text { UNDERLYIN } \\
\text { CONFINING } \\
\text { LAYER } \\
\text { (FT) }\end{array}$ \\
\hline $\begin{array}{r}31 \\
43 \\
53 \\
84 \\
105\end{array}$ & $\begin{array}{l}402114 N 0740315.1 \\
401927 N 0735842.1 \\
401720 N 0740315.1 \\
401322 N 0740155.1 \\
401025 N 0740212.1\end{array}$ & $\begin{array}{l}\text { RED BANK WD } \\
\text { MON BCH CLD STR } \\
\text { R H MACY \& CO } \\
\text { MONMOUTH CON WC } \\
\text { WALL TWP W D }\end{array}$ & $\begin{array}{l}\text { RBWD } 2 \\
\text { MBCS } 2 \\
\text { BAMBERGER TEST } \\
\text { WHITESVILLE } 3 \\
\text { WEST BELMAR }\end{array}$ & $\begin{array}{l}30 \\
10 \\
70 \\
10 \\
25\end{array}$ & $\begin{array}{l}1956 \\
1961 \\
1957 \\
1954 \\
1959\end{array}$ & $\begin{array}{l}300 \\
430 \\
430 \\
566 \\
575\end{array}$ & $\begin{array}{l}-112 \\
-286 \\
-280 \\
-436 \\
-541\end{array}$ & $\begin{array}{r}138 \\
136 \\
116 \\
104 \\
30\end{array}$ & $\begin{array}{l}42 \\
42 \\
42 \\
40 \\
35\end{array}$ & $\begin{array}{l}-\infty \\
144 \\
-\infty\end{array}$ \\
\hline $\begin{array}{l}111 \\
112 \\
118 \\
120 \\
124\end{array}$ & $\begin{array}{l}400908 N 0741330.1 \\
400832 N 0740821.1 \\
400823 N 0741520.1 \\
400824 N 0740508.1 \\
400742 N 0741639.1\end{array}$ & $\begin{array}{l}\text { ALDRICH W CO } \\
\text { US GEOL SURVEY } \\
\text { JACKSON TWP MUA } \\
\text { WALL TWD WD } \\
\text { JACKSON TWP MUA }\end{array}$ & $\begin{array}{l}\text { ALDRICH } 1 \text { CO } 4 \\
\text { ALLAIRE } 5 \text { P C } \\
\text { JACKSON } 2 \\
\text { ALLENWOOD } 2 \\
\text { JACKSON } 4\end{array}$ & $\begin{array}{r}130 \\
96 \\
156 \\
80 \\
80\end{array}$ & $\begin{array}{l}1967 \\
1963 \\
1962 \\
1959 \\
1965\end{array}$ & $\begin{array}{l}550 \\
633 \\
577 \\
710 \\
500\end{array}$ & $\begin{array}{l}-380 \\
-469 \\
-330 \\
-524 \\
-366\end{array}$ & $\begin{array}{l}564 \\
108 \\
118 \\
74 \\
138\end{array}$ & $\begin{array}{l}40 \\
40 \\
40 \\
44 \\
50\end{array}$ & $\begin{array}{l}= \\
= \\
= \\
=\end{array}$ \\
\hline $\begin{array}{l}133 \\
131 \\
140 \\
146 \\
148\end{array}$ & $\begin{array}{l}400614 N 0741157.1 \\
400555 N 0740851.1 \\
400500 N 0741108.1 \\
400443 N 0741352.1 \\
400416 N_{0} 742701.1\end{array}$ & $\begin{array}{l}\text { LAKEWOOD W C } \\
\text { PARKWAY WC } \\
\text { LAKEWOOD W C } \\
\text { LAKEWOOD C C } \\
\text { US GEOL SURVEY }\end{array}$ & $\begin{array}{l}\text { LAKEWOOD } 9 \\
\text { PARKWAY } 1 \\
\text { LAKEWOOD } \\
\text { LAKEWOOO } 8 \\
\text { COLL MILLS TW }\end{array}$ & $\begin{array}{r}55 \\
45 \\
30 \\
78 \\
137\end{array}$ & $\begin{array}{l}1968 \\
1958 \\
1966 \\
1965 \\
1964\end{array}$ & $\begin{array}{l}698 \\
646 \\
736 \\
758 \\
427\end{array}$ & $\begin{array}{l}-478 \\
-558 \\
-552 \\
-520 \\
-249\end{array}$ & $\begin{array}{l}170 \\
1244 \\
170 \\
160 \\
96\end{array}$ & $\begin{array}{r}54 \\
50 \\
94 \\
100 \\
44\end{array}$ & $\begin{array}{l}-\infty \\
=- \\
=\end{array}$ \\
\hline $\begin{array}{r}153 \\
154 \\
161 \\
15 \\
2 S\end{array}$ & $\begin{array}{l}400358 \text { N0740812.1 } \\
400312 N_{0} 741123.1 \\
395609 N_{0} 741240.1 \\
402536 N_{0} 735905.1 \\
402449 \text { N0 } 740910.1\end{array}$ & $\begin{array}{l}\text { BRADLEES CORP } \\
S \text { LAKEWOOD WC } \\
\text { US GEOL SURVEY } \\
\text { STATE OF NJ } \\
\text { LILY TULIP CUP }\end{array}$ & $\begin{array}{l}\text { BRADLEES WELL } \\
\text { S LAKEWOOD } 3 \\
\text { TOMS RIVER TW2 } \\
\text { SANDY HOOK SPI } \\
\text { DEEP TEST WELL }\end{array}$ & $\begin{array}{l}10 \\
45 \\
15 \\
10 \\
60\end{array}$ & $\begin{array}{l}1969 \\
1966 \\
1965 \\
1965 \\
1969\end{array}$ & $\begin{array}{r}710 \\
741 \\
1146 \\
397 \\
799\end{array}$ & $\begin{array}{r}-640 \\
-616 \\
-886 \\
-55 \\
--\end{array}$ & $\begin{array}{l}624 \\
544 \\
222 \\
146 \\
122\end{array}$ & $\begin{array}{l}48 \\
62 \\
46 \\
10 \\
-\infty\end{array}$ & $\begin{array}{l}-\infty \\
-\infty \\
80\end{array}$ \\
\hline $\begin{array}{r}3 \mathrm{~S} \\
.4 \mathrm{~S} \\
5 \mathrm{~S} \\
6 \mathrm{~S} \\
7 \mathrm{~S}\end{array}$ & $\begin{array}{l}402102 N 0741353.1 \\
401902 N 0741811.4 \\
401639 N_{0} 735936.1 \\
401633 N 0741728.1 \\
401633 N_{0} 0741726.2\end{array}$ & $\begin{array}{l}\text { MARLBORO S HOSP } \\
\text { GORDONS W C } \\
\text { MONMOUTH CONSOL } \\
\text { FREEHOLD W D } \\
\text { FREEHOLD W D }\end{array}$ & $\begin{array}{l}\text { STATE HOSP } 15 \\
\text { GORDONS } 4 \\
\text { MCWC } 1 \\
\text { FREEHOLD } 3 \\
\text { TOP.LAKE TEST }\end{array}$ & $\begin{array}{r}135 \\
150 \\
10 \\
120 \\
110\end{array}$ & $\begin{array}{l}1966 \\
1968 \\
1956 \\
1964 \\
1967\end{array}$ & $\begin{array}{l}810 \\
810 \\
981 \\
567 \\
585\end{array}$ & $\begin{array}{r}+17 \\
+38 \\
-384 \\
+16 \\
+34\end{array}$ & $\begin{array}{r}70 \\
80 \\
122 \\
108 \\
100\end{array}$ & $\begin{array}{l}14 \\
19 \\
42 \\
36 \\
24\end{array}$ & $\begin{array}{l}148 \\
164 \\
140 \\
160 \\
178\end{array}$ \\
\hline $\begin{array}{r}8 \mathrm{~S} \\
9 \mathrm{~S} \\
10 \mathrm{~S} \\
11 \mathrm{~S} \\
12 \mathrm{~S}\end{array}$ & $\begin{array}{l}401625 N_{0} 741501.2 \\
401609 N 0741206.1 \\
401607 N 0742014.1 \\
401558 N 0740908.1 \\
401557 N_{0} 742318.1\end{array}$ & $\begin{array}{l}\text { SO GULF UTIL } \\
\text { HARMONY GOLF CL } \\
\text { BATTLEGROUND CC } \\
\text { NAD EARLE } \\
\text { BOY SCOUTS AMER }\end{array}$ & $\begin{array}{l}\text { SO GULF } 2 \\
\text { HARMON GOLF } 1 \\
\text { IRRIGATION } \\
\text { NAD EARLE } 2 \\
\text { QUAIL HILL } 2\end{array}$ & $\begin{array}{l}195 \\
135 \\
125 \\
135 \\
250\end{array}$ & $\begin{array}{l}1966 \\
1963 \\
1967 \\
1944 \\
1967\end{array}$ & $\begin{array}{l}656 \\
712 \\
569 \\
836 \\
527\end{array}$ & $\begin{array}{r}-66 \\
-137 \\
+6 \\
-202 \\
+62\end{array}$ & $\begin{array}{r}92 \\
98 \\
100 \\
98 \\
62\end{array}$ & $\begin{array}{l}36 \\
12 \\
26 \\
22 \\
16\end{array}$ & $\begin{array}{l}190 \\
186 \\
174 \\
210 \\
152\end{array}$ \\
\hline $\begin{array}{l}13 \mathrm{~S} \\
14 \mathrm{~S} \\
15 \mathrm{~S} \\
16 \mathrm{~S} \\
17 \mathrm{~S}\end{array}$ & $\begin{array}{l}401510 N_{0} 741604.1 \\
401412 N 07416.06 .1 \\
401322 N 0740202.1 \\
401223 N_{0} 742847.1 \\
401134 N_{0} 741014.1\end{array}$ & $\begin{array}{l}\text { NESTLE CO } \\
\text { FREEHOLD TWP WD } \\
\text { MONMOUTH CON WC } \\
\text { WILLIAM LEE } \\
\text { ROKEACH SONS }\end{array}$ & $\begin{array}{l}3 \text { SUPPLY } \\
\text { KOENIG LANE } 1 \\
\text { WHITESVILLE } 4 \\
\text { ROKEACH 1- }\end{array}$ & $\begin{array}{r}155 \\
130 \\
25 \\
175 \\
80\end{array}$ & $\begin{array}{l}1970 \\
1957 \\
1956 \\
1960 \\
1961\end{array}$ & $\begin{array}{l}650 \\
670 \\
957 \\
456 \\
885\end{array}$ & $\begin{array}{r}-71 \\
-92 \\
-421 \\
+50 \\
-302\end{array}$ & $\begin{array}{r}1104 \\
100 \\
100 \\
76 \\
102\end{array}$ & $\begin{array}{l}28 \\
32 \\
44 \\
32 \\
52\end{array}$ & $\begin{array}{l}186 \\
172 \\
242 \\
165 \\
261\end{array}$ \\
\hline $\begin{array}{l}18 \mathrm{~S} \\
19 \mathrm{~S} \\
20 \mathrm{~S} \\
21 \mathrm{~S} \\
22 \mathrm{~S}\end{array}$ & $\begin{array}{l}401005 \mathrm{~N} 0742939.1 \\
400957 \mathrm{NO} 741317.1 \\
400921 \mathrm{NO} 740743.1 \\
400853 \mathrm{~N} 0741925.1 \\
400733 \mathrm{NO} 742635.1\end{array}$ & $\begin{array}{l}\text { PUNK BROS } \\
\text { ALDRICH W CO } \\
\text { STATE OF N J } \\
\text { S. SWITLICK }\end{array}$ & $\begin{array}{l}\text { PUNK DEEP WELL } \\
\text { ALDRICH W CO } 2 \\
\text { ALLAIRE S P GZ } \\
\text { OIL TEST WELL } \\
\text { TEST WELL } 68-1\end{array}$ & $\begin{array}{r}140 \\
150 \\
30 \\
110 \\
120\end{array}$ & $\begin{array}{l}1964 \\
1960 \\
1967 \\
1968\end{array}$ & $\begin{array}{r}952 \\
440 \\
1029 \\
5000 \\
404\end{array}$ & $\begin{array}{l}-4 \\
-320 \\
-482 \\
-250 \\
-172\end{array}$ & $\begin{array}{r}84 \\
124 \\
90 \\
156 \\
100\end{array}$ & $\begin{array}{l}28 \\
34 \\
44 \\
24 \\
40\end{array}$ & $\begin{array}{l}176 \\
326 \\
172 \\
-\infty\end{array}$ \\
\hline
\end{tabular}


Table 2.--Stratigraphic control data--Continued

\begin{tabular}{|c|c|c|c|c|c|c|c|c|c|c|}
\hline $\begin{array}{l}\text { MAP } \\
\text { NO }\end{array}$ & LOCATION & OWNER & $\begin{array}{l}\text { LOCAL } \\
\text { NELLL } \\
\text { NUMBER }\end{array}$ & $\begin{array}{l}\text { ALTI- } \\
\text { TUDE- } \\
\text { OF LSD } \\
\text { (FT) }\end{array}$ & $\begin{array}{l}\text { DATE } \\
\text { DRILLED } \\
\text { (YEAR) }\end{array}$ & $\begin{array}{l}\text { WELL } \\
\text { DEPTH } \\
\text { (FT) }\end{array}$ & $\begin{array}{l}\text { ALTITUDE } \\
\text { OF TOP } \\
\text { OF } \\
\text { ENGLISHTOWN } \\
\text { FORMATION }\end{array}$ & $\begin{array}{l}\text { THICKNESS } \\
\text { OF } \\
\text { ENGLISHTOWN } \\
\text { FORMATION } \\
\text { (FT) }\end{array}$ & $\begin{array}{c}\text { THICKNESS } \\
\text { OF } \\
\text { OVERLYING } \\
\text { CONFINING } \\
\text { LAYER } \\
\text { (FT) }\end{array}$ & $\begin{array}{c}\text { THICKNESS } \\
\text { OF } \\
\text { UNDERLYING } \\
\text { CONFINING } \\
\text { LAYER } \\
\text { (FT) }\end{array}$ \\
\hline $\begin{array}{l}23 S \\
24 S \\
25 S \\
26 S \\
27 S\end{array}$ & $\begin{array}{l}400454 N 0740414.1 \\
400319 N 0741957.1 \\
400300 N 0743517.1 \\
400256 N 0744111.1 \\
400210 N 0740310.2\end{array}$ & $\begin{array}{l}\text { PT PLEASANT W D } \\
\text { GLIDDEN-DURKEE } \\
\text { US AIR FORCE } \\
\text { WM G HELIS } \\
\text { OCEAN CO } W\end{array}$ & $\begin{array}{l}\text { PPWD } 5 \\
\text { SCM } 3 \\
\text { MCGUIRE B } \\
\text { STOCK FARM } 3 \\
\text { MANTOLOKING } 7\end{array}$ & $\begin{array}{r}18 \\
105 \\
126 \\
70 \\
10\end{array}$ & $\begin{array}{l}1960 \\
1962 \\
1960 \\
1962 \\
1960\end{array}$ & $\begin{array}{r}1342 \\
1728 \\
835 \\
372 \\
1369\end{array}$ & $\begin{array}{l}-705 \\
-402 \\
-112 \\
+2 \\
-854\end{array}$ & $\begin{array}{l}158 \\
166 \\
50 \\
50 \\
180\end{array}$ & $\begin{array}{l}42 \\
62 \\
80 \\
35 \\
38\end{array}$ & $\begin{array}{l}188 \\
162 \\
178 \\
172 \\
202\end{array}$ \\
\hline $\begin{array}{l}28 \mathrm{~S} \\
29 \mathrm{~S} \\
30 \mathrm{~S} \\
31 \mathrm{~S} \\
32 \mathrm{~S}\end{array}$ & $\begin{array}{l}400138 N 0743753.1 \\
400129 N 0743656.1 \\
400115 N 0744009.1 \\
400105 N 0742244.1 \\
400046 N 0741838.1\end{array}$ & $\begin{array}{l}\text { US AR:AY } \\
\text { US ARMY } \\
\text { WM G HELIS } \\
\text { US NAVY } \\
\text { LAKEHURST WO }\end{array}$ & $\begin{array}{l}\text { FORT DIX } 3 \\
\text { FORT DIX } 2 \\
\text { STOCK FARM SO } \\
\text { LAKE NAS } 32 \\
1\end{array}$ & $\begin{array}{r}172 \\
131 \\
90 \\
100 \\
65\end{array}$ & $\begin{array}{l}-\overline{1941} \\
\overline{1964} \\
1928\end{array}$ & $\begin{array}{r}869 \\
1051 \\
498 \\
1583 \\
1035\end{array}$ & $\begin{array}{l}-130 \\
-155 \\
-96 \\
-418 \\
-559\end{array}$ & $\begin{array}{r}54 \\
70 \\
52 \\
152 \\
148\end{array}$ & $\begin{array}{l}58 \\
58 \\
56 \\
56 \\
96\end{array}$ & $\begin{array}{l}230 \\
162 \\
170 \\
170 \\
190\end{array}$ \\
\hline $\begin{array}{l}33 \mathrm{~S} \\
34 \mathrm{~S} \\
35 \mathrm{~S} \\
36 \mathrm{~S} \\
37 \mathrm{~S}\end{array}$ & $\begin{array}{l}400021 N 0744737.1 \\
400009 N 0740337.1 \\
395938 N 0743742.1 \\
395930 N 0741421.1 \\
395830 N 0744803.1\end{array}$ & $\begin{array}{l}\text { ACME FOOD STORE } \\
\text { OCEAN CO W C } \\
\text { US ARMY FT DIX } \\
\text { TOMS R CHEM CO } \\
\text { BROWN CO }\end{array}$ & $\begin{array}{l}1 \\
\text { NORMANDY } 4 \\
\text { FORT DIX } 6 \\
\text { TOMS R } 84 \\
\text { TEST } 1\end{array}$ & $\begin{array}{r}62 \\
8 \\
160 \\
66 \\
40\end{array}$ & $\begin{array}{l}1956 \\
1967 \\
1970 \\
1968 \\
1961\end{array}$ & $\begin{array}{r}545 \\
1500 \\
1140 \\
1480 \\
355\end{array}$ & $\begin{array}{r}42 \\
-924 \\
-232 \\
-711 \\
-41\end{array}$ & $\begin{array}{r}74 \\
176 \\
28 \\
148 \\
60\end{array}$ & $\begin{array}{r}34 \\
180 \\
40 \\
66 \\
25\end{array}$ & $\begin{array}{l}142 \\
214 \\
196 \\
180\end{array}$ \\
\hline $\begin{array}{l}38 \mathrm{~S} \\
39 \mathrm{~S} \\
40 \mathrm{~S} \\
41 \mathrm{~S} \\
42 \mathrm{~S}\end{array}$ & $\begin{array}{l}395808 N 0740416.1 \\
395721 N 0744821.1 \\
395720 N 0744822.1 \\
395524 N 0745025.1 \\
395122 N 074.3017 .1\end{array}$ & $\begin{array}{l}\text { LAVALLETTE W. D } \\
\text { LUMBERTON L W S } \\
\text { LUMBERTON L W } S \\
\text { US GEOL SURVEY } \\
\text { US GEOL SURVEY }\end{array}$ & $\begin{array}{l}\text { LAVALLETTE } 4 \\
\text { LLWS } 3 \\
\text { LLWS } 2 \\
\text { MEDFORD } 1 \\
\text { BUTLER PLACE } 1\end{array}$ & $\begin{array}{r}5 \\
10 \\
10 \\
70 \\
130\end{array}$ & $\begin{array}{l}1960 \\
1960 \\
1960 \\
1963 \\
1964\end{array}$ & $\begin{array}{r}1515 \\
400 \\
359 \\
410 \\
2117\end{array}$ & $\begin{array}{r}-946 \\
-90 \\
-90 \\
-112 \\
-684\end{array}$ & $\begin{array}{r}178 \\
80 \\
80 \\
84 \\
68\end{array}$ & $\begin{array}{r}190 \\
28 \\
28 \\
28 \\
18\end{array}$ & $\begin{array}{l}-\overline{1} \\
152 \\
152 \\
128 \\
294\end{array}$ \\
\hline $43 \mathrm{~S}$ & 394829 N0740535.3 & US GEOL SURVEY & IS BEACH 3 & 8 & 1962 & 2756 & -1390 & 152 & $=$ & $-\infty$ \\
\hline
\end{tabular}


The Englishtown Formation is exposed in the western part of the New Jersey Coastal Plain along a northeast-southwest trending zone extending from Raritan Bay to Delaware Bay (fig. 1). The formation dips gently from 30 to $50 \mathrm{ft} / \mathrm{mi}$ (feet per mile) $[5.7$ to $9.5 \mathrm{~m} / \mathrm{km}$ (meters per kilometer)] toward the southeast. The top of the formation is 700 to $800 \mathrm{ft}$ (213 to $243 \mathrm{~m}$ ) below sea leve1 in northeastern Ocean County (fig. 4, table 2).

The Englishtown conformably overlies the Woodbury Clay in the northern part of the New Jersey Coastal Plain and the Merchantville Formation farther to the south (Owens and Minard, 1970). The transitional contact between the Woodbury and the Englishtown "is characterized by a gradual increase in sand-sized quartz and a decrease in silt and clay" (Owens and Soh1, 1969, p. 244). The Englishtown Formation along its outcrop in the northern part of the Coastal Plain is typically a series of 1ight-gray to white thin cross-stratified fine- to medium-grained lignitic quartz sand beds intercalated with thin beds of dark-gray sandy silty clay and clayey silt. A marine and marginal marine origin has been established for parts of the Englishtown, especially along its outcrop south of Trenton. The internal structure of the Englishtown indicates an alluvial origin for the formation exposed between Trenton and Raritan Bay (Owens and Soh1, 1969, p. 245); in the vicinity of Raritan Bay a shallow-water to beach-complex environment of deposition is suggested by Minard (1969) and Seaber (1965).

The formation in the subsurface in northern, northwestern, and western Monmouth County seems to retain most of the lithologic characteristics displayed in outcrop. However, along a line extending roughly from Long Branch westward to the Freehold area and then southwest through extreme northwestern Ocean County, the Englishtown can be subdivided into two or three ill-defined thick dominantly sandy zones separated by one or two indistinct silty zones, which range in thickness from about 5 to $15 \mathrm{ft}$ $(1.5$ to $4.6 \mathrm{~m})$. This Iithologic subdivision can be traced downdip into southeastern Monmouth County and northern and eastern Ocean County, where the formation can be subdivided into three distinct lithologic units over an area extending from north of Lakewood east to Point Pleasant, south to Toms River, and southwest into east-central Burlington County (fig. 5). The upper and lower units consist of light-colored fine- to very fine-grained silty lignitic quartz sand with thin interbeds of dark sandy silt. These units are separated by a thick sequence of dark-gray sandy and clayey lignitic silt beds. The uppermost sand pinches out, apparently grading laterally into the silty lithofacies somewhere between Mantoloking and Normandy Beach and between Toms River and Lavallette. Farther southeast at Island Beach State Park the very fine-grained silty sand to sandy lithofacies predominates.

Seaber (1965) restricted the name Englishtown Formation to the quartz sand lithofacies, as described in outcrop, limiting the name Englishtown to a distinctive water-bearing rock-stratigraphic unit. However, Owens and Soh1 (1969) and Owens, Minard, Soh I, and Mello (1970) include more than one 


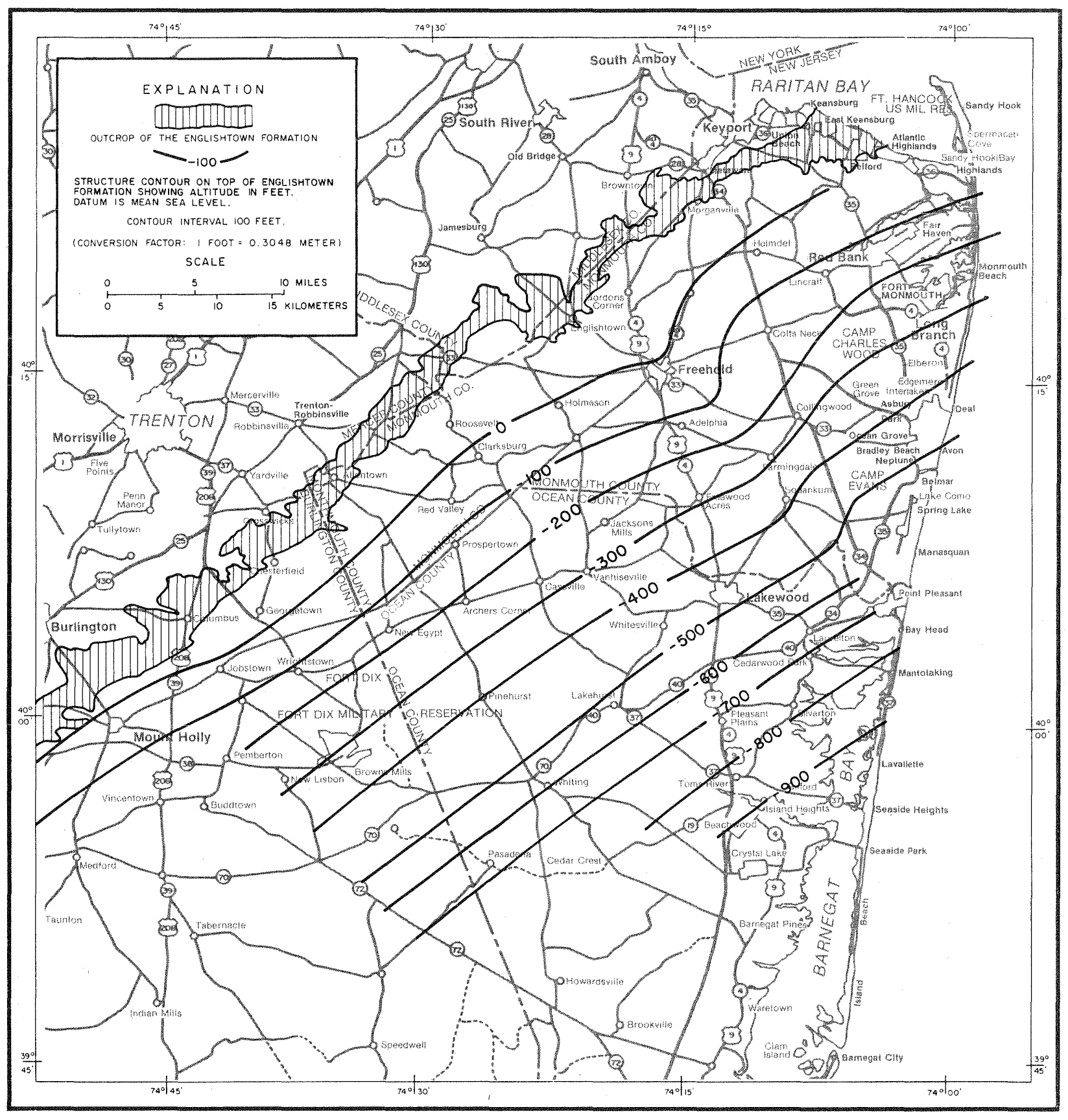

FIGURE 4. - -STRUCTURE CONTOURS OF THE TOP OF THE ENGLISHTOWN FORMATION IN MONMOUTH AND NORTHERN OCEAN COUNTIES, N.J. 


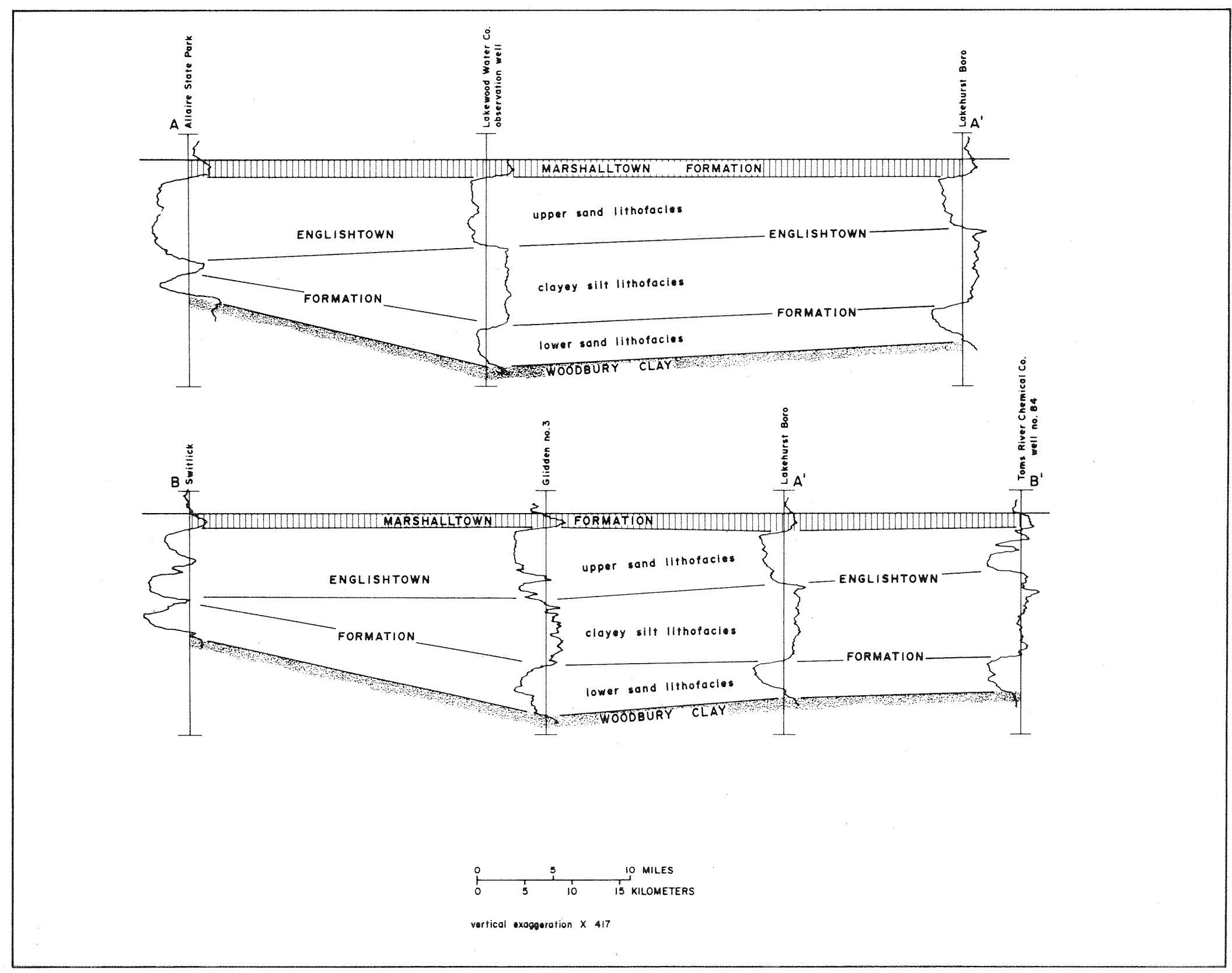

FIGURE 5. --CROSS SECTIONS A-A' AND B-B" SHOWING THE SAND AND CLAYEY SILT LITHOFACIES ON NATURAL GAMMA RADIATION LOGS OF THE ENGLISHTOWN FORMATION IN NORTHERN OCEAN COUNTY, N.J. (LOCATION OF CROSS-SECTION SHOWN ON FIGURE 3.) 
lithofacies in the formation. This report follows the usage of Owens and Soh1 and includes more than one lithofacies in the Englishtown. The lowermost sand in the subsurface of Ocean County, previously not recognized as part of the Englishtown, can be traced northward into the more typical Englishtown sequence in Monmouth County. The middle silty sequence is included in the formation because of its stratigraphic position between the two sand units; it is probably continuous with one of the silty zones observed in the subsurface of central Monmouth County.

The thickness of the Englishtown along its outcrop in the northern New Jersey Coastal Plain ranges from about $140 \mathrm{ft}(43 \mathrm{~m})$ near Raritan Bay to about $50 \mathrm{ft}(15 \mathrm{~m})$ near Trenton. The formation averages about $100 \mathrm{ft}(30 \mathrm{~m})$ thick in the subsurface throughout most of central Monmouth County. It gradually thickens to about $160 \mathrm{ft}(49 \mathrm{~m})$ in northern Ocean County and attains a maximum thickness of more than $200 \mathrm{ft}(61 \mathrm{~m})$ in the Toms River area of east-central Ocean County (fig. 6, table 2). Figures 7, 8, and 9 show the thickness of each of the three units into which the Englishtown can be subdivided in southeastern Monmouth County and northern Ocean County. Figure 5 shows these units in cross section. The upper sand unit thins southeastward from a maximum thickness of more than $80 \mathrm{ft}(24 \mathrm{~m})$ in northern Ocean County to less than $40 \mathrm{ft}(12 \mathrm{~m})$ near Toms River and about $20 \mathrm{ft}(6 \mathrm{~m})$ at Mantoloking. This 1ithofacies is absent from the section at Island Beach. The middle silt sequence thickens southeastward from about $20 \mathrm{ft}(6 \mathrm{~m})$, where it can be clearly identified in northern Ocean County and southeastern Monmouth County, to more than $130 \mathrm{ft}(39 \mathrm{~m})$ in the Toms River-Lavallette area. The lower sand had an average thickness of between 30 and $40 \mathrm{ft}(9$ and $12 \mathrm{~m}$ ) in north-central Ocean County. The unit thickens slightly toward the southeast to a maximum of about $50 \mathrm{ft}(15 \mathrm{~m})$ at Toms River and Lavallette. It cannot readily be recognized in the section at Island Beach State Park.

The Marshalltown Formation, which overlies the Englishtown throughout the New Jersey Coastal Plain is a massive dark-greenish-black fine- to very fine-grained clayey glauconite-quartz sand and silt. The abrupt contact between the Marsha11town and Englishtown and the presence of reworked Englishtown material in the basal few feet of the Marshalltown suggest a disconformable relationship (Owens and Soh1, 1969). The formation is remarkably uniform in thickness along its entire outcrop in New Jersey, ranging from 10 to $20 \mathrm{ft}(3$ to $6 \mathrm{~m}$ ). The same uniformity is observed everywhere in the subsurface of the northern Coastal Plain of New Jersey.

The overlying Wenonah Formation is a poorly sorted dark silty very fine to fine sand. The contact with the underlying Marshalltown is gradational. The Wenonah obtains a maximum thickness in outcrop of about $70 \mathrm{ft}(21 \mathrm{~m})$ in the vicinity of Mount Holly, N.J. (Minard and others, 1964). It thins along the outcrop both to the northeast and southwest. Minard (1969, 1965) reports a thickness of 25 to $30 \mathrm{ft}(7.6$ to $9 \mathrm{~m})$ near Raritan Bay and 15 to $25 \mathrm{ft}$ $(4.5$ to $7.6 \mathrm{~m})$ in extreme southwestern New Jersey. A similar range in thickness is observed in the subsurface of the northern Coastal Plain of New Jersey, although accurate identification of the formation on geophysical logs is difficult. 


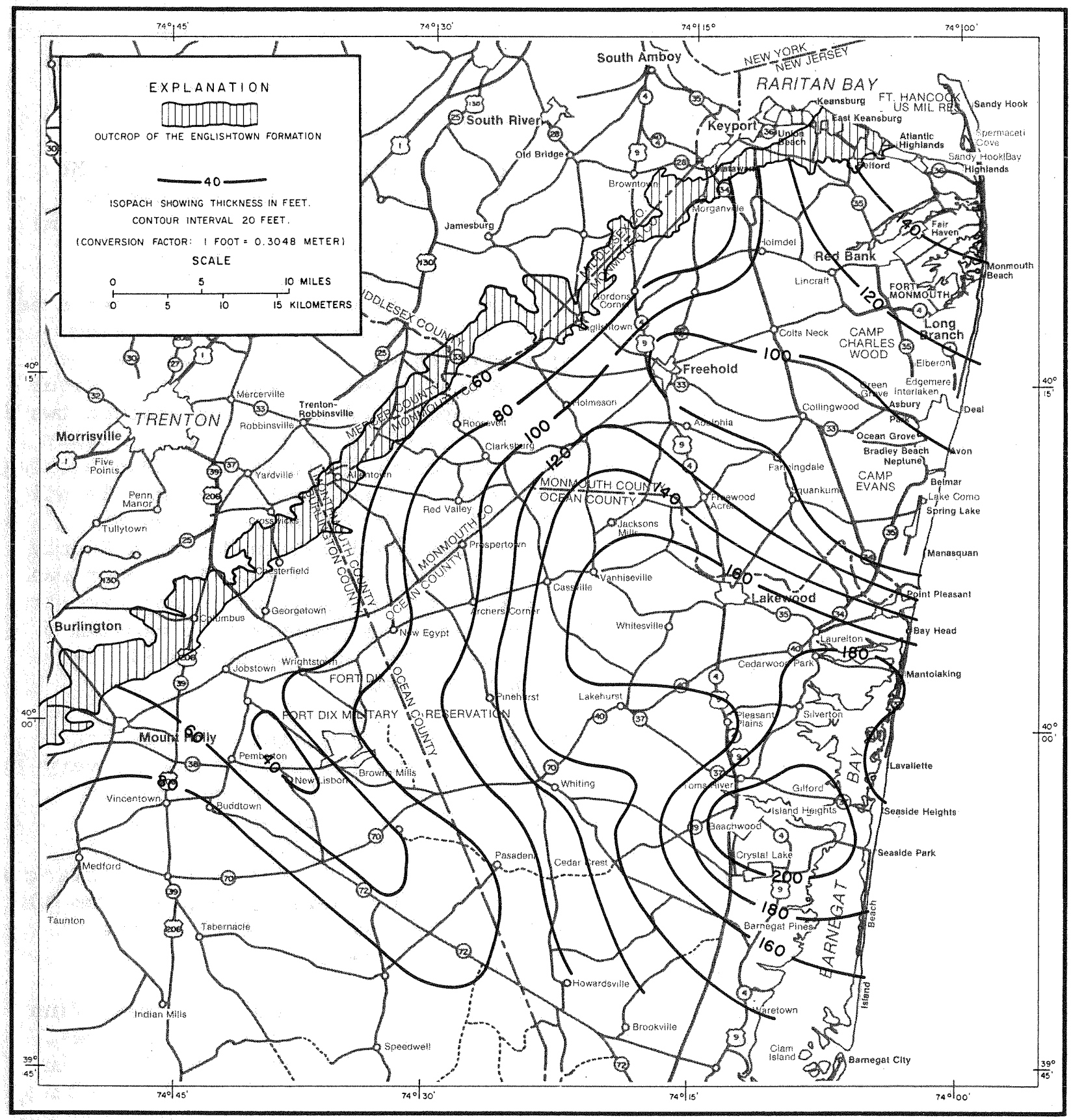

FIGURE 6. --THICKNESS OF THE ENGLISHTOWN FORMATION IN MONMOUTH AND NORTHERN OCEAN AND BURLINGTON COUNTIES, N.J. 


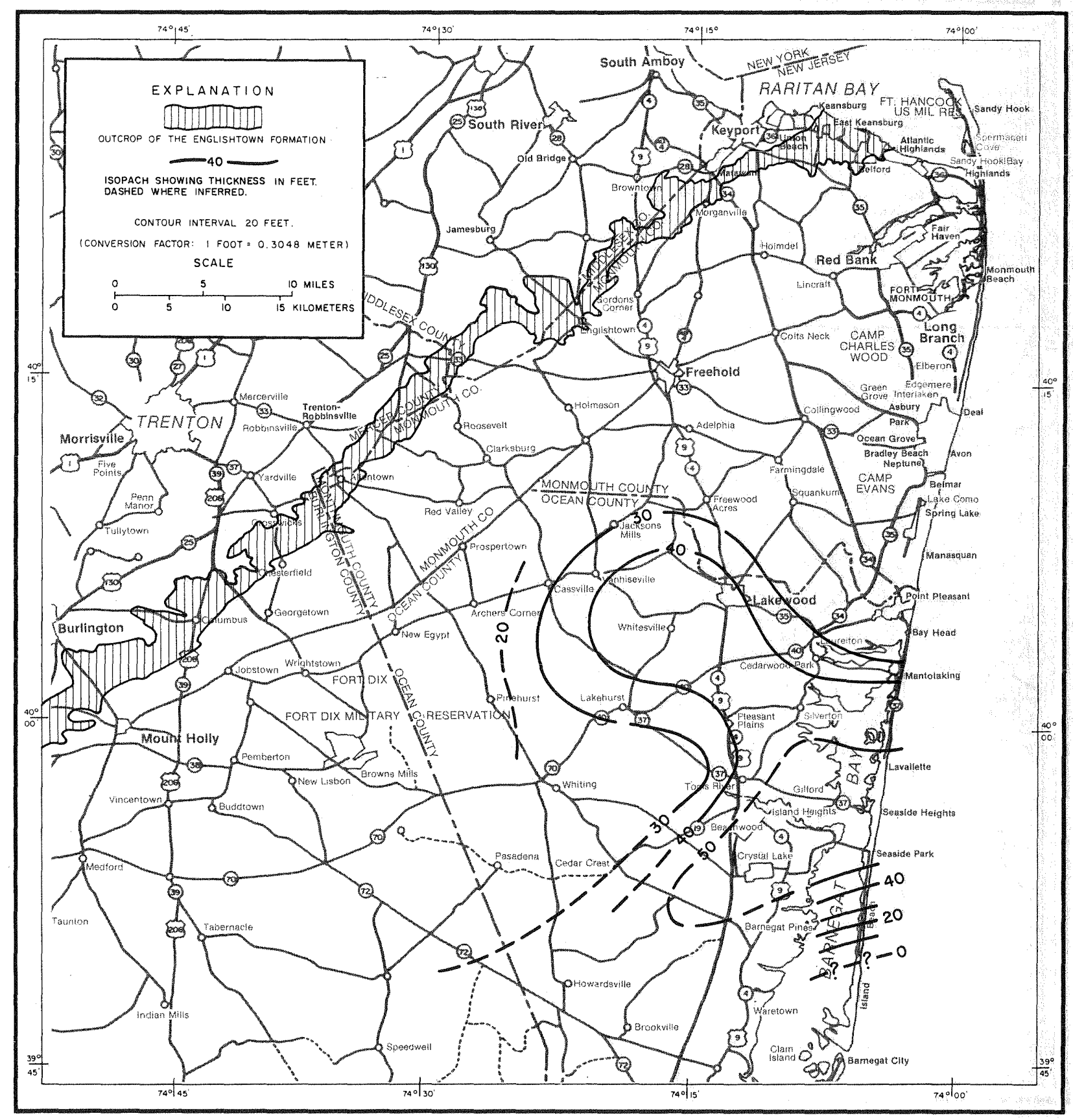

FIGURE 7. --THICKNESS OF THE LOWER SAND LITHOFACIES OF THE ENGLISHTOWN FORMATION IN NORTHERN OCEAN COUNTY, N.J. 


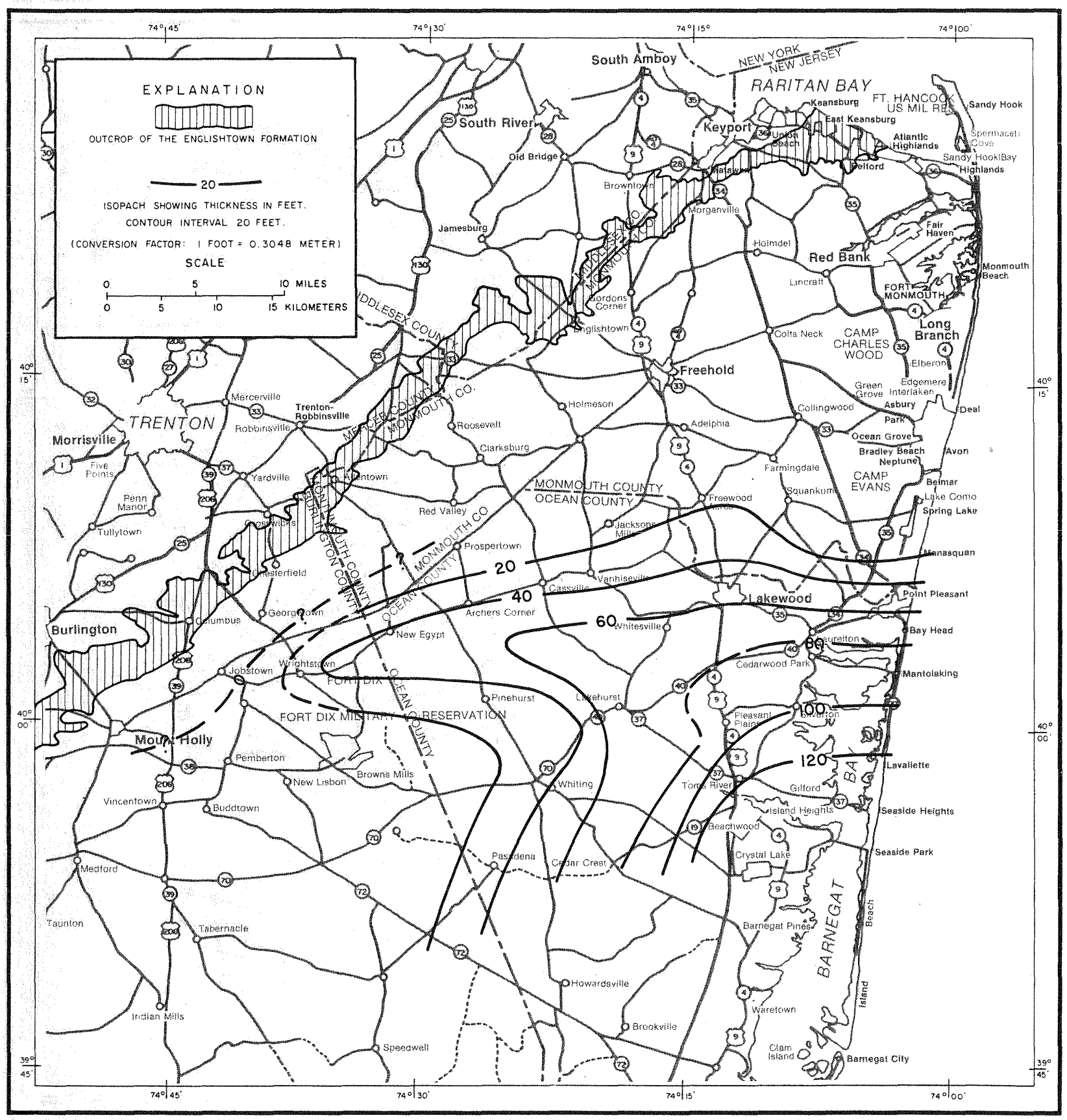

FIGURE 8. - THICKNESS OF THE CLAYEY SILT LITHOFACIES OF THE ENGLISHTOWN FORMATION IN NORTHERN OCEAN COUNTY, N.J. 


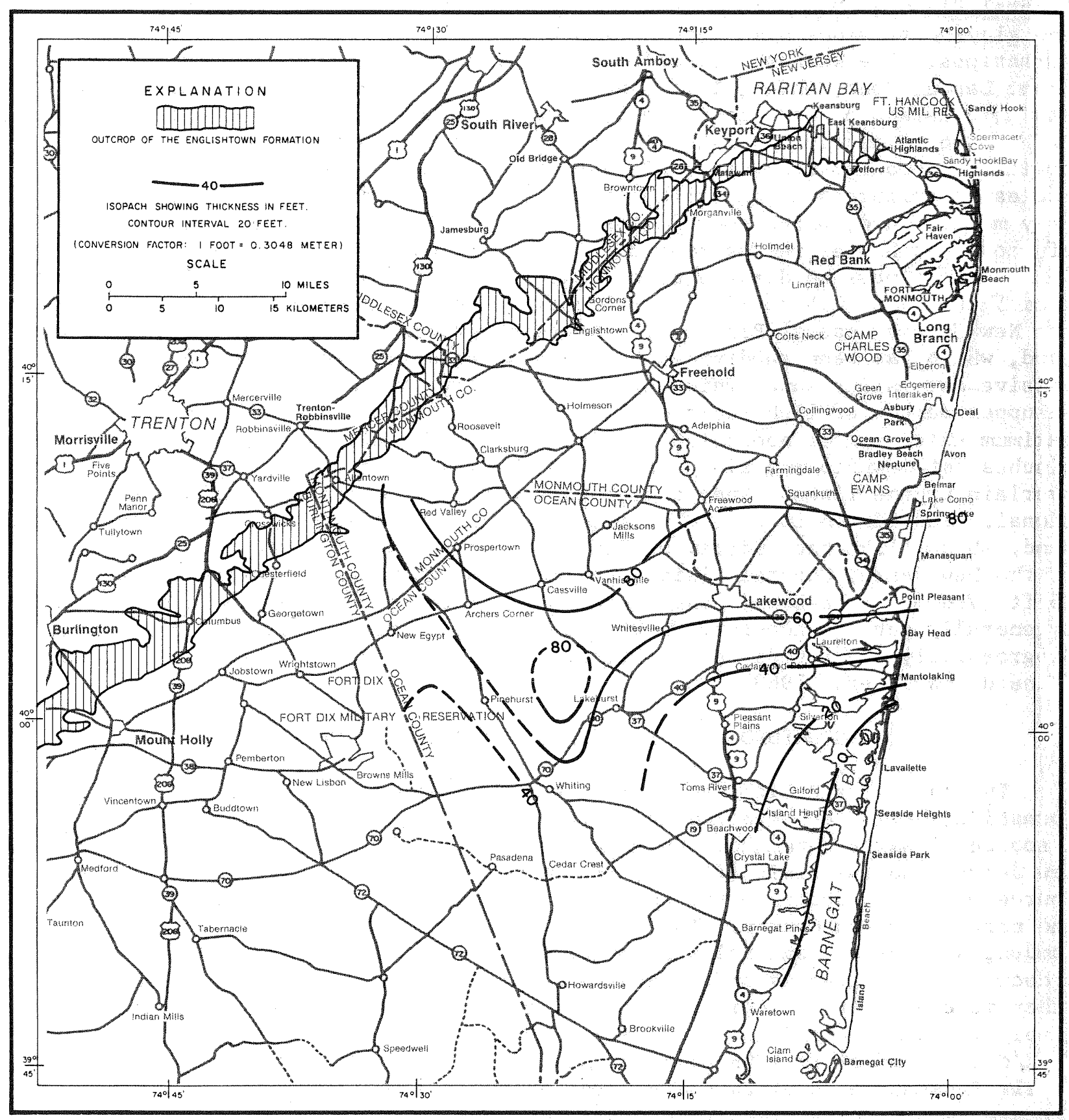

FIGURE 9. - THICKNESS OF THE UPPER SAND LITHOFACIES OF THE ENGLISHTOWN FORMATION IN NORTHERN OCEAN. COUNTY, N.J. 
Monmouth Group

Overlying the Wenonah Formation of the Matawan Group in the northern Coastal Plain of New Jersey is a sequence of medium- to coarse-grained quartz and glauconite sands named the Monmouth Group which is divided into four formations. The Wenonah Formation is the oldest and grades upward into the Mount Laurel Sand, which, like other coarse clastic units in the Coastal Plain, consists of more than one lithofacies along its outcrop. Near Raritan Bay the Mount Laurel consists of light-colored thin-bedded fine- to mediumgrained glauconite sand with thin interbeds of dark clay and silt. This facies interfingers along strike to the southwest with a massive-bedded darkgray medium sand, which constitutes the formation near Trenton. The thickness of the Mount Laure1 ranges from 20 to $70 \mathrm{ft}(6$ to $21 \mathrm{~m})$. The Navesink Formation, a massive dark-colored clayey glauconite sand ranging in thickness from 5 to $35 \mathrm{ft}(1.5$ to $10.6 \mathrm{~m})$, abruptly overlies the Mount Laurel throughout the New Jersey Coastal Plain. The Navesink grades upward into the Red Bank Sand, which has been subdivided into two members; a lower member of dominantly massive dark silty sand, which grades laterally into a glauconitic sand, and an upper member of 1ight-colored fine to coarse sand. The Red Bank has a maximum thickness of about $130 \mathrm{ft}(39.6 \mathrm{~m})$ in the Raritan Bay area, but pinches out downdip and along strike to the southwest. The Red Bank is overlain by the Tinton Sand; the contact between the two formations is gradationa1. The Tinton is a fine to medium glauconite-quartz to quartz-glauconite sand, which, like the underlying Red Bank, occurs only in the northern part of the New Jersey Coastal Plain. Its maximum thickness in outcrop is about $25 \mathrm{ft}(7.6 \mathrm{~m})$. The top of the Cretaceous section in New Jersey is marked by a generally subtle unconformity with the basal Tertiary sediments overlapping progressively lower beds in the Cretaceous section from northeast to southwest (Minard and others, 1969).

\section{GEOHYDROLOGY OF THE ENGLISHTOWN AQUIFER SYSTEM}

The quartz sand 1ithofacies (two units shown on fig. 5) of the Englishtown Formation, hereafter referred to as the Englishtown aquifer, are utilized as a source of water throughout an area of about $1,100 \mathrm{mi}^{2}\left(2,849 \mathrm{~km}^{2}\right)$ of the New Jersey Coastal Plain (fig. 1) (Seaber, 1965, p. B16). It is an important source of water supply in the northeastern Coastal Plain in Monmouth County and northern Ocean County. The aquifer is less developed in Burlington, Camden, Gloucester, and Salem Counties to the southwest, largely because of a decrease in thickness and water-yield capabilities, and the presence of other more productive aquifers. Total ground-water withdrawals for public supply in Monmouth and northern Ocean Counties increased from about 5.5 $\mathrm{MgaI} / \mathrm{d}\left(0.24 \mathrm{~m}^{3} / \mathrm{s}\right)$ in 1959 to about $9.5 \mathrm{Mgal} / \mathrm{d}\left(0.4 \mathrm{~m}^{3} / \mathrm{s}\right)$ in 1970 . Water levels in some parts of this area are declining 8 to $12 \mathrm{ft}(2.4$ to $3.6 \mathrm{~m})$ per year and have declined more than $100 \mathrm{ft}(30 \mathrm{~m})$ near centers of pumping between 1959 and 1970 (fig. 10).

The Englishtown aquifer, together with the underlying and overlying confining beds, constitute the Englishtown aquifer system. This system is, 


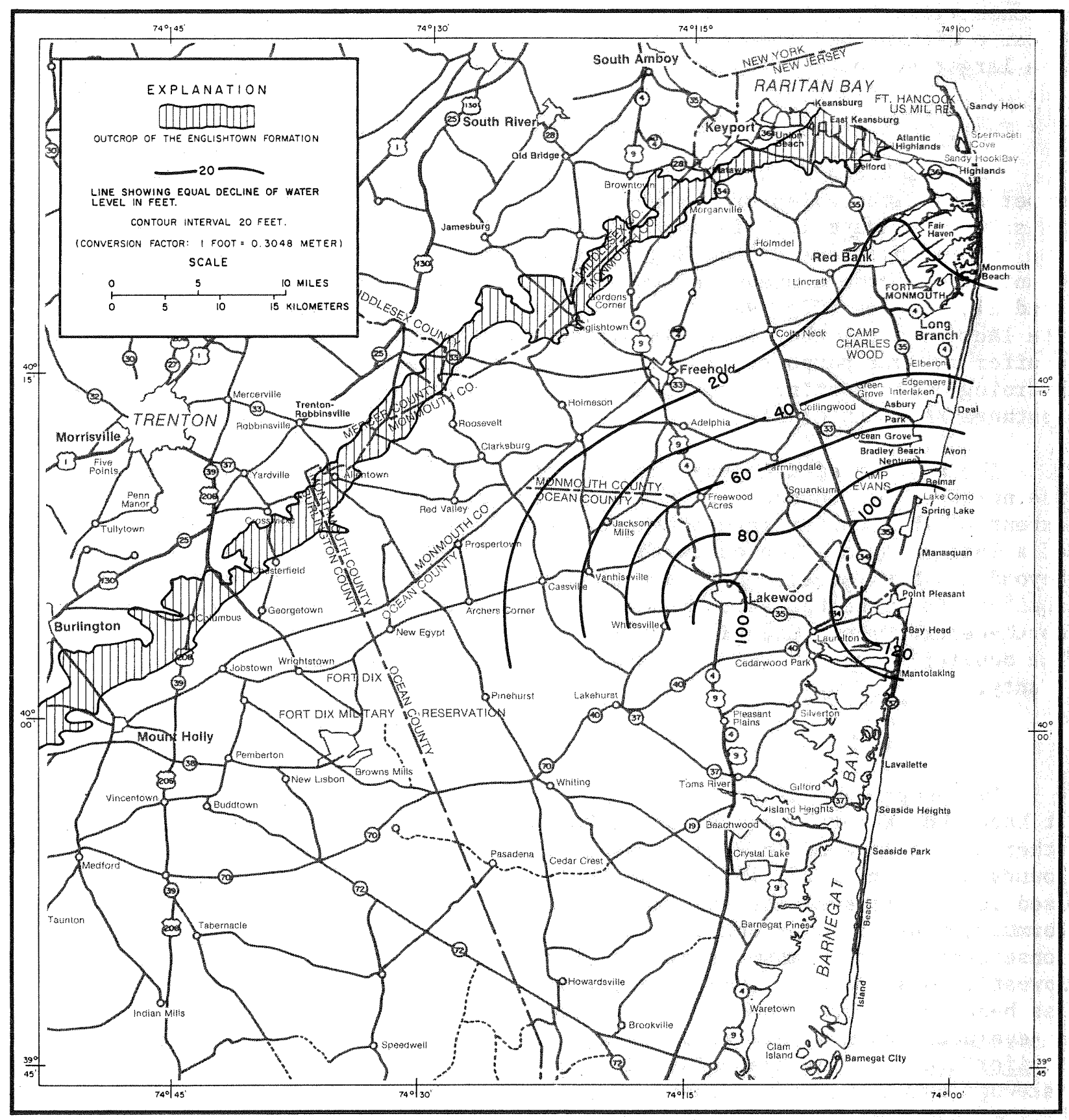

FIGURE 10. -DECLINE IN WATER LEVEL BETWEEN JANUARY 1959 AND NOVEMBER 1970 IN THE ENGLISHTOWN AQUIFER IN MONMOUTH AND NORTHERN OCEAN COUNTIES, N.J. 
in turn, a subsystem of the larger Coastal Plain aquifer system of New Jersey. The overlying confining bed, which includes the Marshalltown Formation and part of the Wenonah Formation, provides the interconnection between the Englishtown subsystem and the overlying part of the larger system. The Merchantville Formation and Woodbury Clay, which together constitute the lower confining bed, perform the same function with respect to that part of the larger system underlying the Englishtown.

\section{Aquifer Geometry and Boundaries}

The thickness of the Englishtown aquifer in Monmouth County and the upper sand lithofacies of the aquifer in northern Ocean and Burlington Counties is shown in figure 11. Throughout most of Monmouth County the aquifer includes the entire thickness of the Englishtown Formation. In southeastern Monmouth County and northern Ocean and Burlington Counties, however, only the upper sand 1ithofacies (fig. 9) is included as part of the aquifer. Because of the lack of data, the lower sand lithofacies (fig. 7) is not included in the aquifer for the purposes of this study, even though it is 1ithologically and hydrologically continuous with the aquifer over some undefined area across southern Monmouth County.

The outcrop of the upper contact of the Englishtown Formation marks the northwestern boundary of the confined part of the aquifer. The southward extent of the aquifer into southern ocean County cannot be determined because of a lack of data. The eastward extent and thickness trends of the aquifer, beyond the New Jersey coast, are also unknown. The thickest parts of the aquifer are in northeastern Monmouth County and south-central Monmouth and north-central Ocean Counties, where it is more than $120 \mathrm{ft}(36 \mathrm{~m})$ thick. The aquifer generally thins toward the south into central and eastern Ocean County.

\section{Aquifer Coefficients}

Two pumping tests of the Englishtown aquifer have been conducted; one at Lakewood in north-central Ocean County on May 14 and 15, 1959, and the other near Allenwood in Wall Township in extreme southeastern Monmouth County on November 28, 1959. The Theis (1935) nonequilibrium formula was used in 1959 to evaluate the data collected during both of these tests. This formula, however, does not take into account the leaky nature of the aquifer. Consequently, the transmissivity ascribed to the Englishtown by previous investigators (Seaber, 1965; Rush, 1968; Anderson and Appe1, 1969) generally has been too large. The data collected during the two pumping tests were re-evaluated during this study using the Hantush (1960) modified leaky aquifer theory. The transmissivity computed from the drawdown data at Lakewood using the Theis equation was $1,300 \mathrm{ft}^{2} /$ day (square feet per day) $\left[121 \mathrm{~m}^{2} /\right.$ day (square meters per day)]. This compares with a transmissivity of $1,100 \mathrm{ft}^{2} /$ day $\left(102 \mathrm{~m}^{2} / \mathrm{day}\right)$ computed from drawdown data with the Hantush modified equations. The storage coefficients computed with the Theis equation were $2.7 \times 10^{-4}$. These compare with a storage coefficient of $2.2 \mathrm{x}$ $10^{-4}$ computed with the modified leaky aquifer equations. 


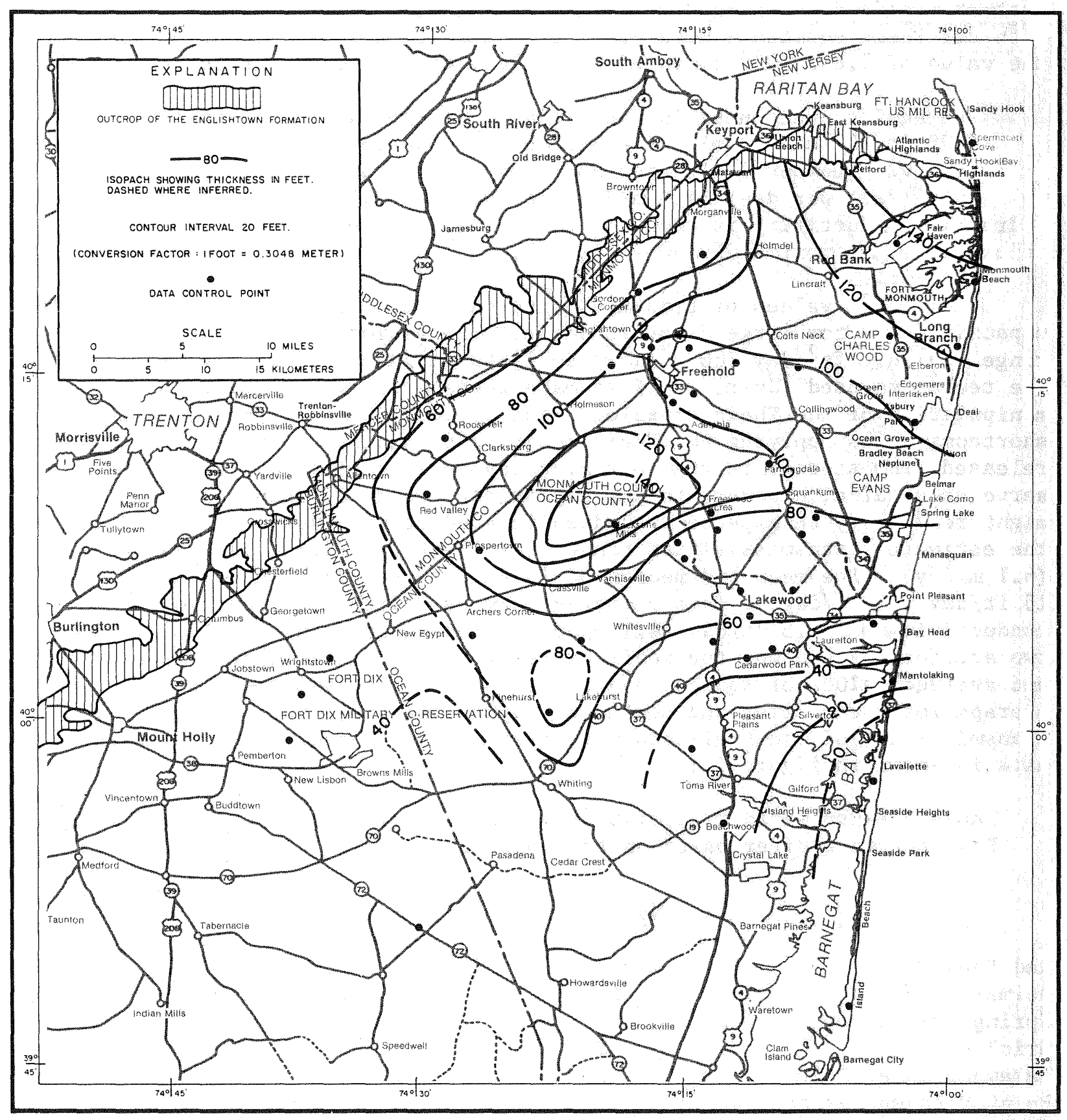

FIGURE 11. --THICKNESS OF THE ENGLISHTOWN AQUIFER IN MONMOUTH COUNTY AND OF THE UPPER SAND LITHOFACIES OF THE ENGLISHTOWN AQUIFER IN NORTHERN OCEAN AND BURLINGTON COUNTIES, N.J. 
The drawdown and recovery data obtained during the test at Allenwood were used in the Theis equation to compute transmissivities of $1,200 \mathrm{ft}^{2} / \mathrm{day}$ $\left(111 \mathrm{~m}^{2} /\right.$ day) and $1,300 \mathrm{ft}^{2} /$ day $\left(121 \mathrm{~m}^{2} /\right.$ day $)$. These same drawdown data were used to compute a transmissivity of $1,100 \mathrm{ft}^{2} /$ day $\left(102 \mathrm{~m}^{2} /\right.$ day $)$ with the Hantush modified leaky aquifer equations. The storage coefficients computed with the Theis equations were $8.8 \times 10^{-5}$ and $8.3 \times 10^{-5}$ which are close to the value of $7.6 \times 10^{-5}$ computed with the modified leaky aquifer equations.

The aquifer thickness in the vicinity of the Lakewood test is between 70 and $75 \mathrm{ft}(21$ and $23 \mathrm{~m})$. The hydraulic conductivity, using the value of transmissivity computed with the modified leaky aquifer equations, is about $15 \mathrm{ft} /$ day (feet per day) [4.6 m/day (meters per day)]. At Allenwood the hydraulic conductivity is about $12 \mathrm{ft} /$ day $(4.6 \mathrm{~m} /$ day) based on an aquifer thickness of approximately $90 \mathrm{ft}(27 \mathrm{~m})$.

Additional values of transmissivity have been estimated using specific capacity data from large diameter wells. The estimated transmissivities range from $650 \mathrm{ft}^{2} /$ day $\left(60 \mathrm{~m}^{2} /\right.$ day) to $2,400 \mathrm{ft}^{2} /$ day $\left(223 \mathrm{~m}^{2} / \mathrm{day}\right)$ (table 3$)$. The technique used (Hurr, 1966) to make these estimates is based on a manipulation of the Theis equation. The approach suffers from the same shortcomings as applying the Theis equation to aquifer test data since water released from storage in the confining layers is neglected. The estimates serve as a guide, however, to the approximate range of transmissivity that might reasonably be expected. Hydraulic conductivity values obtained from the estimated transmissivities range from $11 \mathrm{ft} / \mathrm{day}(3.3 \mathrm{~m} / \mathrm{day})$ to $20 \mathrm{ft} / \mathrm{day}$ $(6.1 \mathrm{~m} / \mathrm{day})$. The mean and median of 15 values of hydraulic conductivity is $15 \mathrm{ft} /$ day $(4.5 \mathrm{~m} / \mathrm{day})$. This compares very well with the mean hydraulic conductivity of $13.5 \mathrm{ft} /$ day $(4.1 \mathrm{~m} /$ day $)$ computed from the results of the two aquifer tests using the modified leaky aquifer equations. The extreme and average values of aquifer hydraulic conductivity and specific storage for the aquifer and confining layers are given in table 4. The transmissivity of the Englishtown aquifer which is based on all available data is shown in figure 12 .

Table 3.--Estimated transmissivity and hydraulic conductivity of the Englishtown aquifer based on the specific capacity of selected wells

\begin{tabular}{|c|c|c|c|c|c|}
\hline & We11 No. & $\left(\mathrm{ft}^{2} / \mathrm{day}\right)^{\underline{\mathrm{T}}}$ & $\left(\mathrm{m}^{2} / \mathrm{day}\right)$ & (ft/day) & (m/day) \\
\hline Red Bank Boro & 2 & 2,400 & 223 & 17 & 5.2 \\
\hline Belmar Boro & 11 & 1,400 & 130 & 16 & 4.9 \\
\hline Spring Lake Boro & 3 & 960 & 99 & 12 & 3.6 \\
\hline Brielle Boro & 2 & 1,100 & 102 & 14 & 4.2 \\
\hline Lakewood Water Co. & 6 & 1,100 & 102 & 16 & 4.9 \\
\hline Point Pleasant Water Dept. & 1 & 740 & 69 & 12 & 3.6 \\
\hline do. & 2 & 900 & 84 & 15 & 4.6 \\
\hline do. & 3 & 750 & 70 & 12 & 3.6 \\
\hline Central RR of New Jersey & - & 1,100 & 102 & 19 & 5.8 \\
\hline Ocean County Water Co. & Bay Head 6 & 650 & 60 & 13 & 3.9 \\
\hline Lavoie Labs & - & 1,600 & 149 & 20 & 6.1 \\
\hline Frank Gumina & - & 1,900 & 176 & 17 & 5.2 \\
\hline Anthony Verange & - & 2,000 & 186 & 20 & 6.1 \\
\hline Laura Harding & - & 1,200 & 111 & 12 & 3.6 \\
\hline U.S. Army, Camp Evans & Bldg. 82 & 1,000 & 93 & 11 & 3.3 \\
\hline
\end{tabular}




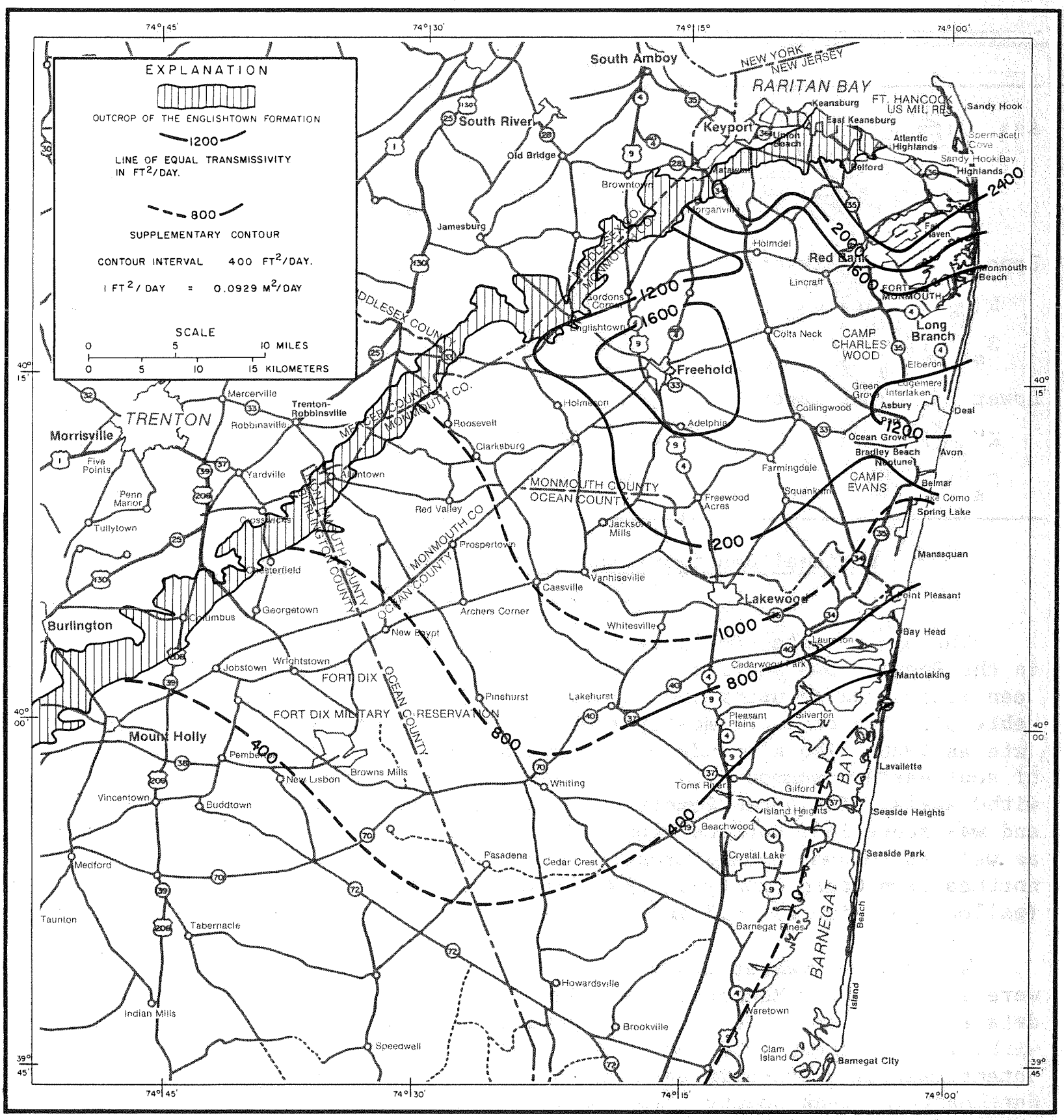

FIGURE 12. --TRANSMISSIVITY OF THE ENGLISHTOWN AQUIFER IN MONMOUTH AND NORTHERN OCEAN COUNTIES, N.J. 
Table 4.--Extreme and average values of hydraulic coefficients of the aquifer and confining layer

(K - hydraulic conductivity)

$\left(S_{S}-\right.$ specific storage)

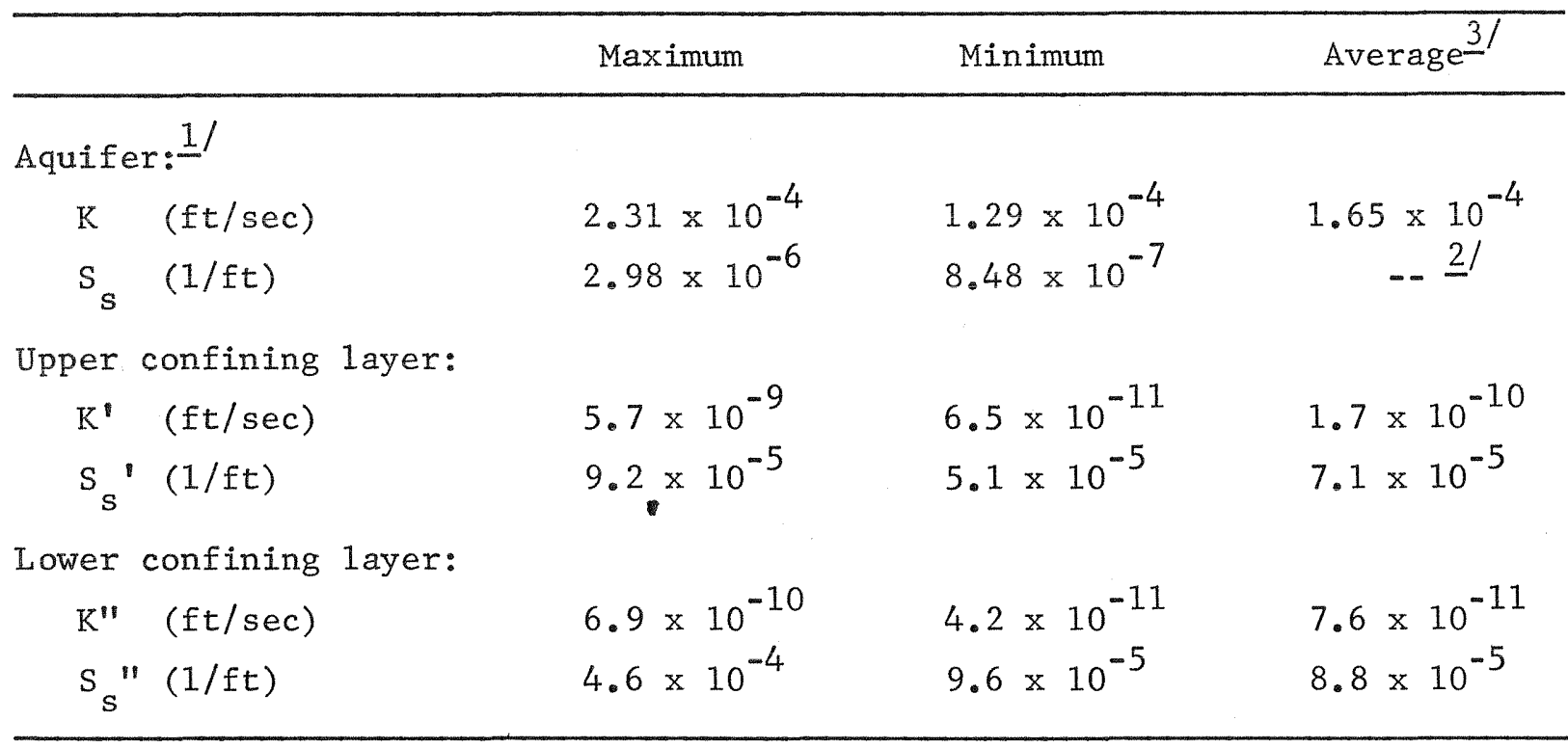

Regional Configuration of the Potentiometric Surface and Water-leve1 Trends

The approximate configuration of the prepumping potentiometric surface in the Englishtown aquifer in Monmouth, Ocean, and Burlington Counties has been reconstructed using the earliest available water-level data (fig. 13, table 5). The data are mostly from the period 1890-1900, but some are as late as 1920. The altitude of the surface in the Belmar-Spring Lake area of southeastern Monmouth County probably reflects the effects of pre-1900 withdrawals. The potentiometric surface was everywhere above sea level and was above land surface along the coastal areas south of Long Branch as well as in some inland areas. Several wells drilled at Lakewood in northeastern Ocean County in 1899 flowed between 100 and $150 \mathrm{gal} / \mathrm{min}$ (gallons per minute) $[6.3$ and $9.41 / \mathrm{s}$ (1iters per second)] at land surface.

Water-level measurements obtained in December 1958 and January 1959 were available for Monmouth and Ocean Counties (table 6). Well construction data are shown on table 7. It is apparent from these data that ground-water withdrawals between 1900 and 1959 caused a significant lowering of the potentiometric surface in eastern and southeastern Monmouth County and northeastern Ocean County (fig. 14). A decline of $40 \mathrm{ft}(12 \mathrm{~m})$ or more occurred over a wide area, and a decline of more than $100 \mathrm{ft}(30 \mathrm{~m})$ occurred

1/Calculated from aquifer test data

2/Insufficient field data

$3 /$ Harmonic mean values. 


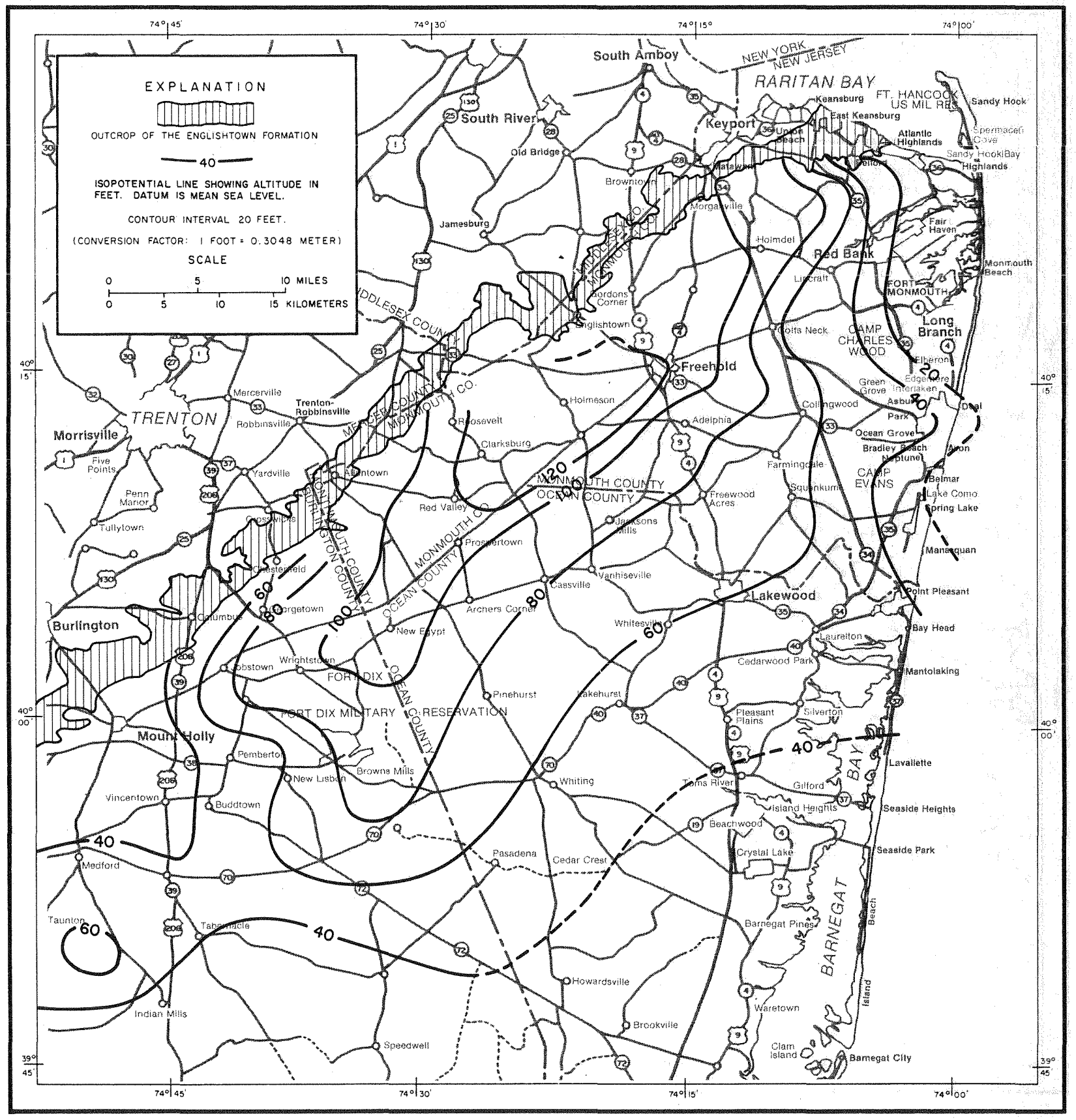

FIGURE 13. --ALTITUDE OF THE POTENTIOMETRIC SURFACE IN THE ENGL ISHTOWN AQUIFER ABOUT 1900 IN MONMOUTH AND NORTHERN OCEAN AND BURLINGTON COUNTIES, N.J. 


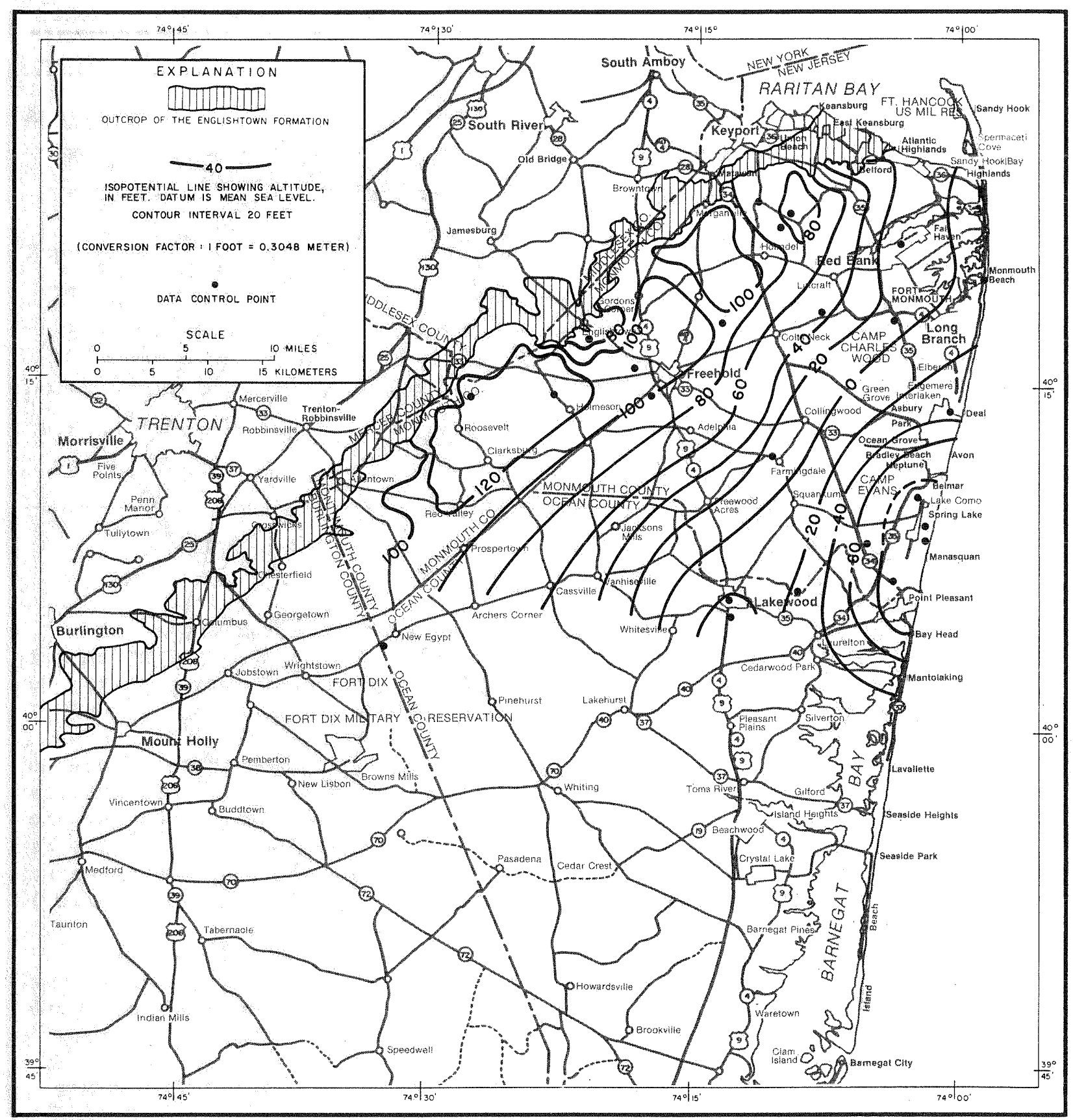

FIGURE 14. --ALTITUDE OF THE POTENTIOMETRIC SURFACE IN THE ENGLISHTOWN AQUIFER IN JANUARY 1959 IN MONMOUTH AND NORTHERN OCEAN COUNTIES, N.J. 
Table 5.--Water-level data used in constructing 1900 potentiometric surface map for the Englishtown aquifer

\begin{tabular}{|c|c|c|c|c|c|c|c|}
\hline $\begin{array}{l}\text { Map } \\
\text { no. }\end{array}$ & Location & Owner & $\begin{array}{c}\text { Local } \\
\text { we } 11 \\
\text { designation }\end{array}$ & $\begin{array}{l}\text { Altitude } \\
\text { of LSD } \\
\text { (ft) } \\
\text { (mean sea } \\
\text { leve1 } \\
\text { datum) }\end{array}$ & $\begin{array}{l}\text { Water } \\
\text { level } \\
\text { (ft) } \\
\text { (depth } \\
\text { below } \\
\text { lsd) }\end{array}$ & $\begin{array}{l}\text { Date } \\
\text { water } \\
\text { level } \\
\text { meas. }\end{array}$ & Remarks \\
\hline 1 & $402450 \mathrm{~N} 0740233.1$ & Charles Leonard & Leonard & 30 & 28 & 1897 & \\
\hline 2 & 402024 N0741009.1 & Unknown & Owner Unknown & 160 & 146 & 1900 & \\
\hline 3 & 402328 N0740055.1 & Vincent Lamarch & Lamarch & 4 & 0 & 1898 & \\
\hline 4 & 402226 N0740028. 1 & M C D Borden & Borden & 16 & 12 & 1897 & \\
\hline 5 & 402201 N0740152.1 & Rumson Improvmt & Rumson Imprvmt & 10 & 6 & 1904 & \\
\hline 6 & $402124 \mathrm{~N} 0735917.1$ & Dr Kimbal1 & Kimba11 & 12 & 9 & 1897 & \\
\hline 7 & 402111 N0740055.1 & Mr Lobb & Lobb & 45 & 38 & 1898 & \\
\hline 8 & 401959N0740440.1 & Town W Comm & Town W Commsrs & 18 & 15 & 1900 & \\
\hline 9 & $401942 N 0740230.1$ & Mcmahon \& Dean & Mcmahon \& Dean & 38 & 2 & 1899 & \\
\hline 10 & 401653 N0741721. 1 & Freehold W\&U Au & Freehold W\&U & 120 & 16 & 1890 & \\
\hline 11 & 401316 N0740142.1 & Ocean Grove AS & Ocean Grove AS & 20 & +28 & 1883 & \\
\hline 12 & $400817 \mathrm{~N} 0740223.1$ & Beach H Sea Grt & Beach House SG & 11 & +13 & 1895 & \\
\hline 13 & $400547 \mathrm{~N} 0741329.1$ & Laure1 Hoté1 & Laure1 Hote1 & 50 & +17 & 1884 & \\
\hline 14 & 400507 N0 0741247.1 & Lakewood W Co & Lakewood W Co & 30 & +20 & 1899 & \\
\hline 15 & $400434 \mathrm{~N} 0740241.1$ & Beacon-by-Sea & Beacon-by-Sea & 10 & +36 & 1896 & \\
\hline 16 & $400233 \mathrm{~N} 0740300.1$ & Mantoloking & Mantoloking & 10 & +42 & 1896 & \\
\hline 17 & $395814 \mathrm{~N} 0743438.1$ & Mr Reilly & Reilly & 20 & $\mathrm{~F}$ & $-\infty$ & Flowing \\
\hline 18 & 395749 N0743100.1 & J J White Co & J J White Co & 95 & 5 & 1914 & \\
\hline
\end{tabular}


Table 6.--Yield and water-level data for wells developed in the Englishtown aquifer in Monmouth and Ocean Counties

\begin{tabular}{|c|c|c|c|c|c|c|c|c|c|c|c|c|c|}
\hline $\begin{array}{l}\text { MAP } \\
\text { NO }\end{array}$ & OWNER & $\begin{array}{l}\text { LOCAL } \\
\text { WELL } \\
\text { NUMBER }\end{array}$ & $\begin{array}{l}\text { ALTI- } \\
\text { TUDE- } \\
\text { OF LSD } \\
(F T)\end{array}$ & $\begin{array}{l}\text { YIELD } \\
(\text { GAL/MIN) }\end{array}$ & $\begin{array}{l}\text { DRAW } \\
\text { DOWN } \\
(F T)\end{array}$ & $\begin{array}{l}\text { PUMP ING } \\
\text { PERIOD } \\
\text { (HOURS) }\end{array}$ & $\begin{array}{l}\text { SPECIFIC } \\
\text { CAPACITY }\end{array}$ & $\begin{array}{l}\text { WATER } \\
\text { LEVEL } \\
\text { (FT) }\end{array}$ & $\begin{array}{l}\text { DATE } \\
\text { WATER } \\
\text { LEVEL } \\
\text { MEASURED }\end{array}$ & $\begin{array}{l}\text { WATER } \\
\text { LEVEL } \\
\text { (FT) }\end{array}$ & $\begin{array}{l}\text { DATE } \\
\text { WATER } \\
\text { LEVEL } \\
\text { MEASURED }\end{array}$ & $\begin{array}{l}\text { WATER } \\
\text { LEVEL } \\
\text { (FTi }\end{array}$ & $\begin{array}{l}\text { DATE } \\
\text { WATER } \\
\text { LEVEL } \\
\text { MEASURE }\end{array}$ \\
\hline $\begin{array}{l}1 \\
2 \\
3 \\
4 \\
5\end{array}$ & $\begin{array}{l}\text { L. BAHRENBURG } \\
\text { EDWARD LESKE } \\
\text { ATLAN HIGH W D } \\
\text { A W ZELINSKI } \\
\text { LILY TULIP CUP }\end{array}$ & $\begin{array}{l}\text { BAHRENBURG } 1 \\
\text { LESKE } 3 \\
\text { AHWD } 2 \\
1 \\
\text { LILY STAND BY }\end{array}$ & $\begin{array}{l}60 \\
25 \\
15 \\
80 \\
65\end{array}$ & $-\infty 5$ & $\begin{array}{r}6 \\
-6 \\
-14 \\
32\end{array}$ & $\frac{8}{--}$ & $\begin{array}{l}-\infty \\
0.8 \\
4.3 \\
--\end{array}$ & $\begin{array}{l}13 \\
10 \\
16 \\
26 \\
19\end{array}$ & $\begin{array}{r}1-52 \\
11-52 \\
-23 \\
8-63 \\
1-62\end{array}$ & 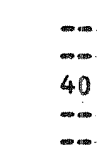 & $\begin{array}{c}-\infty \\
1-59 \\
-\infty\end{array}$ & $\begin{array}{l}-\infty \\
14 \\
-\infty\end{array}$ & $\begin{array}{c}= \\
11-70 \\
-- \\
-\infty\end{array}$ \\
\hline $\begin{array}{r}6 \\
7 \\
8 \\
9 \\
10\end{array}$ & $\begin{array}{l}\text { LILY TULIP CUP } \\
\text { LILY TULIP CUP } \\
\text { LAVOIE LAB } \\
\text { B EDUC MARLBORO } \\
\text { B EDUC MARLBORO }\end{array}$ & $\begin{array}{l}\text { LILY TULIP } 1 \\
\text { LILY TULIP } 2 \\
\text { LAVOIE LAB } 1 \\
\text { BOARD OF ED } 1 \\
\text { BOARD OF ED } 2\end{array}$ & $\begin{array}{r}65 \\
55 \\
180 \\
180 \\
--\end{array}$ & $\begin{array}{l}500 \\
-6 \\
170 \\
60 \\
150\end{array}$ & $\begin{array}{l}44 \\
32 \\
30 \\
18 \\
28\end{array}$ & $\begin{array}{r}8 \\
8 \\
19 \\
--\end{array}$ & $\begin{array}{l}11.4 \\
-.7 \\
5.7 \\
3.3 \\
5.4\end{array}$ & $\begin{array}{l}25 \\
26 \\
85 \\
70 \\
64\end{array}$ & $\begin{array}{r}2-62 \\
2-62 \\
10-48 \\
7-48 \\
9-67\end{array}$ & $\begin{array}{l}= \\
= \\
= \\
=\end{array}$ & $=$ & $\begin{array}{l}-\infty \\
= \\
-\infty\end{array}$ & $\begin{array}{l}-\infty \\
-\infty \\
-\infty\end{array}$ \\
\hline $\begin{array}{l}11 \\
12 \\
13 \\
14 \\
15\end{array}$ & $\begin{array}{l}\text { DONALD AHLERS } \\
\text { L F GRANDINETTI } \\
\text { JOSEPH STAVELA } \\
\text { GARDEN ST PKWY } \\
\text { RICHARD CARROLL }\end{array}$ & TELEGRAPH HILL & $\begin{array}{r}121 \\
70 \\
180 \\
234 \\
95\end{array}$ & $\begin{array}{r}10 \\
30 \\
12 \\
-15\end{array}$ & $\begin{array}{r}-- \\
28 \\
11 \\
--6\end{array}$ & $\begin{array}{l}-- \\
12 \\
--\end{array}$ & $\begin{array}{l}-- \\
1.1 \\
1.1 \\
2.5\end{array}$ & $\begin{array}{r}40 \\
35 \\
178 \\
-\quad 22\end{array}$ & $\begin{array}{r}5-64 \\
12-55 \\
5-51 \\
-5 \\
12-53\end{array}$ & $=$ & $\begin{array}{l}- \\
=- \\
= \\
=\end{array}$ & $\begin{array}{l}- \\
= \\
= \\
=\end{array}$ & $\begin{array}{l}= \\
=- \\
=\end{array}$ \\
\hline $\begin{array}{l}16 \\
17 \\
18 \\
19 \\
20\end{array}$ & $\begin{array}{l}\text { JOHN GARRISON } \\
U S \text { S ARMY } \\
\text { NEIL BPY } \\
F \text { \& F NURSERIES } \\
G \text { HUBENY }\end{array}$ & $\begin{array}{l}\text { NIKE BASE } \\
\text { FF NURSERIES } 1\end{array}$ & $\begin{array}{l}100 \\
305 \\
210 \\
135 \\
250\end{array}$ & $\begin{array}{l}10 \\
30 \\
10 \\
60 \\
10\end{array}$ & $\begin{array}{l}13 \\
58 \\
20 \\
90 \\
30\end{array}$ & $\begin{array}{l}4 \\
-- \\
-\infty\end{array}$ & $\begin{array}{l}0.8 \\
0.5 \\
0.5 \\
0.7 \\
0.3\end{array}$ & $\begin{array}{r}17 \\
215 \\
221 \\
60 \\
180\end{array}$ & $\begin{array}{r}1-54 \\
12-57 \\
4-63 \\
2-54 \\
1-54\end{array}$ & $\begin{array}{l}-\infty \\
-\infty \\
-\infty\end{array}$ & $\begin{array}{l}- \\
- \\
-\infty\end{array}$ & $=-$ & $\begin{array}{l}= \\
= \\
=\end{array}$ \\
\hline $\begin{array}{l}21 \\
22 \\
23 \\
24 \\
25\end{array}$ & $\begin{array}{l}\text { ANTHONY VERANGE } \\
\text { HARMYK AND SONS } \\
\text { J DUNCAN } \\
\text { BELL TELE CO } \\
\text { BELL TELE CO }\end{array}$ & $\begin{array}{l}\text { VERANGE 1 } \\
\text { HARMYK 1 } \\
\text { BELL LAB } 3 \\
\text { BELL LAB } 2\end{array}$ & $\begin{array}{l}250 \\
205 \\
145 \\
120 \\
120\end{array}$ & $\begin{array}{r}30 \\
350 \\
20 \\
300 \\
300\end{array}$ & $\begin{array}{r}4 \\
56 \\
23 \\
-- \\
--\end{array}$ & $\begin{array}{r}4 \\
9 \\
-- \\
--\end{array}$ & $\begin{array}{l}7.5 \\
6.2 \\
0.9 \\
-.- \\
--\end{array}$ & $\begin{array}{r}174 \\
174 \\
75 \\
40 \\
51\end{array}$ & $\begin{array}{r}-54 \\
1-56 \\
8-54 \\
10-66 \\
10-60\end{array}$ & $=$ & $\begin{array}{l}- \\
= \\
11-70\end{array}$ & $=$ & $=$ \\
\hline $\begin{array}{l}26 \\
27 \\
28 \\
29 \\
30\end{array}$ & $\begin{array}{l}\text { BELL TELE CO } \\
\text { JOSEPH MORREL } \\
\text { ROY DENSON } \\
\text { MRS HAROING } \\
\text { NICK PETRUZELLA }\end{array}$ & $\begin{array}{l}\text { BELL LAB } 1 \\
\text { MORREL } \\
\text { DENSON } 1 \\
\text { HARDING } 1 \\
\end{array}$ & $\begin{array}{l}120 \\
76 \\
100 \\
120 \\
130\end{array}$ & $\begin{array}{l}300 \\
-- \\
15 \\
35 \\
25\end{array}$ & $\begin{array}{r}-- \\
-- \\
8 \\
62\end{array}$ & $=-$ & $\begin{array}{l}-- \\
3.0 \\
4.4 \\
0.4\end{array}$ & $\begin{array}{r}54 \\
5 \\
5 \\
50 \\
43\end{array}$ & $\begin{array}{r}12-66 \\
9-55 \\
10-64 \\
1-49 \\
10-49\end{array}$ & $\begin{array}{l}- \\
-- \\
-\infty\end{array}$ & $\begin{array}{l}- \\
-59 \\
-\infty \\
=-\end{array}$ & $\begin{array}{l}- \\
= \\
= \\
=\end{array}$ & $\begin{array}{l}= \\
= \\
= \\
=\end{array}$ \\
\hline $\begin{array}{l}31 \\
32 \\
33 \\
34 \\
35\end{array}$ & $\begin{array}{l}\text { RED BANK W D } \\
\text { NOVAK } \\
\text { RUMSON C CLUB } \\
\text { JOHN LEMLI I } \\
\text { MARLBORO S HOSP }\end{array}$ & $\begin{array}{l}\text { RBWD } 2 \\
\text { HULSART } \\
\text { RUMSON C C } 1 \\
\text { STATE HOSP } 6\end{array}$ & $\begin{array}{r}30 \\
110 \\
7 \\
160 \\
140\end{array}$ & $\begin{array}{l}525 \\
=- \\
10 \\
200\end{array}$ & $\begin{array}{l}53 \\
-- \\
- \\
20 \\
92\end{array}$ & $\begin{array}{l}= \\
= \\
=\end{array}$ & $\begin{array}{l}9.9 \\
-- \\
0.5 \\
2.2\end{array}$ & $\begin{array}{r}27 \\
16 \\
-- \\
70 \\
57\end{array}$ & $\begin{array}{c}4-56 \\
1-58 \\
-- \\
5-54 \\
10-69\end{array}$ & $\begin{array}{l}13 \\
34 \\
12 \\
- \\
-\end{array}$ & $\begin{array}{c}-59 \\
11-70 \\
11-70 \\
-- \\
--\end{array}$ & $\begin{array}{l}-\infty \\
=- \\
=-\end{array}$ & $\begin{array}{l}= \\
= \\
=\end{array}$ \\
\hline $\begin{array}{l}36 \\
37 \\
38 \\
39 \\
40\end{array}$ & $\begin{array}{l}\text { MARLBORO S HOSP } \\
\text { MARLBORO S HOSP } \\
\text { MRS A ONORATO } \\
\text { RED BANK WO } \\
\text { W SCHIEMEYER }\end{array}$ & 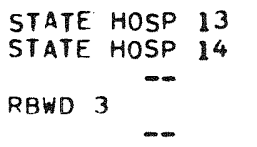 & $\begin{array}{r}140 \\
125 \\
120 \\
35 \\
80\end{array}$ & $\begin{array}{r}370 \\
300 \\
9 \\
421 \\
15\end{array}$ & $\begin{array}{l}54 \\
-- \\
38 \\
159 \\
--\end{array}$ & $=$ & $\begin{array}{l}6.9 \\
-.-2 \\
0.2 \\
2.6 \\
--\end{array}$ & $\begin{array}{c}62 \\
-- \\
35 \\
25 \\
18\end{array}$ & $\begin{array}{c}11-53 \\
-- \\
7-53 \\
6-46 \\
9-53\end{array}$ & $\begin{array}{l}59 \\
-\infty \\
39 \\
=-\end{array}$ & $\begin{array}{c}11-70 \\
=- \\
11-70 \\
=-\infty\end{array}$ & $\begin{array}{l}-\infty \\
= \\
-\infty\end{array}$ & $\begin{array}{l}= \\
=- \\
=\end{array}$ \\
\hline
\end{tabular}


Table 6.--Yield and water-level data for wells developed in the Englishtown aquifer in Monmouth and Ocean Counties--Continued

\begin{tabular}{|c|c|c|}
\hline $\begin{array}{l}\text { MAP } \\
\text { NO }\end{array}$ & OW VER & $\begin{array}{l}\text { LOCAL } \\
\text { WELLL } \\
\text { NUMBER }\end{array}$ \\
\hline $\begin{array}{l}41 \\
42 \\
43 \\
44 \\
45\end{array}$ & $\begin{array}{l}\text { MARLBORO S HOSP } \\
\text { MARLBORO S HOSP } \\
\text { MON BCH CLO STR } \\
\text { HSL FARMS } \\
\text { RE MORGAN }\end{array}$ & $\begin{array}{l}\text { STATE HOSP } 4 \\
\text { STATE HOSP } 5 \\
\text { MBCS } 2 \\
\\
-- \\
--\end{array}$ \\
\hline $\begin{array}{l}46 \\
47 \\
48 \\
49 \\
50\end{array}$ & $\begin{array}{l}\text { HENRY HIGGINS } \\
\text { M ROSENBERG } \\
\text { J P FOCARILE } \\
\text { VILLAGE WC } \\
\text { OLD ORCHARD C C }\end{array}$ & $\begin{array}{l}\text { ROSENBERG } 1 \\
\text { FOCARILE } \\
\text { VILLAGE } 215 \\
\text { OLD ORCHARD } 1\end{array}$ \\
\hline $\begin{array}{l}51 \\
52 \\
53 \\
54 \\
55\end{array}$ & $\begin{array}{l}\text { CEDAR DR EL SCH } \\
\text { GEORGE THOMPSON } \\
R \text { H MACY \& CO } \\
\text { E R DURAND } \\
\text { TAYLOR PALMER }\end{array}$ & BAMBERGER \\
\hline $\begin{array}{l}56 \\
57 \\
58 \\
59 \\
60\end{array}$ & $\begin{array}{l}\text { TENNENT ORCH I } \\
\text { SO GULF UTIL } \\
\text { ATLANTIC TWP SC } \\
\text { K A JADASSOHN } \\
\text { ROY H KIRSHNER }\end{array}$ & $\begin{array}{l}\text { SO GULF ì } \\
\text { ATLANTIC SCH } \\
-- \\
--\end{array}$ \\
\hline $\begin{array}{l}61 \\
62 \\
63 \\
64 \\
65\end{array}$ & $\begin{array}{l}\text { FREEHOLD TWP WD } \\
\text { ABE COHEN } \\
\text { FRANK GUMINA } \\
\text { MONMOUTH COUNTY } \\
\text { AM KARAGHEUSIAN }\end{array}$ & $\begin{array}{l}\text { POINT IVY } 1 \\
\text { GUMINA } 1 \\
\text { MO COC H } 2 \\
1\end{array}$ \\
\hline $\begin{array}{l}66 \\
67 \\
68 \\
69 \\
70\end{array}$ & $\begin{array}{l}\text { BOY SCOUTS AMER } \\
\text { MR SCATUORCHIO } \\
F \text { J MOREAU } \\
\text { GEORGE MOUNT } \\
\text { MANALAPAN C }\end{array}$ & $\begin{array}{l}\text { QUAIL HILL } 1 \\
\text { SCATUORCHIO } 1 \\
\text { MOUNT } 2-- \\
\text { MANALAPAN } 1\end{array}$ \\
\hline $\begin{array}{l}71 \\
72 \\
73 \\
74 \\
75\end{array}$ & $\begin{array}{l}S \text { WURTZEL } \\
\text { C BOROUNOVICH } \\
\text { BROCKWAY GLASS } \\
\text { SEASIDE INVEST } \\
\text { LFON VASSEUR }\end{array}$ & $\begin{array}{r}=- \\
B R O C K W A Y \\
=- \\
=-\end{array}$ \\
\hline $\begin{array}{l}76 \\
77 \\
78 \\
79 \\
80\end{array}$ & $\begin{array}{l}\text { ARE KUHL } \\
\text { CLAYTON WM D } \\
\text { D MAYK } \\
\text { HENRY IKOFF } \\
\text { FREEHOLD TWP }\end{array}$ & CLAYTON $\overline{2}^{--}$ \\
\hline
\end{tabular}

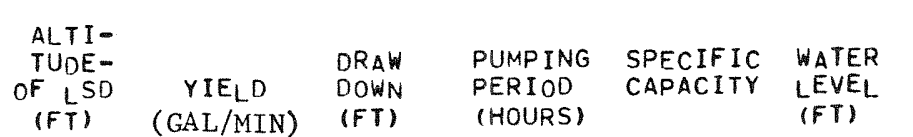

125
135
10
160
140
170
80
95
120
40

\section{0}

100
100
480
55
20
12

$\begin{array}{rrr}-- & -- & -- \\ -- & -- & -\overline{1} \\ 136 & 8 & 3.5 \\ 85 & 6 & 0.6 \\ 70 & 6 & 0.3 \\ 27 & -- & 0.4 \\ 40 & 8 & 2.5 \\ 30 & -- & 0.3 \\ 110 & 48 & 2.7 \\ 180 & 10 & 1.1\end{array}$

122
100

122
100
70

180
90

130
200
86

86
120
95

130
84

130
84
190
170
150

250

250
140
185

185
135
122

122

180
160
130

130
160

160
140

230
180
145

145

12
100
10
292

200

75

123

15
15

100
8
63
30
13

8
-24

24

12
80
25
10

25
10
10

1486

1486
12
200
275
240

240

65

30

12

240

10
10
220
20

20
10

10
530
12

FREEHOLO TWP WD KOENIG LANE 2
140
30

30
30
27

159

$-30$

30
140
88

-25
154

$154 \quad 6$

7
40
56
62
3

--
-
$-\infty$

34
154
35
15
160
60
DATE

WATER MEASURED

WATER
LEVEL

DATE

WATER WATER WATE

LEVEL LEVEL LEVEL

MEASURED (FT)

MEASUREO

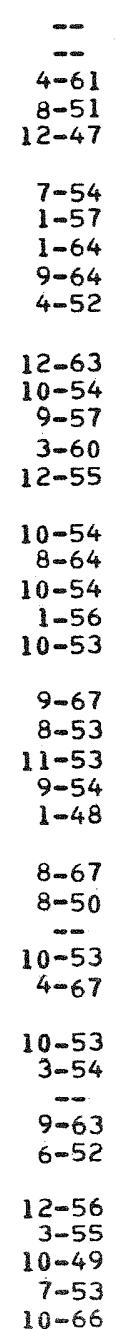$$
\text { . }
$$$$
=\overline{-}=
$$$$
\begin{aligned}
& = \\
& = \\
& =
\end{aligned}
$$$$
=\quad=
$$

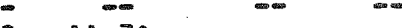

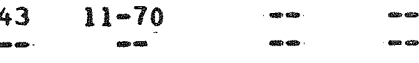$$
=\quad=\quad=-
$$

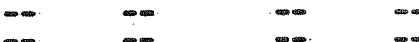$$
=\quad=\quad=\quad=
$$

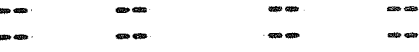

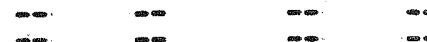$$
109 \quad=
$$$$
0.8
$$$$
0.3
$$$$
9.3
$$$$
6.7
$$$$
\begin{aligned}
& 2.0 \\
& 2.7
\end{aligned}
$$$$
-\infty .5
$$$$
0.5
$$$$
1.4
$$$$
\begin{array}{r}
0.2 \\
3.9
\end{array}
$$$$
0.3
$$$$
0.3
$$$$
0.3
$$$$
0.9
$$

$10-66$

$17 \quad 11-70 \quad-\infty \quad-$

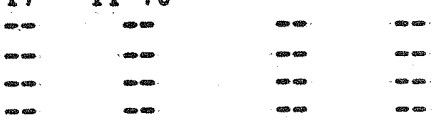

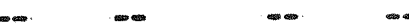

$72 \quad \begin{gathered}1059 \\ 72=-\end{gathered}$

$\begin{array}{lll}4 & 11-70 \quad & -5\end{array}$

$\begin{array}{cccc}\square & = & = & = \\ 47 & 11-70 & = \\ \because- & =- & = \\ 9 & 12-58 & = & =\end{array}$

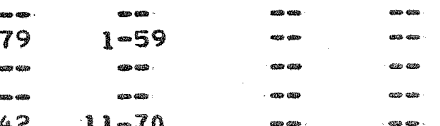




\begin{tabular}{|c|c|c|c|c|c|c|c|c|c|c|c|c|c|}
\hline $\begin{array}{r}\text { MAP } \\
\text { NO }\end{array}$ & OWNER & $\begin{array}{l}\text { LOCAL } \\
\text { WELL } \\
\text { NUMBER }\end{array}$ & $\begin{array}{l}\text { ALTI- } \\
\text { TUDE- } \\
\text { OF LSD } \\
\text { (FT) }\end{array}$ & $\begin{array}{c}\text { YIELD } \\
\text { (GAL/MIN) }\end{array}$ & $\begin{array}{l}\text { DRAW } \\
\text { DOWN } \\
\text { (FT) }\end{array}$ & $\begin{array}{l}\text { PUMPING } \\
\text { PERIOD } \\
\text { (HOURS) }\end{array}$ & $\begin{array}{l}\text { SPECIFIC } \\
\text { CAPACITY }\end{array}$ & $\begin{array}{l}\text { WATER } \\
\text { LEVEL } \\
(F T)\end{array}$ & $\begin{array}{l}\text { DATE } \\
\text { WATER } \\
\text { LEVEL } \\
\text { MEASURED }\end{array}$ & $\begin{array}{l}\text { WATER } \\
\text { LEVEL } \\
\text { (FT) }\end{array}$ & $\begin{array}{l}\text { DATE } \\
\text { WATER } \\
\text { LEVEL } \\
\text { MEASURED }\end{array}$ & $\begin{array}{l}\text { WATER } \\
\text { LEVEL } \\
\text { (FT) }\end{array}$ & $\begin{array}{l}\text { DATE } \\
\text { WATER } \\
\text { LEVEL } \\
\text { MEASURED }\end{array}$ \\
\hline $\begin{array}{l}81 \\
82 \\
83 \\
84 \\
85\end{array}$ & $\begin{array}{l}\text { ALLENHURST W } \text { W } \\
\text { ALLENHURST W } \\
\text { ASBURY PARK W } \\
\text { MONMOUTH CON WC } \\
\text { MONMOUTH CON WC }\end{array}$ & $\begin{array}{l}\text { AWD } 2 \\
\text { AWD } 4 \\
\text { APWD } 4 \\
\text { WHITESVILLE } 3 \\
\text { OCEAN GROVE } 20\end{array}$ & $\begin{array}{l}10 \\
10 \\
10 \\
10 \\
20\end{array}$ & $\begin{array}{l}525 \\
524 \\
500 \\
465 \\
300\end{array}$ & $\begin{array}{l}169 \\
123 \\
160 \\
162 \\
134\end{array}$ & $\begin{array}{r}-8 \\
8 \\
4 \\
-\end{array}$ & $\begin{array}{l}3.1 \\
4.3 \\
3.1 \\
2.9 \\
2.2\end{array}$ & $\begin{array}{r}45 \\
90 \\
- \\
50 \\
61\end{array}$ & $\begin{array}{l}7-50 \\
7-50 \\
5-63 \\
3-54 \\
6-49\end{array}$ & $\begin{array}{r}-54 \\
-58 \\
108\end{array}$ & $\begin{array}{c}-\infty \\
1-59 \\
11-70 \\
11-70\end{array}$ & $\begin{array}{l}-- \\
84 \\
-- \\
-\infty\end{array}$ & $\begin{array}{c}11-70 \\
-\infty \\
-\infty\end{array}$ \\
\hline $\begin{array}{l}86 \\
87 \\
88 \\
89 \\
90\end{array}$ & $\begin{array}{l}\text { FARMINGDALE }: \text { D } \\
\text { FARMINGDALE } \\
\text { FARMINGDALE } \\
\text { FARMINGDALE } \\
\text { MRS ERRICKSON }\end{array}$ & $\begin{array}{cc}\text { FARMINGDALE } & 1 \\
\text { FARMINGDALE } & 2 \\
\text { FARMINGDALE } & 4 \\
\text { FARMINGDALE } & 3 \\
-- & \end{array}$ & $\begin{array}{r}80 \\
80 \\
85 \\
80 \\
130\end{array}$ & $\begin{array}{r}300 \\
90 \\
302 \\
300 \\
5\end{array}$ & $\begin{array}{l}15 \\
155 \\
118 \\
146 \\
93\end{array}$ & $\begin{array}{r}-- \\
8 \\
8 \\
--\end{array}$ & $\begin{array}{l}-\infty \\
0.6 \\
2.6 \\
2.1 \\
0.1\end{array}$ & $\begin{array}{r}- \\
45 \\
130 \\
86 \\
37\end{array}$ & $\begin{array}{r}-- \\
1=49 \\
12-70 \\
8-64 \\
9-54\end{array}$ & $\begin{array}{l}71 \\
-\infty \\
-\infty\end{array}$ & $\begin{array}{l}1=59 \\
=- \\
=- \\
=-\end{array}$ & $\begin{array}{l}= \\
= \\
= \\
=\end{array}$ & $\begin{array}{l}= \\
= \\
= \\
=\end{array}$ \\
\hline $\begin{array}{l}91 \\
92 \\
93 \\
94 \\
95\end{array}$ & $\begin{array}{l}\text { MR VANHISE } \\
\text { BELMAR BORO WD } \\
\text { DEPT OF ARMY } \\
\text { DUNCAN THECKER } \\
\text { BELMAR BORO WD }\end{array}$ & $\begin{array}{l}\text { BWD } 4 \text { ELEC } \\
\text { IMPERIAL PARK2 } \\
\text { D T ASSOC } 1 \\
\text { BWD } 8 \text { SUB }\end{array}$ & $\begin{array}{r}145 \\
15 \\
100 \\
100 \\
20\end{array}$ & $\begin{array}{r}10 \\
630 \\
302 \\
80 \\
--\end{array}$ & $\begin{array}{r}85 \\
103 \\
73 \\
48 \\
--\end{array}$ & $\begin{array}{l}=- \\
=- \\
=-\end{array}$ & $\begin{array}{l}0.1 \\
6.1 \\
4.1 \\
1.7 \\
-.\end{array}$ & $\begin{array}{r}35 \\
62 \\
87 \\
-7\end{array}$ & $\begin{array}{c}7-54 \\
7-41 \\
4-43 \\
6-69 \\
-\infty\end{array}$ & $\begin{array}{r}-\infty \\
151 \\
206 \\
7 \\
--\end{array}$ & $\begin{array}{l}-> \\
11-70 \\
11-70 \\
11-70 \\
-\infty\end{array}$ & $=-$ & $\begin{array}{l}-\infty \\
=- \\
=- \\
=-\end{array}$ \\
\hline $\begin{array}{r}96 \\
97 \\
98 \\
99 \\
100\end{array}$ & 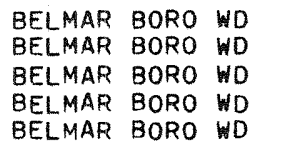 & $\begin{array}{lll}\text { BWD } & 5 & \text { SUB } \\
\text { BWD } & 1 & \text { ELEC } \\
\text { BWD } & 3 & \text { SUB } \\
\text { BWD } & 6 & \text { SUB } \\
\text { BWD } & 1 & \text { SUB }\end{array}$ & $\begin{array}{l}20 \\
20 \\
20 \\
20 \\
20\end{array}$ & $=$ & $\begin{array}{l}=- \\
=- \\
=\end{array}$ & $\begin{array}{l}= \\
=- \\
=-\end{array}$ & $\begin{array}{l}= \\
-- \\
--\end{array}$ & $\begin{array}{l}= \\
=- \\
=\end{array}$ & $\begin{array}{l}m \\
m- \\
m\end{array}$ & $\begin{array}{l}173 \\
-\infty \\
-\infty\end{array}$ & $\begin{array}{c}-\infty \\
11-70 \\
-\infty \\
-\infty \\
=-\end{array}$ & $\begin{array}{l}-\infty \\
-\infty \\
-\infty\end{array}$ & $\begin{array}{l}= \\
=- \\
=- \\
=-\end{array}$ \\
\hline $\begin{array}{l}101 \\
102 \\
103 \\
104 \\
105\end{array}$ & $\begin{array}{l}\text { BELMAR BORO WD } \\
\text { BELMAR BORO WD } \\
\text { BELMAR BORO WD } \\
\text { BELMAR BORO WD } \\
\text { WALL TWP WD }\end{array}$ & $\begin{array}{l}\text { BWD } 4 \text { SUB } \\
\text { BWD } 2 \text { ELEC } \\
\text { BWD } 3 \text { ELEC } \\
\text { BWD } 7 \text { SUB } \\
\text { WEST BELMAR }\end{array}$ & $\begin{array}{l}20 \\
20 \\
20 \\
20 \\
25\end{array}$ & $\begin{array}{l}-\infty \\
305 \\
400\end{array}$ & $\begin{array}{l}-- \\
162 \\
225\end{array}$ & $=$ & $\begin{array}{l}-- \\
1.9 \\
1.8\end{array}$ & $\begin{array}{l}-\overline{20} \\
100 \\
-112\end{array}$ & $\begin{array}{c}-- \\
-- \\
10-49 \\
-\infty \\
9-59\end{array}$ & $\begin{array}{l}-\infty \\
= \\
=\end{array}$ & $\begin{array}{l}= \\
= \\
=\end{array}$ & $=$ & $\begin{array}{l}= \\
= \\
=\end{array}$ \\
\hline $\begin{array}{l}106 \\
107 \\
108 \\
109 \\
110\end{array}$ & $\begin{array}{l}\text { WALL TWP D } \\
C \text { I SMITH } \\
U \text { FREEHOLD B ED } \\
\text { SPRING LAKE } \\
\text { SPRING LAKE D D }\end{array}$ & $\begin{array}{l}\text { RT } 34 \text { WELL } \\
\text { BOARD ED } 1 \\
\text { SLWD } 4 \\
\text { SLWD } 3\end{array}$ & $\begin{array}{r}80 \\
130 \\
135 \\
10 \\
20\end{array}$ & $\begin{array}{r}402 \\
20 \\
15 \\
608 \\
545\end{array}$ & $\begin{array}{r}116 \\
57 \\
121 \\
115 \\
128\end{array}$ & $\begin{array}{r}8 \\
-6 \\
-\infty\end{array}$ & $\begin{array}{l}3.5 \\
0.4 \\
0.1 \\
5.3 \\
4.3\end{array}$ & $\begin{array}{r}206 \\
25 \\
24 \\
145 \\
62\end{array}$ & $\begin{array}{l}1-68 \\
8-53 \\
2-51 \\
8-65 \\
6-41\end{array}$ & $\begin{array}{r}242 \\
-\infty \\
172 \\
120\end{array}$ & $\begin{array}{c}11-70 \\
=- \\
=-70 \\
11-70 \\
12-58\end{array}$ & $\begin{array}{l}-\infty \\
-\infty \\
-\infty\end{array}$ & $\begin{array}{l}= \\
=- \\
= \\
=\end{array}$ \\
\hline $\begin{array}{l}111 \\
112 \\
113 \\
114 \\
115\end{array}$ & $\begin{array}{l}\text { ALDRICH W CO } \\
\text { US GEOL SURVEY } \\
\text { SPRING LK HT WD } \\
\text { SPRING LK HT WD } \\
\text { SPRING LAKE W D }\end{array}$ & $\begin{array}{l}\text { ALORICH W } \text { CO } 4 \\
\text { ALLAIRE S } P \text { P } \\
\text { SPRING LK HGTZ } \\
\text { SPRING LK HGT3 } \\
\text { SLWD I }\end{array}$ & $\begin{array}{r}130 \\
96 \\
60 \\
25 \\
15\end{array}$ & $\begin{array}{l}1100 \\
510 \\
457 \\
600\end{array}$ & $\begin{array}{r}149 \\
118 \\
115 \\
57\end{array}$ & $\begin{array}{r}8 \\
-8 \\
8 \\
-8\end{array}$ & $\begin{array}{l}7.4 \\
-\infty .3 \\
4.0 \\
10.5\end{array}$ & $\begin{array}{r}165 \\
100 \\
125 \\
180 \\
97\end{array}$ & $\begin{array}{r}8-67 \\
12-63 \\
5-53 \\
11-66 \\
8-40\end{array}$ & $\begin{array}{r}185 \\
205 \\
-206 \\
145\end{array}$ & $\begin{array}{l}11-70 \\
11-70 \\
=- \\
11-70 \\
12-58\end{array}$ & $\begin{array}{l}= \\
= \\
196\end{array}$ & $\begin{array}{c}= \\
= \\
11=70\end{array}$ \\
\hline $\begin{array}{l}116 \\
117 \\
118 \\
119 \\
120\end{array}$ & $\begin{array}{l}\text { SPRING LAKE W D } \\
\text { E HARVEY } \\
\text { JACKSON TWP MUA } \\
\text { WALL TWP WD } \\
\text { WALL TWP W D }\end{array}$ & $\begin{array}{l}\text { SLWD } 2 \\
\text { JACKSON } 2 \\
\text { ALLENWOOD } 1 \\
\text { ALLENWOOD } 2\end{array}$ & $\begin{array}{r}15 \\
115 \\
156 \\
100 \\
80\end{array}$ & $\begin{array}{l}535 \\
100 \\
412 \\
400 \\
400\end{array}$ & $\begin{array}{r}103 \\
10 \\
109 \\
100 \\
98\end{array}$ & $\begin{array}{l}11 \\
-8 \\
10 \\
10\end{array}$ & $\begin{array}{r}5.2 \\
10.0 \\
3.8 \\
4.0 \\
4.1\end{array}$ & $\begin{array}{l}91 \\
10 \\
144 \\
185 \\
167\end{array}$ & $\begin{array}{r}7-41 \\
8-50 \\
11-62 \\
10-59 \\
11-59\end{array}$ & $\begin{array}{r}-\infty \\
231 \\
256\end{array}$ & $\begin{array}{l}-\infty \\
11-70 \\
11-70\end{array}$ & $-\infty$ & $\begin{array}{l}- \\
=- \\
= \\
=\end{array}$ \\
\hline
\end{tabular}


Table 6.--Yield and water-level data for wells developed in the Englishtown aquifer in Monmouth and Ocean Counties--Continued

\begin{tabular}{|c|c|c|c|c|c|c|c|c|c|c|c|c|c|}
\hline $\begin{array}{l}\text { MAP } \\
\text { NO }\end{array}$ & OWNER & $\begin{array}{l}\text { LOCAL } \\
\text { WELLL } \\
\text { NUMBER }\end{array}$ & $\begin{array}{l}\text { ALTI- } \\
\text { TUDE- } \\
O F \quad L S D \\
(F T)\end{array}$ & $\begin{array}{c}Y I E_{L} D \\
(\text { GAL/MIN) }\end{array}$ & $\begin{array}{l}\text { DRAW } \\
\text { DOWN } \\
(F T)\end{array}$ & $\begin{array}{l}\text { PUMP ING } \\
\text { PERI OD } \\
\text { (HOURS) }\end{array}$ & $\begin{array}{l}\text { SPECIFIC } \\
\text { CAPACITY }\end{array}$ & $\begin{array}{l}\text { WATER } \\
\text { LEVEL } \\
(F T)\end{array}$ & $\begin{array}{l}\text { DATE } \\
\text { WATER } \\
\text { LEVEL } \\
\text { MEASURED }\end{array}$ & $\begin{array}{l}\text { WATER } \\
\text { LEVEL } \\
\text { (FT) }\end{array}$ & $\begin{array}{l}\text { DATE } \\
\text { WATER } \\
\text { LEVEL } \\
\text { MEASURED }\end{array}$ & $\begin{array}{l}\text { WATER } \\
\text { LEVEL } \\
\text { (FT) }\end{array}$ & $\begin{array}{l}\text { DATE } \\
\text { WATER } \\
\text { LEVEL } \\
\text { MEASURE }\end{array}$ \\
\hline $\begin{array}{l}121 \\
122 \\
123 \\
124 \\
125\end{array}$ & $\begin{array}{l}\text { SEA GIRT W D } \\
\text { SEA GIRT W D } \\
\text { ATLEE ZURLO } \\
\text { JACKSON TWP MUA } \\
\text { HOWELL TWP BD }\end{array}$ & $\begin{array}{l}\text { SGWD } 5 \\
\text { SGWD } 4 \\
\text { JACKSON } 4 \\
\text { KENT RD }\end{array}$ & $\begin{array}{r}20 \\
18 \\
90 \\
80 \\
110\end{array}$ & $\begin{array}{r}400 \\
310 \\
20 \\
520 \\
120\end{array}$ & $\begin{array}{l}62 \\
157 \\
-2 \\
150 \\
49\end{array}$ & $\begin{array}{r}8 \\
24 \\
4 \\
8 \\
8\end{array}$ & $\begin{array}{l}6.5 \\
2.0 \\
--\infty \\
3.5 \\
2.4\end{array}$ & $\begin{array}{r}178 \\
103 \\
30 \\
90 \\
96\end{array}$ & $\begin{array}{r}11-63 \\
7-49 \\
9-52 \\
7-65 \\
2-55\end{array}$ & $\begin{array}{r}188 \\
-\infty \\
133\end{array}$ & $\begin{array}{c}11-70 \\
-\infty \\
=- \\
11-70 \\
=-\end{array}$ & $\begin{array}{l}-\infty \\
= \\
-\infty\end{array}$ & $=$ \\
\hline $\begin{array}{l}126 \\
127 \\
128 \\
129 \\
130\end{array}$ & $\begin{array}{l}\text { SEA GIRT W D } \\
\text { JACKSON TWP MUA } \\
\text { JACKSON TWP MUA } \\
\text { BRIELLE WATER D } \\
\text { ST GABRIELS COL }\end{array}$ & $\begin{array}{l}\text { SGWD } 3 \\
\text { JACKSON } 3 \\
\text { JACKSON } 1 \\
\text { BWD 2 } \\
\text { ST GABRIELS } 1\end{array}$ & $\begin{array}{r}20 \\
140 \\
110 \\
33 \\
70\end{array}$ & $\begin{array}{l}300 \\
421 \\
415 \\
510 \\
130\end{array}$ & $\begin{array}{r}54 \\
76 \\
111 \\
110 \\
166\end{array}$ & $\begin{array}{r}-- \\
8 \\
-- \\
--\end{array}$ & $\begin{array}{l}5.6 \\
5.5 \\
3.7 \\
4.6 \\
0.8\end{array}$ & $\begin{array}{r}47 \\
119 \\
101 \\
75 \\
34\end{array}$ & $\begin{array}{l}--5 \\
5-62 \\
7-61 \\
2-50 \\
-57\end{array}$ & $\begin{array}{l}-\infty \\
193 \\
201 \\
110 \\
149\end{array}$ & $\begin{array}{l}-\infty \\
11-70 \\
11-70 \\
12-58 \\
11-70\end{array}$ & $=$ & $\begin{array}{c}-\infty \\
-\infty \\
11=70 \\
-\infty\end{array}$ \\
\hline $\begin{array}{l}131 \\
132 \\
133 \\
134 \\
135\end{array}$ & $\begin{array}{l}\text { PARKWAY WC } \\
\text { BRIELLE WATER D } \\
\text { LAKEWOOD WC } \\
\text { LAKEWOOD WCC } \\
\text { LAKESORE LAUNDR }\end{array}$ & $\begin{array}{l}\text { PARKWAY 1 } \\
\text { BWD } 3 \\
\text { LAKEWOOD } 9 \\
\text { LAKEWOOD } 6 \\
\text { LAKESHORE LA } 1\end{array}$ & $\begin{array}{l}45 \\
90 \\
55 \\
70 \\
50\end{array}$ & $\begin{array}{r}179 \\
400 \\
412 \\
503 \\
70\end{array}$ & $\begin{array}{r}85 \\
95 \\
147 \\
109 \\
135\end{array}$ & $\begin{array}{r}5 \\
-- \\
24 \\
8 \\
--\end{array}$ & $\begin{array}{l}2.1 \\
4.2 \\
2.8 \\
4.6 \\
0.5\end{array}$ & $\begin{array}{r}81 \\
225 \\
126 \\
93 \\
50\end{array}$ & $\begin{array}{c}8-58 \\
-\infty \\
5-68 \\
11-60 \\
-\infty\end{array}$ & $\begin{array}{l}268 \\
170 \\
180 \\
-\infty\end{array}$ & $\begin{array}{c}-\infty \\
11=70 \\
11-70 \\
11-70 \\
=\infty\end{array}$ & $=$ & $=$ \\
\hline $\begin{array}{l}136 \\
137 \\
138 \\
139 \\
140\end{array}$ & $\begin{array}{l}\text { LAKEWOOD W } \\
\text { LAKEWOOD } \\
\text { LAKEWOOD } \\
\text { LAKE } \\
\text { LAKEWOOD W } \\
\text { LAKEWOOD }\end{array}$ & $\begin{array}{l}\text { LAKEWOOD W C } \\
\text { LAKEWOOD } 2 \\
\text { LAKEWOOD W } \\
\text { LAKEWOOD } 5 \\
\text { LAKEWOOD }\end{array}$ & $\begin{array}{l}35 \\
60 \\
30 \\
40 \\
30\end{array}$ & $\begin{array}{l}-3 \\
300 \\
-\infty 15 \\
-\infty\end{array}$ & $\begin{array}{l}- \\
- \\
91 \\
--\end{array}$ & $\begin{array}{l}-\infty \\
-- \\
-\infty \\
-\infty\end{array}$ & $\begin{array}{l}-\infty \\
-\infty \\
2.4\end{array}$ & $\begin{array}{r}-m \\
20 \\
+20 \\
67 \\
46\end{array}$ & $\begin{array}{c}-\infty \\
-\infty \\
5-57 \\
-\infty\end{array}$ & $\begin{array}{l}= \\
= \\
= \\
124\end{array}$ & $\begin{array}{c}= \\
=- \\
=-70\end{array}$ & $\begin{array}{l}-\infty \\
-\infty \\
-\infty \\
-\infty\end{array}$ & $=$ \\
\hline $\begin{array}{l}141 \\
142 \\
143 \\
144 \\
145\end{array}$ & $\begin{array}{l}\text { PT PLEASANT } \\
\text { PT PLEASANT } \\
\text { PT } \\
\text { PT PLEASANT } \\
\text { PT PLEASANT } \\
\text { PT } \\
\text { PT PLEASANT }\end{array}$ & $\begin{array}{ll}\text { PPWD } & 3 \\
\text { PPWD } & 6 \\
\text { PPWD } & 2 \\
\text { PPWD } & 1 \\
\text { PPWD }\end{array}$ & $\begin{array}{l}15 \\
20 \\
15 \\
20 \\
10\end{array}$ & $\begin{array}{l}300 \\
517 \\
265 \\
277 \\
-\infty\end{array}$ & $\begin{array}{r}117 \\
225 \\
83 \\
57 \\
--\end{array}$ & $\begin{array}{r}48 \\
8 \\
21 \\
4 \\
--\end{array}$ & $\begin{array}{l}2.6 \\
2.3 \\
3.2 \\
4.9 \\
--\end{array}$ & $\begin{array}{r}56 \\
146 \\
34 \\
30 \\
+35\end{array}$ & $\begin{array}{l}4-46 \\
5-65 \\
9-36 \\
6-36 \\
--\end{array}$ & $\begin{array}{l}224 \\
-\infty \\
-\infty\end{array}$ & $\begin{array}{c}11-70 \\
=- \\
= \\
=-\end{array}$ & $\begin{array}{l}= \\
=- \\
=\end{array}$ & $=$ \\
\hline $\begin{array}{l}146 \\
147 \\
148 \\
149 \\
150\end{array}$ & $\begin{array}{l}\text { LAKEWOOD W C } \\
\text { CENTRAL RR NJ } \\
\text { US GEOL SURVEY } \\
\text { LAKEWOOD W C } \\
\text { NEW EGYPT WC }\end{array}$ & $\begin{array}{l}\text { LAKEWOOD } 8 \\
\text { CENTRAL RR NJ } \\
\text { COLL MILLS TW } 1 \\
\text { LAKEWOOD } 7 \\
1\end{array}$ & $\begin{array}{r}78 \\
9 \\
137 \\
85 \\
75\end{array}$ & $\begin{array}{l}500 \\
250 \\
-\infty \\
350 \\
70\end{array}$ & $\begin{array}{r}230 \\
65 \\
-115 \\
=-\end{array}$ & $\begin{array}{r}8 \\
-- \\
-\infty\end{array}$ & $\begin{array}{l}2.2 \\
3.8 \\
--\infty \\
3.0 \\
-\infty\end{array}$ & $\begin{array}{r}84 \\
20 \\
56 \\
176 \\
+15\end{array}$ & $\begin{array}{c}12-65 \\
-0 \\
1-64 \\
5-64 \\
1-59\end{array}$ & $\begin{array}{r}194 \\
-\infty \\
57 \\
-\infty \\
-\infty\end{array}$ & $\begin{array}{c}11-70 \\
11-70 \\
-\infty \\
-\infty\end{array}$ & $=$ & $\begin{array}{l}-\infty \\
-\infty \\
-\infty\end{array}$ \\
\hline $\begin{array}{l}151 \\
152 \\
153 \\
154 \\
155\end{array}$ & $\begin{array}{l}\text { OCEAN CO } \\
\text { OCEAN CO } \\
\text { OCE } \\
\text { BRADLEES CORP } \\
\text { S LAKE WOOD } \\
\text { S LAKE }\end{array}$ & $\begin{array}{l}\text { BAY HEAD } 6 \\
\text { BAY HEAD } 5 \\
\text { BRADLEES WELLL } \\
\text { S LAKEWOOD } 3 \\
5 \text { LAKEWOOD } 2\end{array}$ & $\begin{array}{l}10 \\
10 \\
10 \\
45 \\
40\end{array}$ & $\begin{array}{l}338 \\
220 \\
300 \\
508 \\
400\end{array}$ & $\begin{array}{l}139 \\
75 \\
177 \\
176 \\
--\end{array}$ & $\begin{array}{r}24 \\
1 \\
12 \\
8 \\
-\infty\end{array}$ & $\begin{array}{l}2.4 \\
2.9 \\
1.7 \\
2.9 \\
-\infty\end{array}$ & $\begin{array}{r}104 \\
64 \\
138 \\
143 \\
-\infty\end{array}$ & $\begin{array}{c}9-50 \\
3-47 \\
9-69 \\
8-66 \\
--\end{array}$ & $\begin{array}{r}202 \\
-\infty \\
204\end{array}$ & $\begin{array}{c}-\infty \\
11-70 \\
=-\infty \\
=-\infty \\
11=0\end{array}$ & $\begin{array}{l}- \\
=- \\
= \\
-\infty\end{array}$ & $\begin{array}{l}- \\
- \\
-\infty \\
-\infty\end{array}$ \\
\hline $\begin{array}{l}156 \\
157 \\
158 \\
159 \\
160 \\
161\end{array}$ & $\begin{array}{l}\text { S LAKEWOOD W } \\
\text { OCEAN CO } \\
\text { OCEAN CO } \\
\text { OCE } \\
\text { LAVALLETTE W D } \\
\text { LAVALLETTE W D } \\
\text { US GEOL SURVEY }\end{array}$ & $\begin{array}{l}\text { S LAKEWOOD } 1 \\
\text { MANTOLOKING } 4 \\
\text { MANTOLOKING } 6 \\
\text { LWD } 2 \\
\text { LWD } 3 \\
\text { TOMS RIVER TW2 }\end{array}$ & $\begin{array}{r}90 \\
5 \\
5 \\
5 \\
7 \\
15\end{array}$ & $\begin{array}{l}500 \\
-239 \\
512 \\
500 \\
--\end{array}$ & $\begin{array}{l}-\infty \\
224 \\
50 \\
240 \\
-\infty\end{array}$ & $\begin{array}{r}-\infty \\
-\infty \\
4 \\
4 \\
--\end{array}$ & $\begin{array}{c}-- \\
-- \\
1.1 \\
10.2 \\
2.1 \\
\ldots-\end{array}$ & $\begin{array}{l}-\infty \\
42 \\
58 \\
20 \\
58 \\
54\end{array}$ & $\begin{array}{c}-\infty \\
- \\
- \\
4-31 \\
7-48 \\
12-65\end{array}$ & $\begin{array}{r}245 \\
149 \\
-\infty \\
--\end{array}$ & $\begin{array}{c}11=70 \\
11=70 \\
=- \\
=-\end{array}$ & $=$ & $\begin{array}{l}- \\
-\infty \\
-\infty \\
-\infty \\
-\infty \\
--\end{array}$ \\
\hline
\end{tabular}



DATE TUDE DRILLED OF LSD
WELL DEPTH
LENGTH

CASING

CASING OIAM- OPEN TO

$\begin{array}{lll}\text { DEPTH } & \text { ETER } & \text { AQUIFER } \\ (F T) & \text { (IN) } & \text { (FEET) }\end{array}$

\begin{tabular}{|c|c|c|}
\hline $\begin{array}{l}402454 N 0741130.1 \\
402525 N 0740802.1 \\
402441 N 0740234.1 \\
402446 N 0740909.1 \\
402441 N 0740846.1\end{array}$ & $\begin{array}{l}\text { L BAHRENBURG } \\
\text { EDWARD LESKE } \\
\text { ATLAN HIGH W } \\
\text { A W ZELINSKI } \\
\text { LILY TULIP CUP }\end{array}$ & $\begin{array}{l}\text { BAHRENBURG } \\
\text { LESKE } 3 \\
\text { AHWD } 2 \\
1 \\
\text { LILY STAND }\end{array}$ \\
\hline $\begin{array}{l}402441 \text { N0740843.1 } \\
402438 N_{0} 740842.1 \\
402239 N_{0} 741434.1 \\
402232 N 0741441.1 \\
402238 \text { N0741410.1 }\end{array}$ & $\begin{array}{l}\text { LILY TULIP CUP } \\
\text { LILY TULIP CUP } \\
\text { LAVOIE LAB } \\
B \text { EDUC MARLBORO } \\
\text { B EDUC MARLBORO }\end{array}$ & $\begin{array}{l}\text { LILY TULIP } \\
\text { LILY TULIP } \\
\text { LAVOIE LAB } \\
\text { BOARD OF ED } \\
\text { BOARD OF ED }\end{array}$ \\
\hline $\begin{array}{l}402405 N_{0} 741145.1 \\
402354 N 0740134.1 \\
402323 N 0740307.1 \\
402325 N_{0} 741040.1 \\
402238 N 0741506.1\end{array}$ & $\begin{array}{l}\text { DONALD AHLERS } \\
\text { LF GRANOINETTI } \\
\text { JOSEPH STAVELA } \\
\text { GARDEN ST PKWY } \\
\text { RICHARD CARROLL }\end{array}$ & TELEGRAPH \\
\hline $\begin{array}{l}402238 N 0741539.1 \\
402235 N 0741125.1 \\
402311 N 0741249.1 \\
402223 N 0741024.1 \\
402210 N 0741127.1\end{array}$ & $\begin{array}{l}\text { JOHN GARRISON } \\
\text { US ARMY } \\
\text { NEIL BRY } \\
F \text { \& F NURSERIES } \\
G \text { HUBENY }\end{array}$ & $\begin{array}{l}\text { NIKE BASE } \\
\text { FF NURSERIE }\end{array}$ \\
\hline $\begin{array}{l}402210 N 0741127.2 \\
402222 N 0740832.1 \\
402208 N 0741059.1 \\
402256 N 0740950.1 \\
402208 N 0740952.1\end{array}$ & $\begin{array}{l}\text { ANTHONY VERANGE } \\
\text { HARMYK AND SONS } \\
\text { W J DUNCAN } \\
\text { BELL TELE CO } \\
\text { BELL TELE CO }\end{array}$ & $\begin{array}{l}\text { VERANGE } 1 \\
\text { HARMYK } 1 \\
\text { BELL LAB } \\
\text { BELL LAB } 2\end{array}$ \\
\hline $\begin{array}{l}402157 N_{0} 741003.1 \\
402143 N 0741852.1 \\
402138 N 0741532.1 \\
402121 N 0740942.1 \\
402120 N 0740919.1\end{array}$ & $\begin{array}{l}\text { BELL TELE CO } \\
\text { JOSEPH MORREL } \\
\text { ROY DENSON } \\
\text { MRS HARDING } \\
\text { NICK PETRUZELLA }\end{array}$ & $\begin{array}{l}\text { BELL LAB } 1 \\
\text { MORREL } \\
\text { DENSON } 1 \\
\text { HARDING } 1\end{array}$ \\
\hline $\begin{array}{l}402114 N 0740315.1 \\
402122 N 0741846.1 \\
402046 N 0740105.1 \\
402035 N 0741615.1 \\
402103 N 0741357.1\end{array}$ & $\begin{array}{l}\text { RED BANK W D } \\
\text { NOVAK } \\
\text { RUMSON C CLUB } \\
\text { JOHN LEMLI } \\
\text { MARLBORO S HOSP }\end{array}$ & $\begin{array}{l}\text { RBWD } 2 \\
\text { HULSART } \\
\text { RUMSON C C } \\
\text { STATE HOSP }\end{array}$ \\
\hline $\begin{array}{l}402103 N 0741351.1 \\
402109 N 0741346.1 \\
402020 N 0741804.1 \\
402020 N 0740411.1 \\
401921 N 0742100.1\end{array}$ & $\begin{array}{l}\text { MARLBORO S HOSP } \\
\text { MARLBORO S HOSP } \\
\text { MRS A ONORATO } \\
\text { RED BANK W D } \\
\text { W'SCHIEMEYER }\end{array}$ & $\begin{array}{l}\text { STATE HOSP } \\
\text { STATE HOSP } \\
\text { RBWD } 3\end{array}$ \\
\hline
\end{tabular}

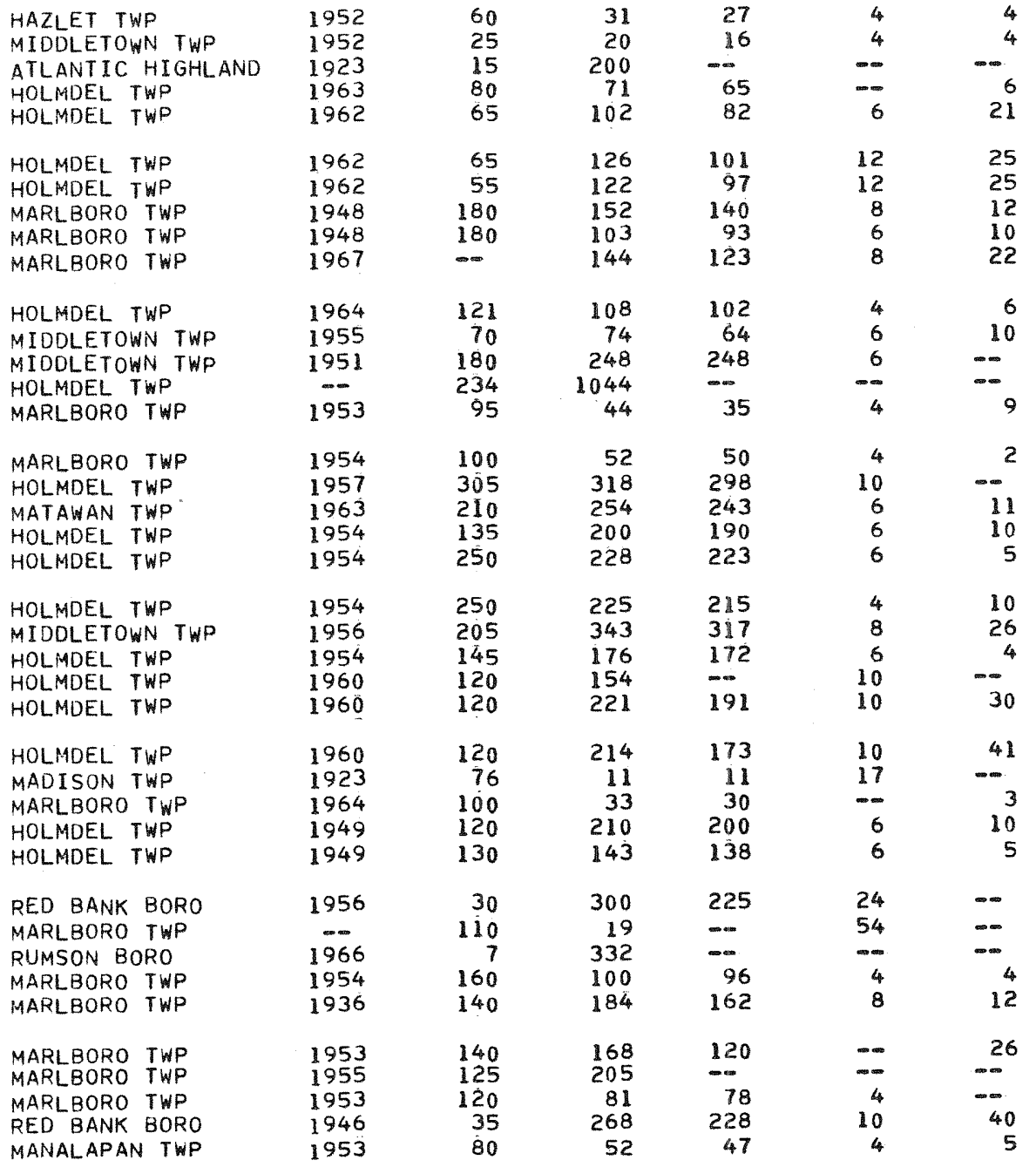


Table 7.--Construction data for wells developed in the Englishtown aquifer in Monmouth and Ocean Counties--Continued

\begin{tabular}{|c|c|c|c|c|c|c|c|c|c|c|}
\hline $\begin{array}{l}\text { MAP } \\
\text { NO }\end{array}$ & LOCATION & OWNFR & $\begin{array}{l}\text { LOCAL } \\
\text { WELLL } \\
\text { NUMBER }\end{array}$ & MUNICIPALITY & $\begin{array}{l}\text { DATE } \\
\text { DRILLED } \\
\text { (YEAR) }\end{array}$ & $\begin{array}{l}\text { ALTI- } \\
\text { TUDE- } \\
\text { OF LSD } \\
\text { (FT) }\end{array}$ & $\begin{array}{l}\text { WELL } \\
\text { DEPTH } \\
\text { (FT) }\end{array}$ & $\begin{array}{l}\text { CASING } \\
\text { DEPTH } \\
\text { (FT) }\end{array}$ & $\begin{array}{l}\text { CASING } \\
\text { DIAM- } \\
\text { ETER } \\
\text { (IN) }\end{array}$ & $\begin{array}{l}\text { LENGTH } \\
\text { OF WELL } \\
\text { OPEN TO } \\
\text { AQUIFER } \\
\text { (FEET) }\end{array}$ \\
\hline $\begin{array}{l}41 \\
42 \\
43 \\
44 \\
45\end{array}$ & $\begin{array}{l}401937 N 0741428.1 \\
401933 N_{0} 741336.1 \\
401927 N 0735842.1 \\
401948 N 0741541.1 \\
401918 N 0741507.1\end{array}$ & $\begin{array}{l}\text { MARLBORO S HOSP } \\
\text { MARLBORO S HOSP } \\
\text { MON BCH CLD STR } \\
\text { H\&L FARMS } \\
\text { R. E MORGAN }\end{array}$ & $\begin{array}{l}\text { STATE HOSP } 4 \\
\text { STATE HOSP } 5 \\
\text { MBCS } 2 \\
\\
--\end{array}$ & $\begin{array}{ll}\text { MARLBORO TWP } \\
\text { MARLBORO TWP } \\
\text { MONMOUTH } \\
\text { BCH BORO } \\
\text { MARLBORO TWP } \\
\text { MARLBORO TWP }\end{array}$ & $\begin{array}{l}-- \\
1935 \\
1961 \\
1951 \\
1947\end{array}$ & $\begin{array}{l}125 \\
135 \\
10 \\
160 \\
140\end{array}$ & $\begin{array}{l}124 \\
144 \\
430 \\
206 \\
175\end{array}$ & $\begin{array}{l}90 \\
110 \\
390 \\
197 \\
160\end{array}$ & $\begin{array}{r}6 \\
6 \\
10 \\
6 \\
6\end{array}$ & $\begin{array}{r}1 \\
30 \\
40 \\
9 \\
15\end{array}$ \\
\hline $\begin{array}{l}46 \\
47 \\
48 \\
49 \\
50\end{array}$ & $\begin{array}{l}401858 N_{0} 741506.1 \\
401803 N_{0} 740814.1 \\
401710 N 0741925.1 \\
401906 N_{0} 741514.1 \\
401742 N 0740201.1\end{array}$ & $\begin{array}{l}\text { HENRY HIGGINS } \\
\text { M ROSENBERG } \\
\text { J P FOCARILE } \\
\text { VILLAGE WC } \\
\text { OLD ORCHARD C C }\end{array}$ & $\begin{array}{l}\text { ROSENBERG } 1 \\
\text { FOCARILE } \\
\text { VILLAGE } 215 \\
\text { OLD ORCHARD } 1\end{array}$ & $\begin{array}{l}\text { MARLBORO TWP } \\
\text { COLTS NECK TWP } \\
\text { MANALAPAN TWP } \\
\text { MARLBORO TWP } \\
\text { WEST LONG BRANCH }\end{array}$ & $\begin{array}{l}1954 \\
1957 \\
1964 \\
1964 \\
1952\end{array}$ & $\begin{array}{r}170 \\
80 \\
95 \\
120 \\
40\end{array}$ & $\begin{array}{l}176 \\
342 \\
116 \\
215 \\
425\end{array}$ & $\begin{array}{l}171 \\
322 \\
100 \\
186 \\
360\end{array}$ & $\begin{array}{l}4 \\
8 \\
4 \\
8 \\
8\end{array}$ & $\begin{array}{r}5 \\
20 \\
6 \\
29 \\
20\end{array}$ \\
\hline $\begin{array}{l}51 \\
52 \\
53 \\
54 \\
55\end{array}$ & $\begin{array}{l}401747 \text { No } 741221.1 \\
401657 N 0741944.1 \\
401720 N 0740315.1 \\
401712 N 0741428.1 \\
401718 N 0742217.1\end{array}$ & $\begin{array}{l}\text { CEDAR DR EL SCH } \\
\text { GEORGE THOMPSON } \\
\text { R H MACY \& CO } \\
\text { E R OURAND } \\
\text { TAYLOR PALMER }\end{array}$ & BAMBERGER TEST & $\begin{array}{l}\text { COLTS NECK TWP } \\
\text { MANALAPAN TWP } \\
\text { EATONTOWN BORO } \\
\text { FREEHOLD TWP } \\
\text { MANALAPAN TWP }\end{array}$ & $\begin{array}{l}1963 \\
1954 \\
1957 \\
1960 \\
1955\end{array}$ & $\begin{array}{r}122 \\
100 \\
70 \\
180 \\
90\end{array}$ & $\begin{array}{r}233 \\
86 \\
430 \\
257 \\
60\end{array}$ & $\begin{array}{r}213 \\
83 \\
416 \\
249 \\
53\end{array}$ & $\begin{array}{r}-- \\
4 \\
6 \\
6 \\
4\end{array}$ & $\begin{array}{r}20 \\
3 \\
14 \\
8 \\
--\end{array}$ \\
\hline $\begin{array}{l}56 \\
57 \\
58 \\
59 \\
60\end{array}$ & $\begin{array}{l}401644 N 0741929.1 \\
401624 N 0741502.1 \\
401719 N 0741016.1 \\
401628 N 0742026.1 \\
401710 N 0742220.1\end{array}$ & $\begin{array}{l}\text { TENNEINT ORCH I } \\
\text { SO GULF UTIL } \\
\text { ATLANTIC TWP SC } \\
\text { K A JADASSOHN } \\
\text { ROY H KIRSHNER }\end{array}$ & $\begin{array}{l}\text { SO GULF } \overline{1} \\
\text { ATLANTIC } \mathrm{SCH} 1 \\
-- \\
--\end{array}$ & $\begin{array}{l}\text { MANALAPAN TWP } \\
\text { FREEHOLD TWP } \\
\text { COLTS NECK TWP } \\
\text { MANALAPAN TWP } \\
\text { MANALAPAN TWP }\end{array}$ & $\begin{array}{l}1954 \\
1964 \\
1954 \\
1956 \\
1953\end{array}$ & $\begin{array}{r}130 \\
200 \\
86 \\
120 \\
95\end{array}$ & $\begin{array}{r}167 \\
356 \\
280 \\
115 \\
84\end{array}$ & $\begin{array}{r}157 \\
327 \\
270 \\
110 \\
80\end{array}$ & $\begin{array}{l}6 \\
8 \\
6 \\
4 \\
4\end{array}$ & $\begin{array}{r}10 \\
29 \\
10 \\
5 \\
4\end{array}$ \\
\hline $\begin{array}{l}61 \\
62 \\
63 \\
64 \\
65\end{array}$ & $\begin{array}{l}401654 N 0741736.1 \\
401710 N 0742147.1 \\
401618 N 0741452.1 \\
401547 N 0741640.1 \\
401545 N 0741603.1\end{array}$ & $\begin{array}{l}\text { FREEHOLD TWP WD } \\
\text { ABE COHEN } \\
\text { FRANK GUMINA } \\
\text { MONMOUTH COUNTY } \\
\text { AM KARAGHEUSIAN }\end{array}$ & $\begin{array}{l}\text { POINT IVY } 1 \\
\text { GUMINA } 1-- \\
\text { MO COCH } 2 \\
1\end{array}$ & $\begin{array}{l}\text { FREEHOLD TWP } \\
\text { MANALAPAN TWP } \\
\text { FREEHOLD TWP } \\
\text { FREEHOLD BORO } \\
\text { FREEHOLD BORO }\end{array}$ & $\begin{array}{l}1967 \\
1953 \\
1953 \\
1954 \\
1948\end{array}$ & $\begin{array}{r}130 \\
84 \\
190 \\
170 \\
150\end{array}$ & $\begin{array}{r}212 \\
78 \\
324 \\
323 \\
323\end{array}$ & $\begin{array}{r}150 \\
73 \\
304 \\
307 \\
303\end{array}$ & $\begin{array}{r}12 \\
6 \\
6 \\
8 \\
8\end{array}$ & $\begin{array}{r}50 \\
5 \\
20 \\
16 \\
20\end{array}$ \\
\hline $\begin{array}{l}66 \\
67 \\
68 \\
69 \\
70\end{array}$ & $\begin{array}{l}401557 N 0742318.2 \\
401600 N 0741204.1 \\
401505 N 0741710.1 \\
401545 N 0742536.1 \\
401518 N 0742230.1\end{array}$ & $\begin{array}{l}\text { BOY SCOUTS AMER } \\
\text { MR SCATUORCHIO } \\
\text { F J MOREAU } \\
\text { GEORGE MOUNT } \\
\text { MANAALAPAN W C }\end{array}$ & $\begin{array}{l}\text { QUAIL HILL } 1 \\
\text { SCATUORCHIO } 1 \\
\text { MOUNT } 2 \\
\text { MANALAPAN } 1\end{array}$ & $\begin{array}{l}\text { MANALAPAN TWP } \\
\text { COLTS NECK TWP } \\
\text { FREEHOLD BORO } \\
\text { MILLSTONE TWP } \\
\text { MANALAPAN TWP }\end{array}$ & $\begin{array}{l}1967 \\
1950 \\
1953 \\
1967\end{array}$ & $\begin{array}{l}250 \\
140 \\
185 \\
135 \\
122\end{array}$ & $\begin{array}{r}241 \\
250 \\
300 \\
52 \\
185\end{array}$ & $\begin{array}{l}231 \\
238 \\
-- \\
46 \\
125\end{array}$ & $\begin{array}{r}6 \\
6 \\
-\infty \\
-\infty \\
10\end{array}$ & $\begin{array}{r}12 \\
-\infty \\
60\end{array}$ \\
\hline $\begin{array}{l}71 \\
72 \\
73 \\
74 \\
75\end{array}$ & $\begin{array}{l}401443 N 0742320.1 \\
401511 N 0742021.1 \\
401500 N 0741514.1 \\
401429 N 0741254.1 \\
401323 N 0742824.1\end{array}$ & $\begin{array}{l}\text { S WURTZEL } \\
\text { C BORDUNOVICH } \\
\text { BROCKWAY GLASS } \\
\text { SEASIDE INVEST } \\
\text { LEON VASSEUR }\end{array}$ & $\begin{array}{r}-- \\
\text { BROCKWAY } 1 \\
-- \\
--\end{array}$ & $\begin{array}{l}\text { MILLSTONE TWP } \\
\text { MANALAPAN TWP } \\
\text { FREEHOLD TWP } \\
\text { HOWELL TWP } \\
\text { ROOSEVELT BORO }\end{array}$ & $\begin{array}{l}1953 \\
1954 \\
1956 \\
1963 \\
1952\end{array}$ & $\begin{array}{l}180 \\
160 \\
130 \\
160 \\
140\end{array}$ & $\begin{array}{r}178 \\
170 \\
260 \\
380 \\
96\end{array}$ & $\begin{array}{r}174 \\
166 \\
240 \\
364 \\
92\end{array}$ & $\begin{array}{l}6 \\
4 \\
8 \\
4 \\
4\end{array}$ & $\begin{array}{r}4 \\
4 \\
20 \\
16 \\
4\end{array}$ \\
\hline $\begin{array}{l}76 \\
77 \\
78 \\
79 \\
80\end{array}$ & $\begin{array}{l}401333 N 0742640.1 \\
401331 N 0741944.1 \\
401426 N 0741631.1 \\
401323 N 0743118.1 \\
401412 N 0741606.2\end{array}$ & $\begin{array}{l}\text { ABE KUHL } \\
\text { CLAYTON WM D } \\
\text { D MAYK } \\
\text { HENRY WIKOFF } \\
\text { FREEHOLD TWP WD }\end{array}$ & $\begin{aligned} & \text { CLAYTON } \overline{2} \\
&=- \\
&-- \\
& \text { KOENIG LANE } 2\end{aligned}$ & $\begin{array}{l}\text { MILLSTONE TWP } \\
\text { MANALAPAN TWP } \\
\text { FREEHOLD TWP } \\
\text { MILLSTONE TWP } \\
\text { FREEHOLD TWP }\end{array}$ & $\begin{array}{l}1956 \\
1955 \\
1949 \\
1953 \\
1966\end{array}$ & $\begin{array}{l}230 \\
180 \\
145 \\
115 \\
130\end{array}$ & $\begin{array}{r}160 \\
333 \\
310 \\
50 \\
307\end{array}$ & $\begin{array}{r}154 \\
304 \\
300 \\
47 \\
262\end{array}$ & $\begin{array}{r}4 \\
10 \\
6 \\
4 \\
6\end{array}$ & $\begin{array}{r}6 \\
29 \\
10 \\
3 \\
45\end{array}$ \\
\hline
\end{tabular}


ALLENHURST D AWD 2 ASBURY PARK W D APWD 4 MONMOUTH CON WC WHITESVILLE 3 MONMOUTH CON WC OCEAN GROVE 20

FARMINGDALE W O FARMINGDALE I FARMINGDALE W FARMINGOALE 2 FARMINGDALE D FARMINGDALE 4 FARMINGDALE W D FARMINGDALE MRS ERRICKS̃ON

$-\infty$

MR VANHISE
BELMAR BORO WD BWD 4 ELEC DEPT OF ARMY IMPERIAL PARKZ DE

BELMAR BORO WD BWD 5 SUB BELMAR BORO WD BWD 1 ELEC BELMAR BORO WD BWD 3 SUB BELMAR BORO WD BWD 6 SUR BELMAR BORO WD BWD 1 SUB

BELMAR BORO WD BWD 4 SUB BELMAR BORO WD BWD 2 ELEC BELMAR BORO WD BWD 3 ELEC WALL TWP W D$$
\text { WALL TWP WD RT } 34 \text { WELL }
$$$$
\text { C I SMITH }
$$
I) FREEHOLD B ED BOARD ED $\begin{array}{llll}\text { SPRING LAKE W } & \text { SLWD } & 4 \\ \text { SPRING LAKE W } & \text { D SLWD } 3\end{array}$

ALDRICH W CO ALDRICH W CO 4 US GEOL SURVEY ALLAIRE S $P$ C SPRING LK HT WD SPRING LK HGT2 SPRING LAKE W D SLWD 1

SPRING LAKE W D SLWD 2 JACKSON TWP MUA JACKSON 2 WALL TWP W D ALLENWOOD 1
WALL TWP W D ALLENWOOD 2
ALLENHURST BORO ALLENHURST BORO ASBURY PARK ASBURY PARK

NEPTUNE TWP

FARMINGDALE BORO FARMINGDALE BORO FARMINGDALE BORO

U FREEHOLD TWP

U FREEHOLD TWP BELMAR BORO WALL TWP FEEHOLD TWP

BELMAR BORO BELMAR BORO BELMAR BORO BELMAR BORO BELMAR BORO

BELMAR BORO BELMAR BORO BELMAR BORO BELMAR BORO WALL TWP

\section{WALL TWP}

FREEHOLD TWP SPRING LAKE BORO PPRING LAKE BORO

\section{HOWELL TWP}

WALL TWP

SPNG LK HGTS BO SPRING LAKE BORO SPRING LAKE BORO O FREEHOLD TWP JACKSON TWP WALL TWP

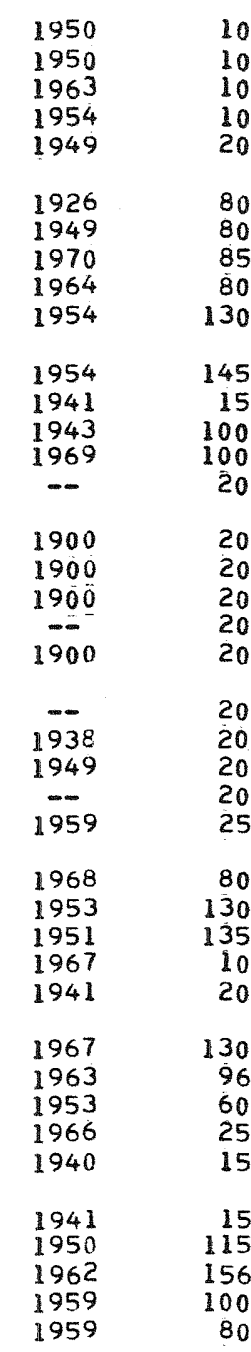

45

40

68
35

30

60 
Table 7--Construction data for we11s developed in the

Englishtown aquifer in Monmouth and Ocean Counties--Continued

\begin{tabular}{|c|c|c|c|c|c|c|c|c|c|c|}
\hline $\begin{array}{l}\text { MAP } \\
\text { NO }\end{array}$ & LOCATION & $O W N_{E}=R$ & $\begin{array}{l}\text { LOCAL } \\
\text { WELL } \\
\text { NUMBER }\end{array}$ & MUNICIPALITY & $\begin{array}{l}\text { DATE } \\
\text { DRILLED } \\
\text { (YEAR) }\end{array}$ & $\begin{array}{l}\text { ALTI- } \\
\text { TUDE- } \\
\text { OF LSD } \\
\text { (FT) }\end{array}$ & $\begin{array}{l}\text { WELL } \\
\text { DEPTH } \\
\text { (FT). }\end{array}$ & $\begin{array}{l}\text { CASING } \\
\text { DEPTH } \\
(F T)\end{array}$ & $\begin{array}{l}\text { CASING } \\
\text { DIAM- } \\
\text { ETER } \\
(I N)\end{array}$ & $\begin{array}{l}\text { OF WELL } \\
\text { OPEN TO } \\
\text { AQUIFER } \\
\text { (FEET) }\end{array}$ \\
\hline $\begin{array}{l}121 \\
122 \\
123 \\
124 \\
125\end{array}$ & $\begin{array}{l}400804 N_{0} 740227.1 \\
400800 N 0740231.1 \\
400752 N 0743454.1 \\
400742 N 0741639.1 \\
400745 N 0741333.1\end{array}$ & $\begin{array}{l}\text { SEA GIRT W D } \\
\text { SEA GIRT W D } \\
\text { ATLEE ZURLO } \\
\text { JACKSON TWP MUA } \\
\text { HOWELL TWP BD }\end{array}$ & $\begin{array}{l}\text { SGWD } 5 \\
\text { SGWD } 4 \\
\text { JACKSON } 4 \\
\text { KENT RD }\end{array}$ & $\begin{array}{l}\text { SEA GIRT BORO } \\
\text { SEA GIRT BORO } \\
\text { U FREEHOLD TWP } \\
\text { JACKSON TWP } \\
\text { HOWELL TWP }\end{array}$ & $\begin{array}{l}1963 \\
1949 \\
1952 \\
1965 \\
1955\end{array}$ & $\begin{array}{r}20 \\
18 \\
90 \\
80 \\
110\end{array}$ & $\begin{array}{l}710 \\
715 \\
109 \\
500 \\
582\end{array}$ & $\begin{array}{r}660 \\
685 \\
99 \\
448 \\
558\end{array}$ & $\begin{array}{r}10 \\
10 \\
4 \\
8 \\
6\end{array}$ & $\begin{array}{r}55 \\
-10 \\
52 \\
--\end{array}$ \\
\hline $\begin{array}{l}126 \\
127 \\
128 \\
129 \\
130\end{array}$ & $\begin{array}{l}400803 N_{0} 740229.1 \\
400657 N_{0} 741715.1 \\
400712 N_{0} 741512.1 \\
400645 N_{0} 740345.1 \\
400636 N_{0} 741515.1\end{array}$ & $\begin{array}{l}\text { SEA GIRT W D } \\
\text { JACKSON TWP MUA } \\
\text { JACKSON TWP MUA } \\
\text { BRIELLE WATER D } \\
\text { ST GABRIELS COL }\end{array}$ & $\begin{array}{l}\text { SGWD } 3 \\
\text { JACKSON } 3 \\
\text { JACKSON } 1 \\
\text { BWD } 2 \\
\text { ST GABRIELS } 1\end{array}$ & $\begin{array}{l}\text { SEA GIRT BORO } \\
\text { JACKSON TWP } \\
\text { JACKSON TWP } \\
\text { BRIELLE BORO } \\
\text { LAKEWOOD TWP }\end{array}$ & $\begin{array}{l}1921 \\
1962 \\
1961 \\
1950 \\
1957\end{array}$ & $\begin{array}{r}20 \\
140 \\
110 \\
33 \\
70\end{array}$ & $\begin{array}{l}760 \\
559 \\
557 \\
750 \\
530\end{array}$ & $\begin{array}{l}730 \\
513 \\
511 \\
690 \\
--\end{array}$ & $\begin{array}{r}8 \\
10 \\
8 \\
12 \\
8\end{array}$ & $\begin{array}{l}-- \\
46 \\
46 \\
60 \\
--\end{array}$ \\
\hline $\begin{array}{l}131 \\
132 \\
133 \\
134 \\
135\end{array}$ & $\begin{array}{l}400555 N_{0} 740851.1 \\
400623 \mathrm{~N}^{2} 740429.1 \\
400614 \mathrm{~N}_{0} 741157.1 \\
400622 \mathrm{~N} 0741349.1 \\
400540 \mathrm{~N} 0741230.1\end{array}$ & $\begin{array}{l}\text { PARKWAY WC } \\
\text { BRIELLE WATER D } \\
\text { LAKEWOOD WC } \\
\text { LAKEWOOD W C } \\
\text { LAKESORE LAUNDR }\end{array}$ & $\begin{array}{l}\text { PARKWAY } 1 \\
\text { BWD } 3 \\
\text { LAKE WOOD } 9 \\
\text { LAKEWODO } 6 \\
\text { LAKESHORE LA } 1\end{array}$ & $\begin{array}{l}\text { HOWELL TWP } \\
\text { BRIELLE BORO } \\
\text { LAKEWOOD TWP } \\
\text { LAKEWOOD TWP } \\
\text { LAKEWOOD TWP }\end{array}$ & $\begin{array}{l}1958 \\
1967 \\
1968 \\
1960 \\
1950\end{array}$ & $\begin{array}{l}45 \\
90 \\
55 \\
70 \\
50\end{array}$ & $\begin{array}{l}646 \\
820 \\
698 \\
582 \\
612\end{array}$ & $\begin{array}{l}605 \\
770 \\
569 \\
521 \\
596\end{array}$ & $\begin{array}{r}8 \\
10 \\
8 \\
8 \\
6\end{array}$ & $\begin{array}{l}41 \\
50 \\
65 \\
61 \\
16\end{array}$ \\
\hline $\begin{array}{l}136 \\
137 \\
138 \\
139 \\
140\end{array}$ & $\begin{array}{l}400516 N 0741255.1 \\
400516 N 0741255.2 \\
400515 N 0741251.2 \\
400515 N 0741251.1 \\
400500 N 0741108.1\end{array}$ & $\begin{array}{l}\text { LAKEWOOD W } \\
\text { LAKEWOOD W } \\
\text { LAKEWOOD } \\
\text { LAKEW } \\
\text { LAKEWOD W } \\
\text { LAKEWOOD } \\
\text { W } \\
C\end{array}$ & $\begin{array}{l}\text { LAKEWOOD WC } \\
\text { LAKEWOOD } 2 \\
\text { LAKEWOOD W } C \\
\text { LAKEWOOD } 5 \\
\text { LAKEWOOD }\end{array}$ & $\begin{array}{l}\text { LAKEWOOD TWP } \\
\text { LAKEWOOD TWP } \\
\text { LAKEWOOD TWP } \\
\text { LAKEWOOD TWP } \\
\text { LAKEWOOD TWP }\end{array}$ & $\begin{array}{l}1900 \\
1921 \\
1899 \\
1957 \\
1966\end{array}$ & $\begin{array}{l}35 \\
60 \\
30 \\
40 \\
30\end{array}$ & $\begin{array}{l}621 \\
625 \\
600 \\
604 \\
736\end{array}$ & $\begin{array}{l}-- \\
575 \\
-\infty \\
547 \\
725\end{array}$ & $\begin{array}{l}6 \\
8 \\
6 \\
8 \\
4\end{array}$ & $\begin{array}{l}-\infty \\
-\infty \\
-\infty \\
-\infty\end{array}$ \\
\hline $\begin{array}{l}141 \\
142 \\
143 \\
144 \\
145\end{array}$ & $\begin{array}{l}400459 N 0740359.1 \\
400454 N 0740413.1 \\
400450 N 0740410.1 \\
400450 N 0740410.2 \\
400450 N 0740410.3\end{array}$ & 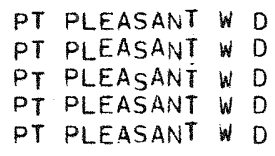 & $\begin{array}{l}\text { PPWD } \\
\text { PPWD } 6 \\
\text { PPWD } 2 \\
\text { PPWD } 1 \\
\text { PPWD }\end{array}$ & $\begin{array}{lll}\text { PT } & \text { PLSNT } & \text { BORO } \\
\text { PT } & \text { PLSNT } & \text { BORO } \\
\text { PT } & \text { PLSNT } & \text { BORO } \\
\text { PT PLSNT } & \text { BORO } \\
\text { PT PLSNT } & \text { BORO }\end{array}$ & $\begin{array}{l}1946 \\
1965 \\
1936 \\
1936 \\
1893\end{array}$ & $\begin{array}{l}15 \\
20 \\
15 \\
20 \\
10\end{array}$ & $\begin{array}{l}798 \\
790 \\
745 \\
825 \\
806\end{array}$ & $\begin{array}{l}748 \\
730 \\
715 \\
745 \\
746\end{array}$ & $\begin{array}{r}10 \\
8 \\
6 \\
8 \\
-\infty\end{array}$ & $\begin{array}{l}50 \\
68 \\
30 \\
-- \\
--\end{array}$ \\
\hline $\begin{array}{l}146 \\
147 \\
148 \\
149 \\
150\end{array}$ & $\begin{array}{l}400443 N_{0} 741352.1 \\
400435 N_{0} 740257.1 \\
400416 N_{0} 742701.1 \\
400354 N_{0} 741310.1 \\
400401 N_{0} 743200.2\end{array}$ & $\begin{array}{l}\text { LAKEWOOD W C } \\
\text { CENTRAL RR NJ } \\
\text { US GEOL SURVEY } \\
\text { LAKEWOOD W C } \\
\text { NEW EGYPT WC }\end{array}$ & $\begin{array}{l}\text { LAKEWOOD } 8 \\
\text { CENTRAL RR NJ } \\
\text { COLL MILLS TW1 } \\
\text { LAKEWOOD } 7 \\
1\end{array}$ & $\begin{array}{l}\text { LAKEWOOD TWP } \\
\text { BAY HEAD BORO } \\
\text { JACKSON TWP } \\
\text { LAKEWOOD TWP } \\
\text { PLUMSTED TWP }\end{array}$ & $\begin{array}{l}1965 \\
1930 \\
1964 \\
1964 \\
1907\end{array}$ & $\begin{array}{r}78 \\
9 \\
137 \\
85 \\
75\end{array}$ & $\begin{array}{l}758 \\
813 \\
427 \\
757 \\
239\end{array}$ & $\begin{array}{l}600 \\
793 \\
417 \\
697 \\
214\end{array}$ & $\begin{array}{l}8 \\
5 \\
6 \\
8 \\
6\end{array}$ & $\begin{array}{l}88 \\
20 \\
-- \\
-- \\
25\end{array}$ \\
\hline $\begin{array}{l}151 \\
152 \\
153 \\
154 \\
155\end{array}$ & $\begin{array}{l}400405 N 0740244.1 \\
400405 N 0740242.1 \\
400358 N 0740812.1 \\
400312 N 0741123.1 \\
400250 N 0741044.1\end{array}$ & $\begin{array}{l}\text { OCEAN CO } W C \\
\text { OCEAN CO } W \\
\text { BRADLEES CORP } \\
\text { S LAKEWOOD W } \\
\text { S LAKEWOOD }\end{array}$ & $\begin{array}{l}\text { BAY HEAD } 6 \\
\text { BAY HEAD } 5 \\
\text { BRADLEES WELL } \\
\text { S LAKE WOD } 3 \\
\text { S LAKEWOOD } 2\end{array}$ & $\begin{array}{l}\text { BAY HEAD BORO } \\
\text { BAY HEAD BORO } \\
\text { BRICK TWP } \\
\text { LAKEWOOD TWP } \\
\text { LAKEWOOD TWP }\end{array}$ & $\begin{array}{l}1950 \\
1947 \\
1969 \\
1966 \\
1963\end{array}$ & $\begin{array}{l}10 \\
10 \\
10 \\
45 \\
40\end{array}$ & $\begin{array}{l}818 \\
834 \\
710 \\
741 \\
762\end{array}$ & $\begin{array}{l}778 \\
775 \\
670 \\
673 \\
680\end{array}$ & $\begin{array}{r}8 \\
8 \\
12 \\
8 \\
8\end{array}$ & $\begin{array}{l}-- \\
- \\
40 \\
62\end{array}$ \\
\hline $\begin{array}{l}156 \\
157 \\
158 \\
159 \\
160\end{array}$ & $\begin{array}{l}400220 N 0741154.1 \\
400211 N 0740311.1 \\
400210 N 0740310.1 \\
395808 N 0740421.1 \\
395741 N 0740437.1 \\
395609 N 0741240.1\end{array}$ & $\begin{array}{l}\text { S LAKEWOOD W } \\
\text { OCEAN CO C } \\
\text { OCEAN CO } \\
\text { LAVALLETTE W } \\
\text { LAVALLETTE W D } \\
\text { US GEOL SURVEY }\end{array}$ & $\begin{array}{l}\text { S LAKEWOOD } 1 \\
\text { MANTOLOKING } 4 \\
\text { MANTOLOKING } 6 \\
\text { LWD } 2 \\
\text { LWD } 3 \\
\text { TOMS RIVER TW2 }\end{array}$ & $\begin{array}{l}\text { LAKEWOOD TWP } \\
\text { MANTOLOKING BORO } \\
\text { MANTOLOKING BORO } \\
\text { LAVALLETTE BORO } \\
\text { LAVALLETTE BORO } \\
\text { S TOMS RIVER BORO }\end{array}$ & $\begin{array}{l}1969 \\
1924 \\
1955 \\
1931 \\
1948 \\
1965\end{array}$ & $\begin{array}{r}90 \\
5 \\
5 \\
5 \\
7 \\
15\end{array}$ & $\begin{array}{r}817 \\
922 \\
906 \\
1136 \\
1180 \\
1146\end{array}$ & $\begin{array}{r}748 \\
900 \\
845 \\
1009 \\
1120 \\
1080\end{array}$ & $\begin{array}{l}8 \\
6 \\
8 \\
6 \\
8 \\
3\end{array}$ & $\begin{array}{r}65 \\
22 \\
-\infty \\
127 \\
60 \\
66\end{array}$ \\
\hline
\end{tabular}


along the shore area of southeastern Monmouth County (fig. 15). The altitude of the potentiometric surface was below sea level throughout eastern Monmouth County and northeastern Ocean County; the potentiometric surface in the Belmar-Spring Lake area was more than $80 \mathrm{ft}(24 \mathrm{~m})$ below sea level and in the vicinity of Lakewood was more than $20 \mathrm{ft}(6 \mathrm{~m})$ below sea leve1.

A second series of water-level measurements in the Englishtown aquifer in Monmouth, Ocean, and Burlington Counties was made in November 1970 (table 6). The altitude and configuration of this potentiometric surface is shown in figure 16. The regional decline of the potentiometric surface between 1959 and 1970 (fig. 10) was greater than the decline from 1900 to 1959. The heavy ground-water withdrawals along the coastal areas of southern Monmouth County and northern Ocean County and in the Lakewood area caused decline of $100 \mathrm{ft}(30 \mathrm{~m})$ or more during this period. The effects of the pumping in these areas extended as far west as Freehold, where 12 to $15 \mathrm{ft}(3.6$ to $4.6 \mathrm{~m})$ of decline occurred.

Continuous records of water-level changes in the confined part of the Englishtown aquifer became available in 1964, when the U.S. Geological Survey installed two observation wells as part of the cooperative statewide observation well network. One well was installed at Allaire State Park in southeastern Monmouth County and the other at Colliers Mills Hunting and Fishing Grounds in northwestern Ocean County. The well at Allaire State Park is situated approximately midway between the two main centers of pumpage; one near Lakewood and the other along the coast in southern Monmouth County. The water level in this well declined $50 \mathrm{ft}(15 \mathrm{~m})$ between February 1964 and February 1970 at an average annual rate of decline of $8 \mathrm{ft}(2.4 \mathrm{~m})$ per year (fig. 17). The net decline between February 1969 and February 1970 was $12 \mathrm{ft}(3.6 \mathrm{~m})$. As the observation well at Colliers Mills is considerably west of the Lakewood area, water-level declines recorded in this well (fig. 17) are considerably less than those seen at Allaire State Park. The water-level at Colliers Mills declined only about $8 \mathrm{ft}(2.4 \mathrm{~m})$ between February 1964 and February 1970; the average rate of decline over this period was $1.3 \mathrm{ft}(0.4 \mathrm{~m})$ per year. The water level declined $1.2 \mathrm{ft}(0.37$ m) between February 1969 and February 1970.

The Lakewood Water Company installed an observation well southeast of Lakewood in late 1966. Continuous records of water levels in this well have been kept by the company since that time (fig. 17). The measurements show an almost continuous water-level decline of $81 \mathrm{ft}(24.7 \mathrm{~m})$ from January 1967 to September 1970.

\section{Ground-water Withdrawals}

Ground-water withdrawals from the Englishtown aquifer in Monmouth and Ocean Counties are dominantly for public supply (fig. 18). Domestic pumpage is not known but is probably smal1. Because shallower aquifers are capable of yielding quantities of water suitable for domestic purposes, it is not 


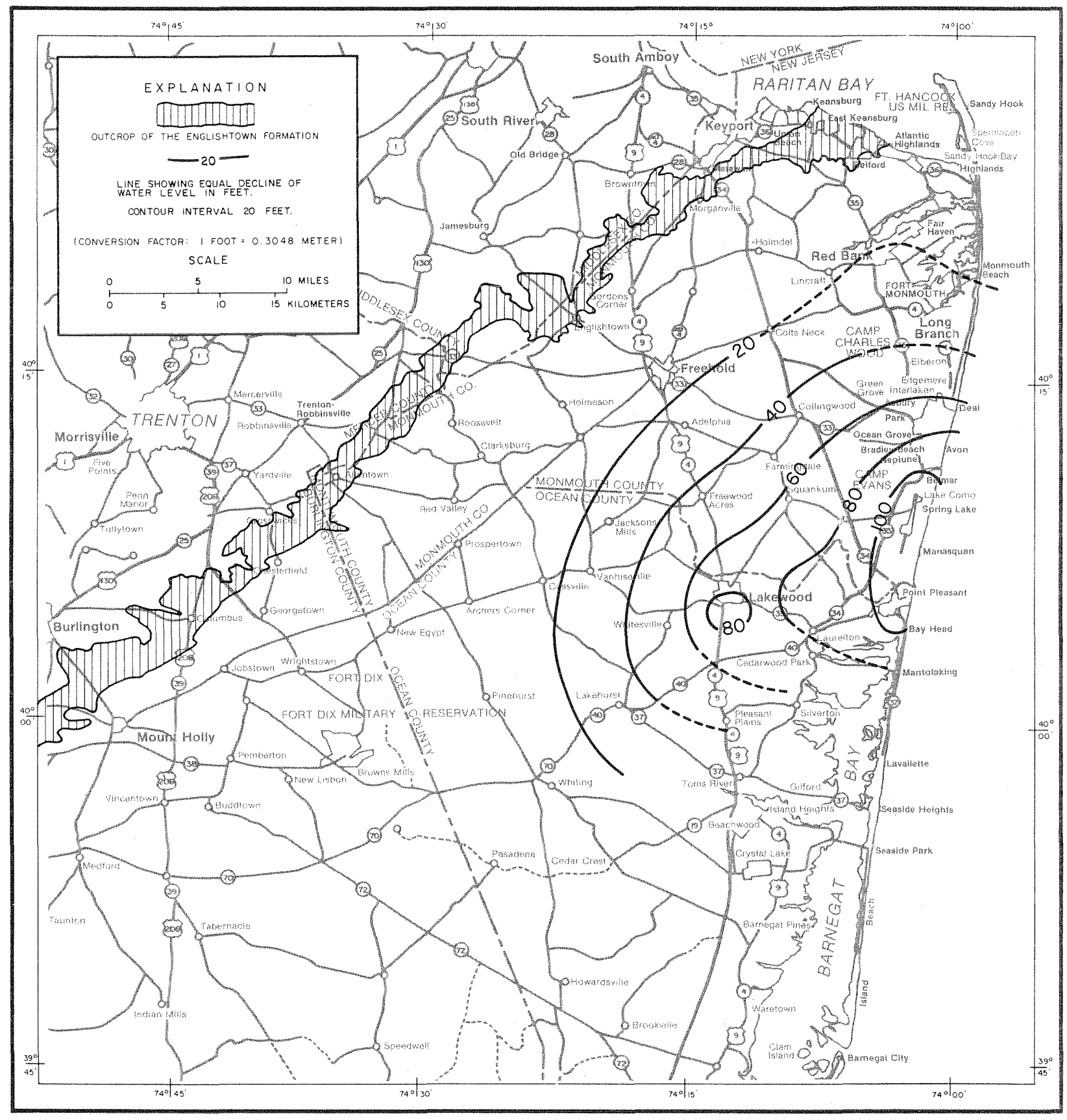

FIGURE 15. --WATER-LEVEL DECLINE BETWEEN ABOUT 1900 AND JANUARY 1959 IN THE ENGLISHTOWN AQUIFER IN MONMOUTH AND NORTHERN OCEAN COUNTIES, N.J. 


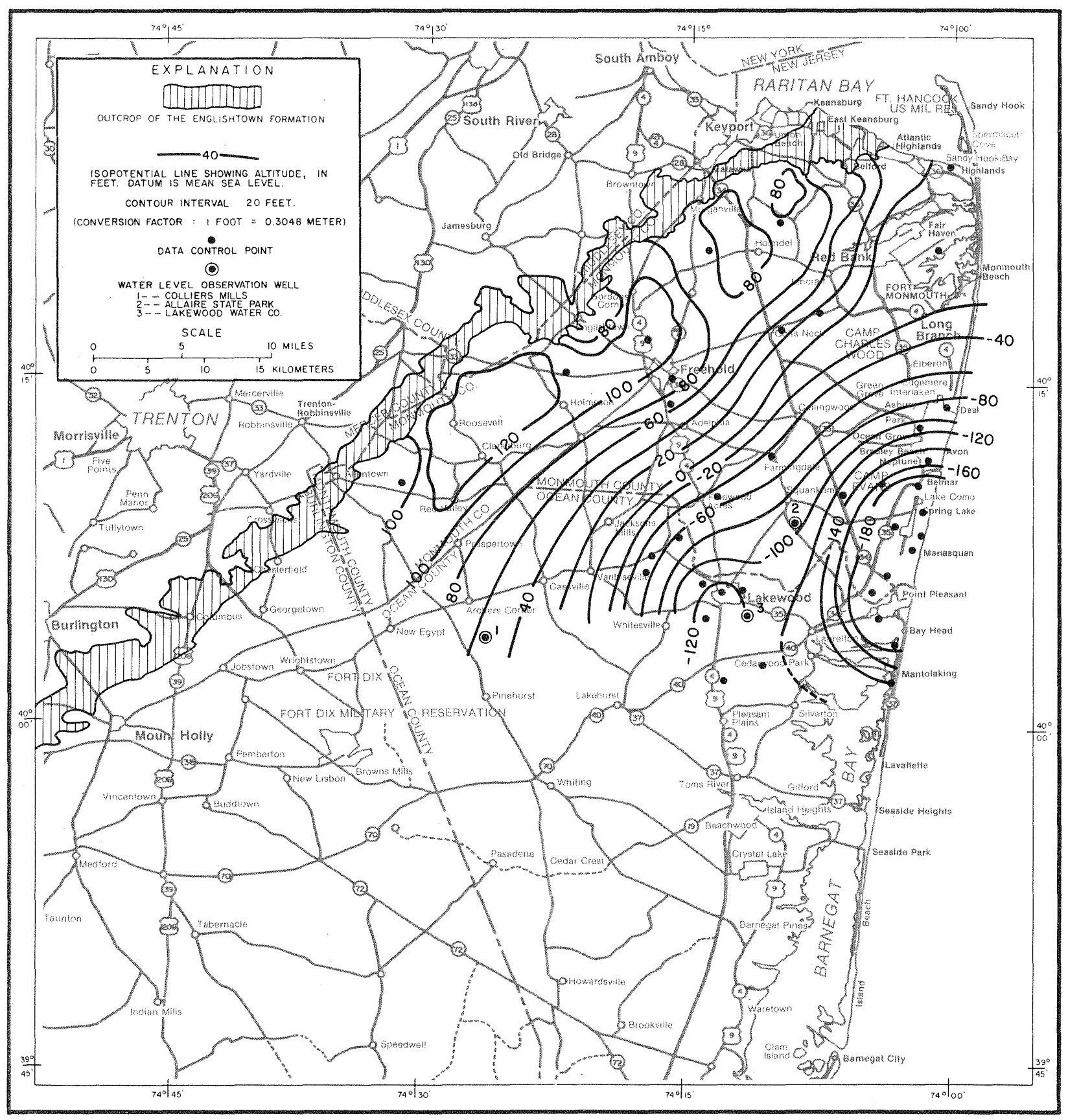

FIGURE 16. --ALTITUDE OF THE POTENTIOMETRIC SURFACE IN THE ENGLISHTOWN AQUIFER IN NOVEMBER 1970 IN MONMOUTH AND NORTHERN OCEAN COUNTIES, N.J. 


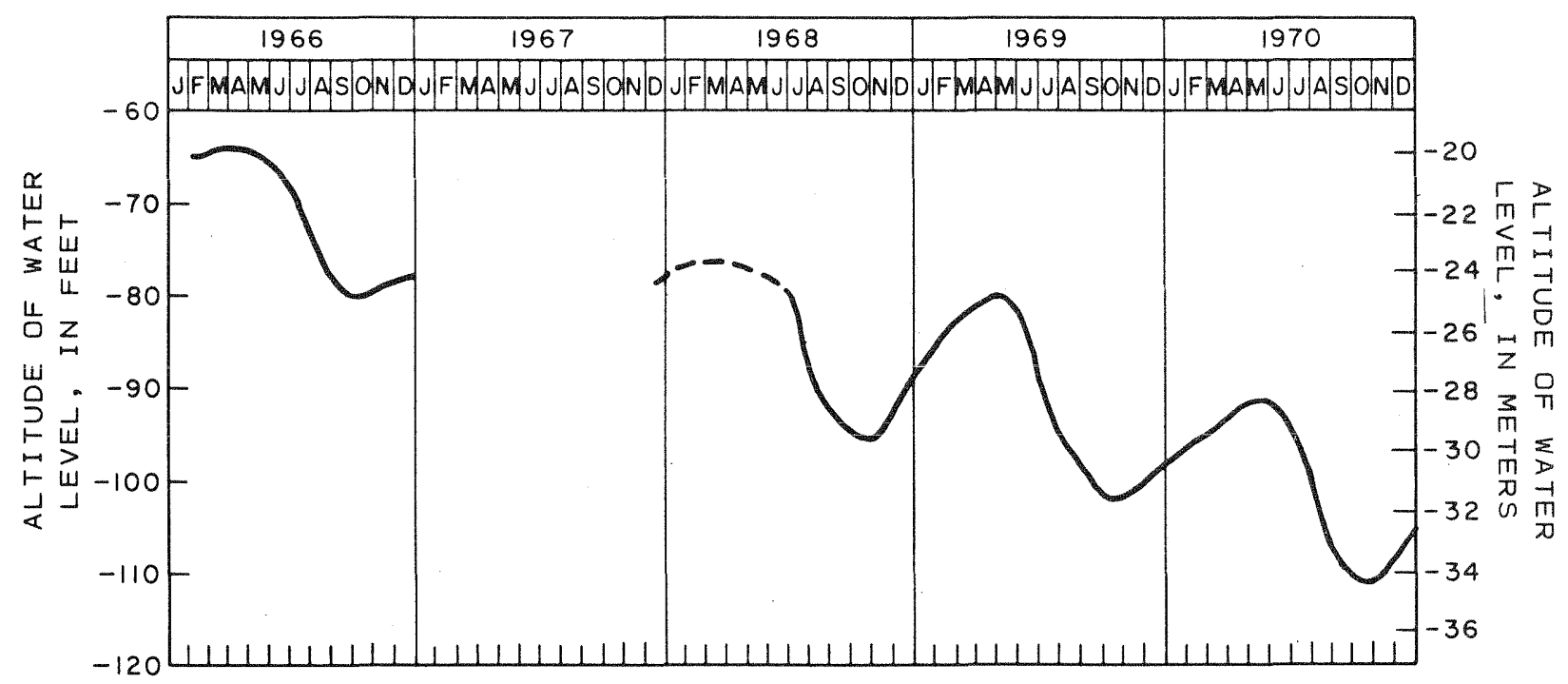

A. ALLAire state park, u.s.g.s. observation WELL, MONMOUTH COUNTY, N.J.

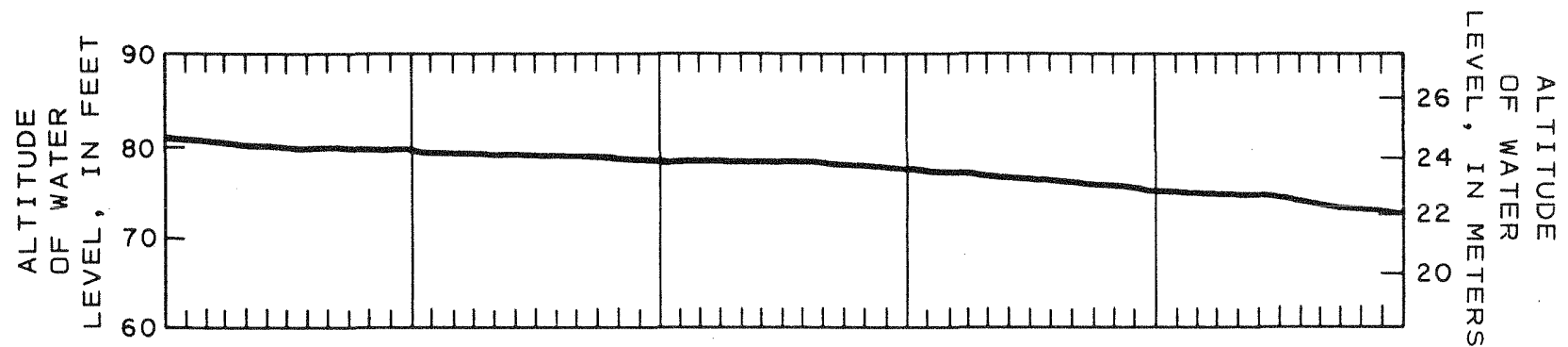

B. COLLIERS MILLS, U.S.G.S. OBSERVATION WELL TW 1, OCEAN COUNTY, N.J.

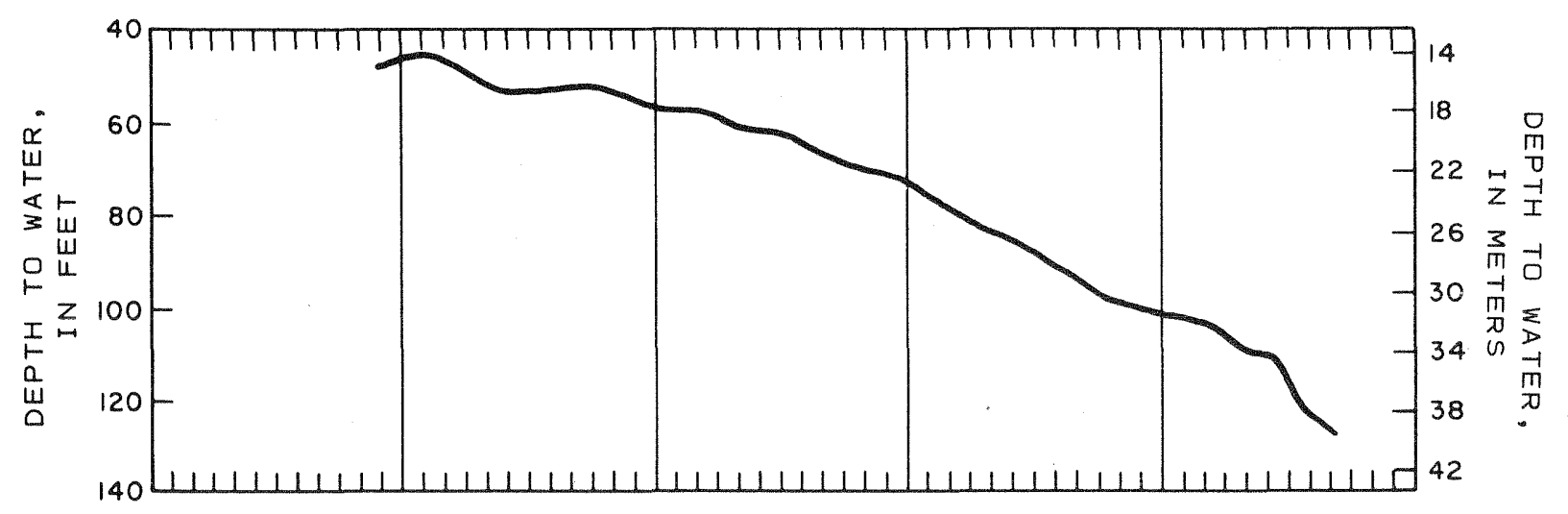

C. LAKEWOOD WATER COMPANY OBSERVATION WELL, LAKEWOOD, OCEAN COUNTY,N.J.

FIGURE 17. --HYDROGRAPHS OF OBSERVATION WELLS TAPPING THE ENGLISHTOWN AQUIFER IN MONMOUTH AND NORTHERN OCEAN COUNTIES, N.J. 


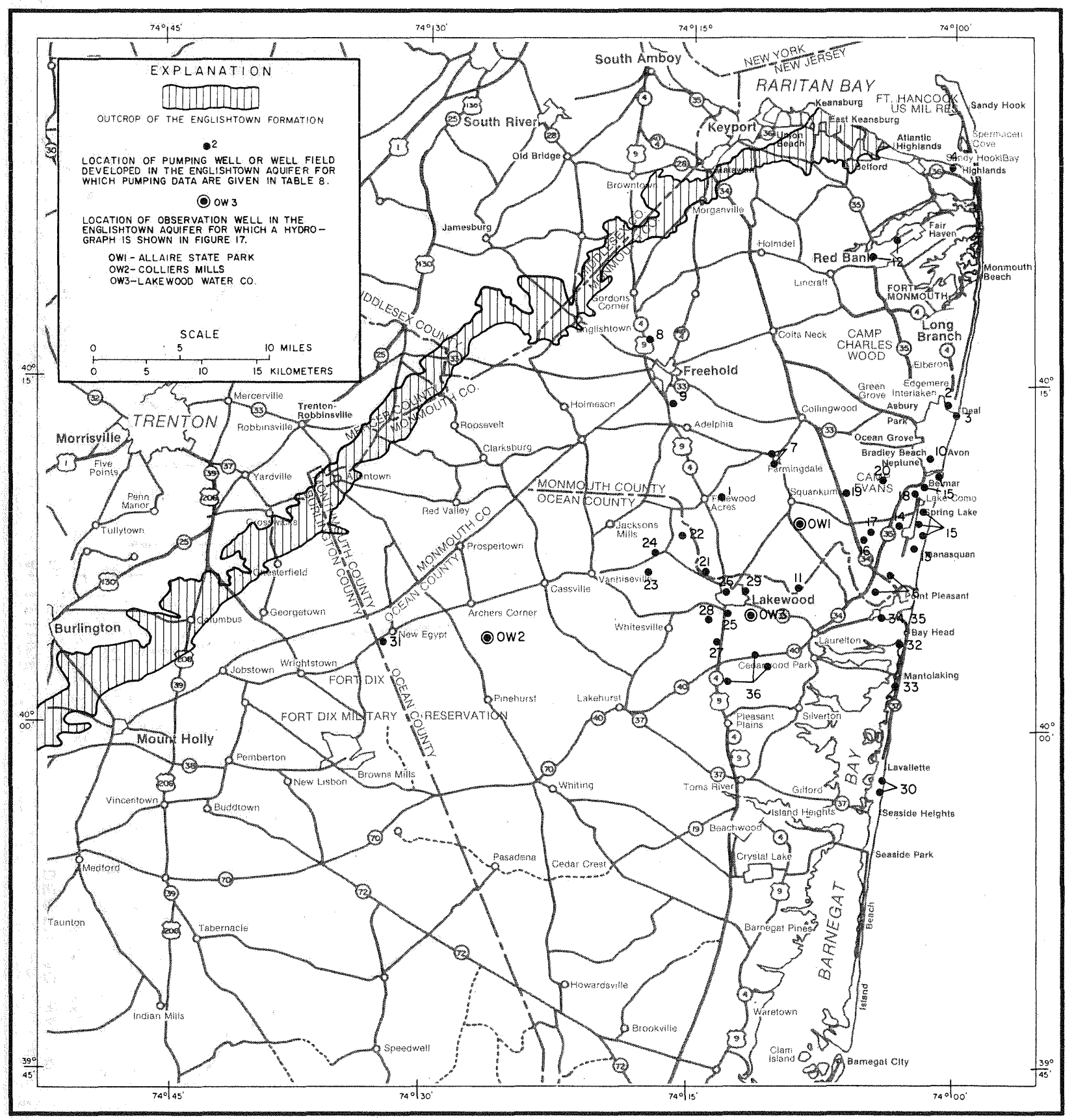

FIGURE 18. - -LOCATION OF PUMPING WELLS LISTED IN TABLE 8 AND OBSERVATION WELLS DESCRIBED IN FIGURE 17. 
necessary for these users to tap the Englishtown. Total withdrawals from the Englishtown in the area of investigation for industrial, irrigation, commercial and institutional uses are also minor and in most cases have not been considered (figure 19).

Water for public supply was pumped from the Englishtown aquifer in the two-county area at an average rate of about $5.5 \mathrm{Mgal} / \mathrm{d}\left(0.24 \mathrm{~m}^{3} / \mathrm{s}\right)$ in 1959 (table 8). By 1970 the rate of withdrawal had increased by approximately 80 percent, to about $9.5 \mathrm{Mgal} / \mathrm{d}\left(0.4 \mathrm{~m}^{3} / \mathrm{s}\right)$. Nearly 80 percent of the withdrawals was from an area of roughly $100 \mathrm{mi}^{2}\left(259 \mathrm{~km}^{2}\right)$, extending from Asbury Park southwest to the vicinity of Lakewood and south to the Point pleasant area. This is about one-seventh of the total area covered by this study.

The greatest increase in the rate of withdrawal from the Englishtown between 1959 and 1970 occurred in Ocean County. The average annual rate of pumping in 1959 was about $1.75 \mathrm{Mgal} / \mathrm{d}\left(0.07 \mathrm{~m}^{3} / \mathrm{s}\right)$. The 1970 rate of withdrawal was $4.67 \mathrm{Mgal} / \mathrm{d}(0.20 \mathrm{~m} 3 / \mathrm{s})$, an increase of almost 268 percent of the 1959 rate. Nearly al1 of the increase in withdrawals from the Englishtown aquifer in Ocean County has been from the area around Lakewood in Jackson and Lakewood Townships (table 8). In Monmouth County, the average annual rate of withdrawal for public supply increased only about 34 percent from $3.46 \mathrm{Mgal} / \mathrm{d}\left(0.15 \mathrm{~m}^{3} / \mathrm{s}\right)$ in 1959 to $4.67\left(0.20 \mathrm{~m}^{3} / \mathrm{s}\right)$ in 1970 (table 8). Nearly 60 percent [about $0.7 \mathrm{Mgal} / \mathrm{d}\left(0.03 \mathrm{~m}^{3} / \mathrm{s}\right)$ ] of the rate increase occurred in Wa11 Township in the southeastern part of the county. The remainder of the increased rate of pumping reflects increases throughout the rest of the county.

\section{Confining Layer Geometry}

The Englishtown Formation is bounded above and below by sequences of sandy to clayey silts and silty clays. The underlying sequence of sediments, which form the lower confining bed of the Englishtown aquifer, includes the Merchantville Formation and the Woodbury Clay. The combined thickness of the two formations ranges from less than $100 \mathrm{ft}(30 \mathrm{~m})$ in northern Monmouth County to more than $300 \mathrm{ft}(91 \mathrm{~m})$ in southeastern Monmouth County (fig. 2). It has an average thickness of about $180 \mathrm{ft}(55 \mathrm{~m})$ throughout most of northern Ocean County.

The sequence of fine-grained sediments above the Englishtown in the study area includes the Marshalltown Formation and the finer grained lower part of the Wenonah Formation. These sediments act as the upper confining bed of the aquifer. The thickness of the Marshalltown is relatively uniform throughout the area of investigation, ranging from 10 to $20 \mathrm{ft}$ ( 3 to $6 \mathrm{~m}$ ). As much as $80 \mathrm{ft}(24 \mathrm{~m})$ of the Wenonah is included in the thickness of the upper confining bed. The total thickness of this confining layer ranges from about $12 \mathrm{ft}(6 \mathrm{~m})$ in northern Monmouth County to $100 \mathrm{ft}(30 \mathrm{~m})$ in central Ocean County (fig. 20). 


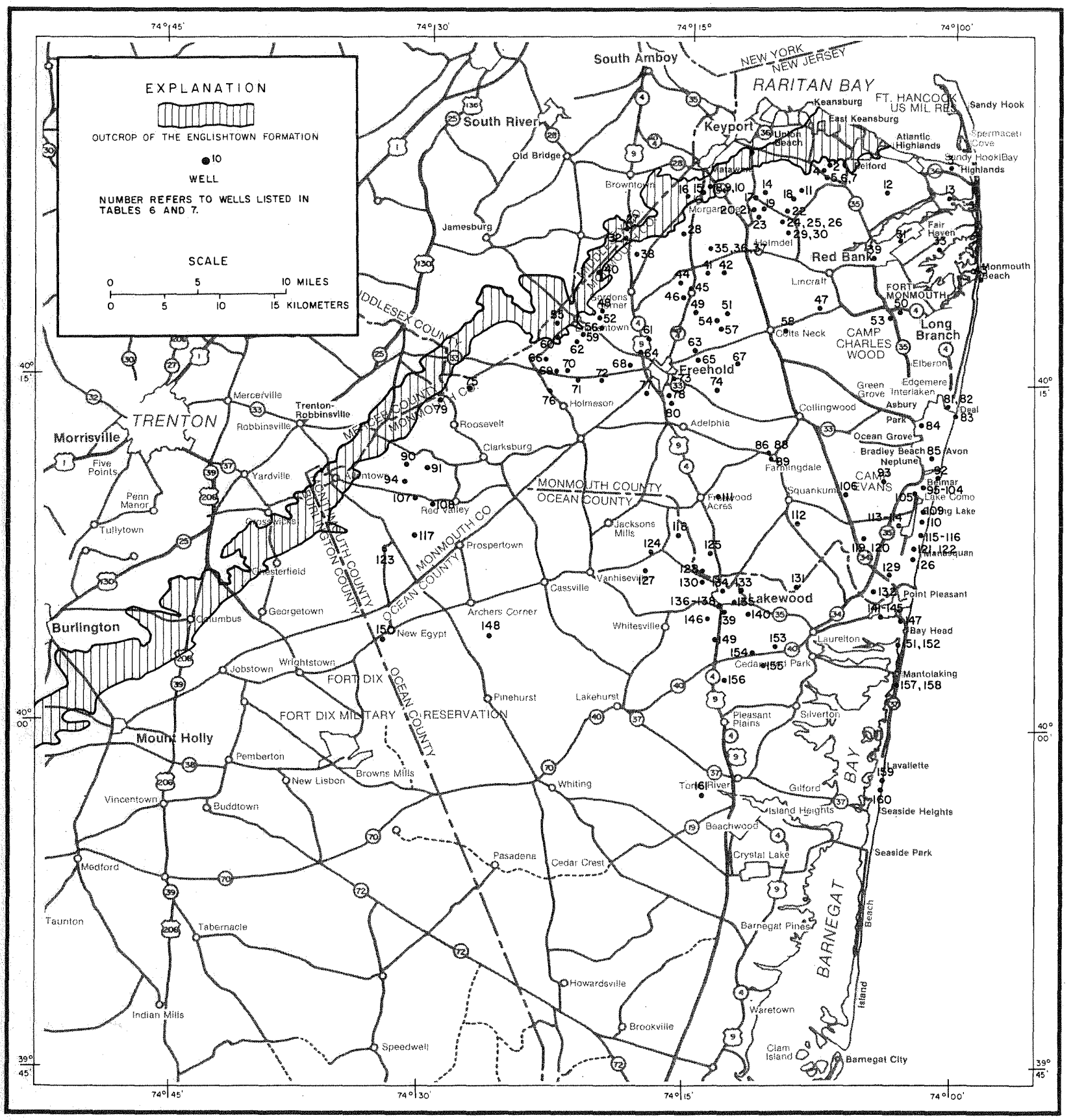

FIGURE 19. --LOCATION OF WELLS DEVELOPED IN THE ENGLISHTOWN AQUIFER IN MONMOUTH AND OCEAN COUNTIES. 


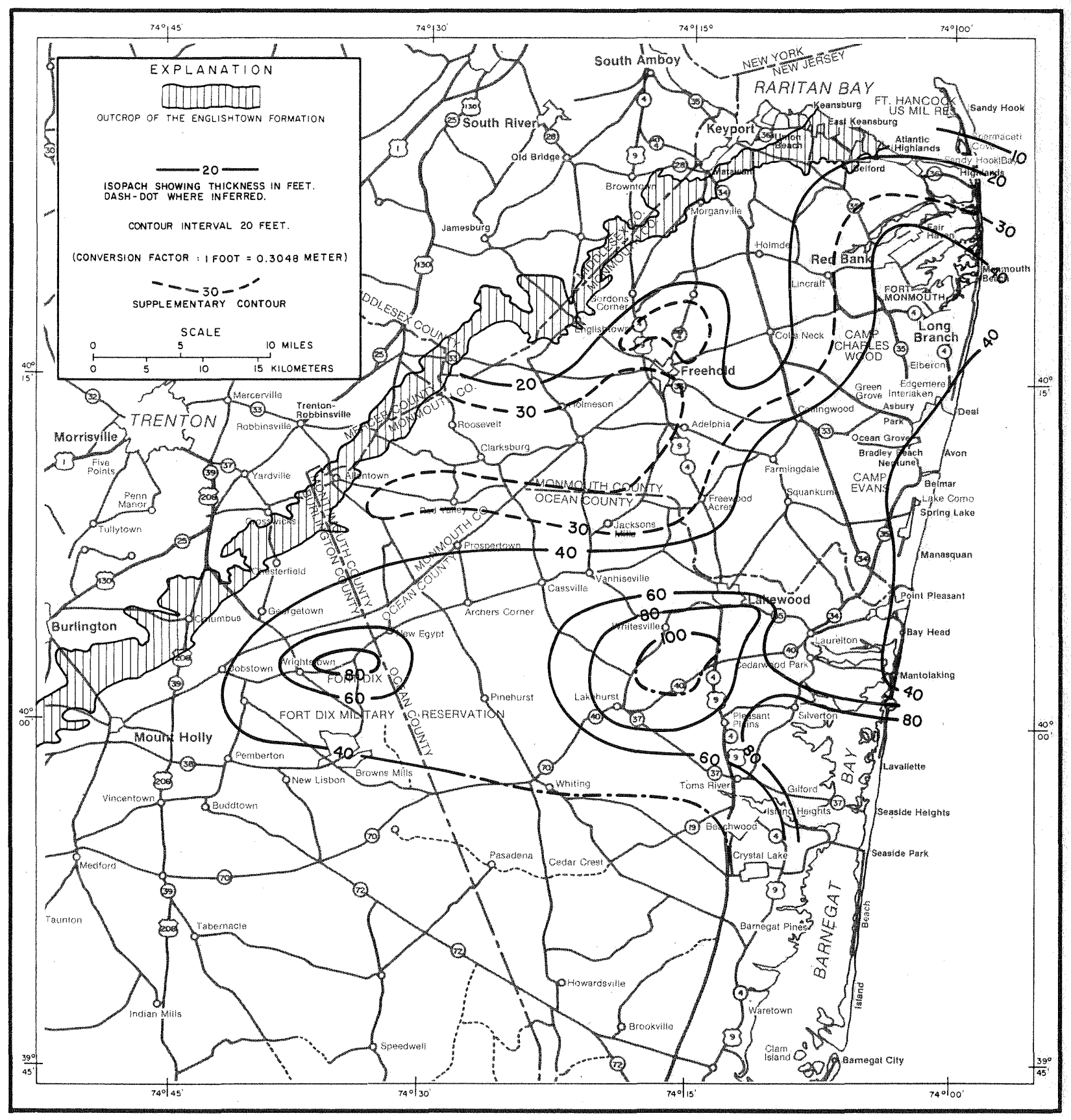

FIGURE 20. --THICKNESS OF THE CONFINING LAYER OVERLYING THE ENGLISHTOWN AQUIFER IN MONMOUTH AND NORTHERN OCEAN AND BURLINGTON COUNTIES, N.J. 
Table 8.--Rate of ground-water withdrawal for public supply from the Englishtown aquifer in Monmouth and Ocean Counties

\begin{tabular}{|c|c|c|c|c|c|c|c|c|c|c|c|c|c|c|}
\hline \multirow{2}{*}{$\begin{array}{l}\text { Map } \\
\text { No. }\end{array}$} & \multirow{2}{*}{\multicolumn{2}{|c|}{$\begin{array}{l}\text { Owner } \\
\text { wel1 number } \\
\text { (see fig. } 18 \\
\text { for locations) }\end{array}$}} & \multirow{2}{*}{\multicolumn{4}{|c|}{$\begin{array}{c}\text { Average } \\
1961 \quad 1962 \\
\end{array}$}} & \multirow{2}{*}{$\begin{array}{l}\text { annual } \\
1963 \\
\end{array}$} & \multicolumn{3}{|c|}{$\begin{array}{c}\text { rate of withdrawal } \\
\text { Year }\end{array}$} & \multicolumn{2}{|l|}{ (Mgal/d) } & \multirow[b]{2}{*}{1969} & \multirow[b]{2}{*}{1970} \\
\hline & & & & & & & & 1964 & 1965 & 1966 & 1967 & 1968 & & \\
\hline 1 & Aldrich Water Co. & 非 4 & -- & -- & -- & -- & - & -- & -- & -- & -- & .04 & .11 & .17 \\
\hline 2 & Allenhurst Water Co. & 非 4 & .13 & .14 & .14 & .14 & .15 & .14 & .14 & .15 & .15 & .17 & .15 & .15 \\
\hline 3 & Asbury Park Water Dept. & 非 4 & .10 & .10 & .10 & .10 & .10 & .10 & .10 & .10 & .10 & .10 & .10 & $.10 *$ \\
\hline 4 & $\begin{array}{l}\text { Atlantic Highlands } \\
\text { Water Dept. }\end{array}$ & 非 2 & .23 & .25 & .27 & .29 & .30 & .20 & .13 & .15 & .13 & .17 & .19 & .19 \\
\hline 5 & Belmar Water Dept. & 10 we11s & .93 & .70 & .68 & .72 & .83 & .83 & .79 & .80 & .84 & .93 & .92 & .91 \\
\hline 6 & Brielle Water Dept. & 非2-3 & .17 & .18 & .15 & .16 & .16 & .16 & .16 & .21 & .20 & .32 & .34 & .32 \\
\hline 7 & Farmingdale Water Dept. & A11 we11s & .04 & .04 & .05 & .05 & .06 & .07 & .09 & .14 & .15 & .09 & .10 & .09 \\
\hline 8 & Freehold Water \& Util. & Point Ivy 非 1 & -- & -- & - & -- & - & -- & -- & -- & -- & -- & .02 & $.04 *$ \\
\hline 9 & Freehold Twp. Water Dept. & Koenig Lane 非 2 & -- & -- & -- & -- & -- & -- & -- & -- & -- & -- & -- & .60 \\
\hline 10 & $\begin{array}{l}\text { Monmouth Consolidated } \\
\text { Water Co. }\end{array}$ & Ocean Grove Sta. 非 20 & .33 & .07 & .60 & .71 & .04 & .05 & .02 & .08 & -- & -- & -- & .01 \\
\hline 11 & Parkway Water Co. & & .02 & .03 & .04 & .07 & .07 & .10 & .08 & .08 & .08 & .09 & .09 & .10 \\
\hline 12 & Red Bank Water Dept. & 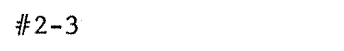 & .64 & .68 & .69 & .67 & .67 & .67 & .65 & .67 & .64 & .77 & .72 & $.62 *$ \\
\hline 13 & Sea Girt Water Dept. & 非4-5 & .19 & .19 & .19 & .20 & .23 & .21 & .21 & .21 & .18 & .19 & .19 & .05 \\
\hline 14 & $\begin{array}{l}\text { Spring Lake Heights } \\
\text { Water Dept. }\end{array}$ & 非2-3 & .20 & .23 & .24 & .23 & .30 & .33 & .28 & .29 & .32 & .42 & .44 & $.53 *$ \\
\hline 15 & Spring Lake Water Dept. & 非1-4 & .48 & .52 & .45 & .47 & .49 & .52 & .45 & .49 & .46 & .53 & .55 & .63 \\
\hline 16 & Wal1 Twp. Water Dept. & Allenwood 非 1 & -- & -- & -- & .11 & .13 & .16 & .17 & .19 & .19 & .18 & .15 & .18 \\
\hline 17 & Wa11 Twp. Water Dept. & Allenwood 非 2 & -- & -- & -- & .10 & .12 & .14 & .16 & .18 & .20 & .20 & .19 & .20 \\
\hline 18 & Wa11 Twp. Water Dept. & West Belmar & -- & -- & -- & .09 & .10 & .11 & .12 & .14 & .13 & .13 & .13 & .15 \\
\hline 19 & Wa11 Twp. Water Dept. & Route 34 we11 & -- & -- & - & -- & -- & -- & -- & -- & -- & .08 & .16 & .18 \\
\hline 20 & Wa11 Twp. Water Dept. & Imperia1 Park 非2 & -- & -- & -- & -- & -- & -- & -- & -- & -- & -- & -- & .06 \\
\hline
\end{tabular}


Table 8.--Rate of ground-water withdrawal for public supply from the Englishtown aquifer in Monmouth and Ocean Counties--Continued

\begin{tabular}{|c|c|c|c|c|c|c|c|c|c|c|c|c|c|c|}
\hline $\begin{array}{l}\text { Map } \\
\text { No. }\end{array}$ & $\begin{array}{c}\text { Water department } \\
\text { or } \\
\text { company }\end{array}$ & $\begin{array}{l}\text { Owner } \\
\text { we11 number } \\
\text { (see fig. } 18 \\
\text { for locations) }\end{array}$ & 1959 & 1960 & 1961 & $\begin{array}{c}\text { Average } \\
1962 \\
\end{array}$ & $\begin{array}{l}\text { annual } \\
1963 \\
\end{array}$ & $\begin{array}{l}\text { rate } \\
\text { Y } \\
1964 \\
\end{array}$ & $\begin{array}{l}\text { with } \\
1965\end{array}$ & $\begin{array}{r}\text { rawal } \\
1966 \\
\end{array}$ & $\begin{array}{c}(\mathrm{Mgal} / \mathrm{d}) \\
1967 \\
\end{array}$ & 1968 & 1969 & 1970 \\
\hline 21 & Jackson Twp. MUA & 非 1 & -- & -- & -- & .09 & .19 & .17 & .17 & .13 & .13 & .11 & .13 & .19 \\
\hline 22 & Jackson Twp. MUA & 非 2 & -- & -- & -- & $-\infty$ & .07 & .21 & .17 & .17 & .15 & .18 & .19 & .28 \\
\hline 23 & Jackson Twp. MUA & 非 3 & -- & - & -- & -- & .01 & .02 & .01 & .11 & .12 & .14 & .17 & .17 \\
\hline 24 & Jackson Twp. MUA & 非 4 & -- & -- & -- & -- & -- & -- & -- & .16 & .16 & .18 & .14 & .11 \\
\hline 25 & Lakewood Water Co. & 非 5 & .75 & .77 & .78 & .75 & .65 & .50 & .22 & .20 & .17 & .10 & .08 & $.10 *$ \\
\hline 26 & Lakewood Water Co. & \#1 6 & -- & - & -- & .12 & .27 & .42 & .56 & .53 & .47 & .47 & .32 & $.33 *$ \\
\hline 27 & Lakewood Water Co. & 非 7 & -- & -- & -- & -- & -- & .24 & .44 & .53 & .45 & .63 & .60 & $.63 *$ \\
\hline 28 & Lakewood Water Co. & 非 8 & -- & -- & -- & -- & -- & -- & - & .06 & .29 & .30 & .32 & $.29 *$ \\
\hline 29 & Lakewood Water Co. & 非 9 & - & -- & - & -- & -- & $\cdots$ & -- & -- & $-\infty$ & .01 & .25 & $.40 *$ \\
\hline 30 & Lava1lette Water Dept. & 非 2-3 & .32 & .31 & .30 & .29 & .30 & .32 & .33 & .25 & .19 & .37 & .40 & $.35 *$ \\
\hline 31 & New Egypt Water Co. & & .10 & .11 & .11 & .10 & .12 & .11 & .12 & .14 & .11 & .11 & .11 & $.12 *$ \\
\hline 32 & Ocean County Water Co. & Bay Head 非5-6 & .38 & .39 & .41 & .44 & .45 & .47 & .47 & .47 & .51 & .63 & .60 & .65 \\
\hline 33 & Ocean County Water Co. & Mantoloking 非 & -- & -- & -- & -- & -- & -- & -- & - & .01 & .00 & .03 & .04 \\
\hline 34 & Point Pleasant Water Dept. & 非 3 & .20 & .09 & .12 & .25 & .26 & .45 & .40 & .21 & .03 & .05 & -- & -- \\
\hline 35 & Point Pleasant Water Dept. & 非 6 & -- & -- & -- & -- & -- & -- & .33 & .72 & .32 & .54 & .47 & .39 \\
\hline 36 & South Lakewood Water Co. & 非1-3（非1 drilled 69) & -- & -- & -- & -- & - & -- & .05 & .06 & .18 & .38 & .56 & .73 \\
\hline
\end{tabular}




\section{Confining Layer Coefficients}

The quantitative analysis of ground-water flow in complex aquifer systems requires reliable values of hydraulic conductivity and specific storage for the confining layers which separate the individual aquifers. These values can be computed from the results of standard soil consolidation tests performed in the laboratory on undisturbed samples (Lambe, 1951; Domenico and Mifflin, 1965). Subsurface core samples were obtained at three sites for laboratory analysis. In all 58 samples were collected and tested; 16 of the samples are from confining beds of the Englishtown aquifer system.

Samples were collected with an 18 -inch $(0.45-\mathrm{m})$ split barrel sampler with three 6 -inch $(0.15-\mathrm{m})$ brass liner inserts. The liner segment containing the sample to be tested was capped at each end, sealed with wax, and stored in a controlled temperature and humidity environment. Consolidation tests were performed by the Hydrologic Laboratory of the U.S. Geological Survey and by the Division of Materials of the New Jersey Department of Transportation. The results of these tests are shown in table 9 .

The upper confining bed of the Englishtown aquifer system was penetrated by the Bradlees Corporation well located in Brick Township in northeastern ocean County. The samples obtained at depths of $605 \mathrm{ft}(184 \mathrm{~m})$ and 625 ft $(190 \mathrm{~m})$ are from the Wenonah Formation; those from $635 \mathrm{ft}(193 \mathrm{~m})$ and $645 \mathrm{ft}(196 \mathrm{~m})$ are from the Marshalltown Formation. The sediments recovered are of the sand-silt-clay and clayey silt types according to the Shepard (1954) classification system (fig. 21B).

Hydraulic conductivity values computed from consolidation test data range from $2.79 \times 10^{-10} \mathrm{ft} / \mathrm{s}$ (feet per second) $\left[8.5 \times 10^{-9} \mathrm{~cm} / \mathrm{s}\right.$ (centimeters per second)] to $6.57 \times 10^{-11} \mathrm{ft} / \mathrm{s}\left(2.0 \times 10^{-9} \mathrm{~cm} / \mathrm{s}\right)$. These values were calculated from data at the load increment nearest the approximate computed overburden pressure of 480 psi (pounds per square inch) $\left[33.7 \mathrm{~kg} / \mathrm{cm}^{2}\right.$ (kilograms per square centimeter)]. Computed values of specific storage range from $1.37 \times 10^{-4} \mathrm{ft}^{-1}\left(4.49 \times 10^{-6} \mathrm{~cm}^{-1}\right)$ to $5.14 \times 10^{-5} \mathrm{ft}^{-1}$ $\left(6.07 \times 10^{-6} \mathrm{~cm}^{-1}\right)$ for the same samples (table 9). The hydraulic diffusivity of the four samples ranges from $1.27 \times 10^{-6} \mathrm{ft}^{2} / \mathrm{s}$ (square feet per second) $\left[1.18 \times 10^{-3} \mathrm{~cm}^{2} / \mathrm{s}\right.$ (square centimeters per second) $]$ to $2.29 \times 10^{-6} \mathrm{ft}^{2} / \mathrm{s}$ $\left(2.13 \times 10^{-3} \mathrm{~cm}^{2} / \mathrm{s}\right)$.

Samples of both confining layers were obtained from a well drilled by the U.S. Army at Fort Dix, New Jersey. One sample was taken of the Marshalltown Formation at a depth of $390 \mathrm{ft}(119 \mathrm{~m})$ and five samples were collected from the Merchantville-Woodbury Formations between depths of $456 \mathrm{ft}(139 \mathrm{~m})$ and $625 \mathrm{ft}(190 \mathrm{~m})$. The Marshalltown sample is a silty sand according to the Shepard classification. A variety of sediment types were recovered from the Merchantville-Woodbury sequence. They ranged from clayey sand to silty clay according to Shepard's classification system (fig. 21A). 


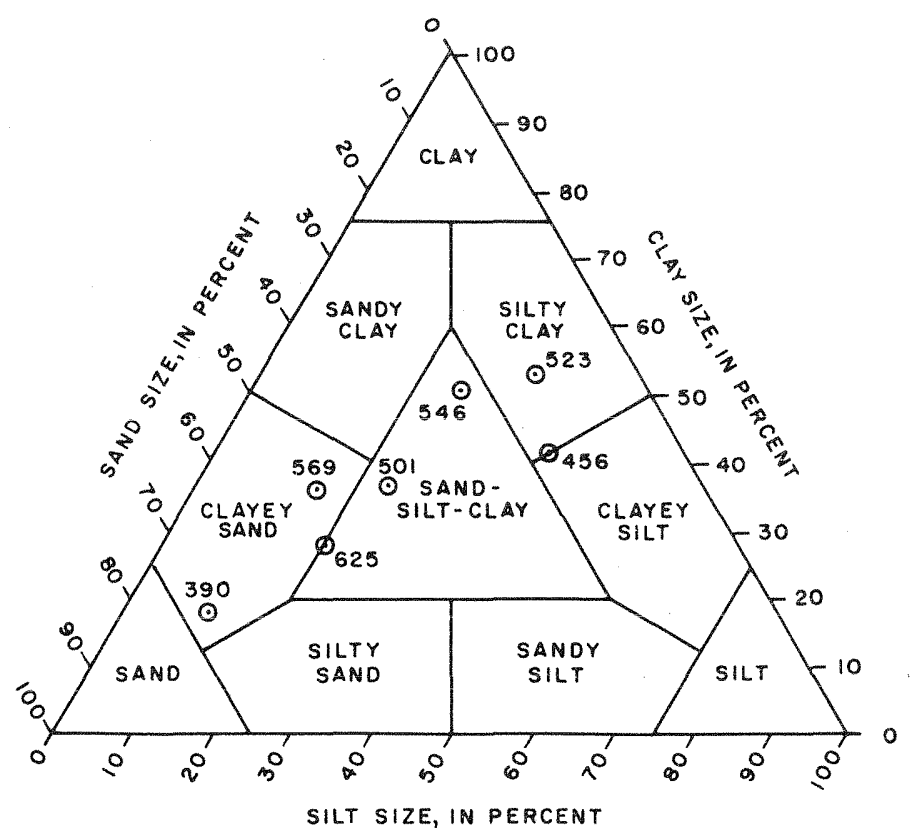

A. FORT DIX TEST WELL 'A'.

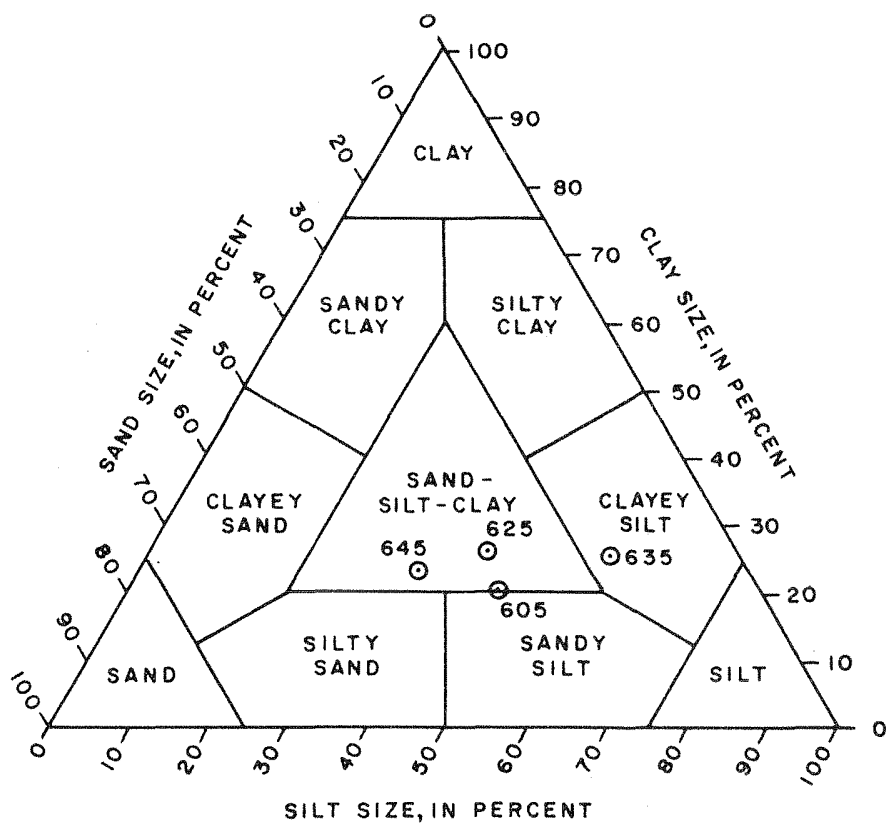

B. BRADLEES CORP. WELL.

FIGURE 21. --SEDIMENT CLASSIFICATION DIAGRAMS FOR SELECTED SAMPLES FROM TEST HOLES PENETRATING THE CONFINING LAYERS OF THE ENGLISHTOWN AQUIFER SYSTEM. NUMBERS INDICATE DEPTH OF SAMPLE. TRIANGULAR PARTICLE-SIZE DIAGRAMS ARE SUBDIVIDED ACCORDING TO THE SYSTEM PROPOSED BY SHEPARD ( 1954 ). 
Table 9.--Consolidation Test Data

U.S. Army, Fort Dix Well 6

New Hanover Twp., Burlington Co., N.J.

\begin{tabular}{|c|c|c|c|c|c|c|c|c|c|c|c|c|c|}
\hline \multirow{2}{*}{$\begin{array}{l}\text { Sample } \\
\text { depth } \\
(\mathrm{ft})\end{array}$} & \multicolumn{2}{|c|}{$\begin{array}{l}\text { Consolidation } \\
\text { load }\end{array}$} & \multicolumn{3}{|c|}{ Consolidation coefficient $-\mathrm{C}_{\mathrm{v}}$} & \multicolumn{2}{|c|}{$\begin{array}{l}\text { Hydraulic } \\
\text { conductivity-K }\end{array}$} & \multicolumn{2}{|c|}{$\begin{array}{l}\text { Specific } \\
\text { storage-Ss }\end{array}$} & \multirow[t]{2}{*}{$\begin{array}{l}\text { Specific } \\
\text { gravity }\end{array}$} & \multirow[t]{2}{*}{$\begin{array}{l}\text { Void } \\
\text { ratio }\end{array}$} & \multirow[t]{2}{*}{$\begin{array}{c}\text { Porosity } \\
\text { (percent) }\end{array}$} & \multirow[t]{2}{*}{$\begin{array}{l}\text { Geol. } \\
\text { Fm。* }\end{array}$} \\
\hline & (psi) & $\left(\mathrm{g} / \mathrm{cm}^{2}\right)$ & $\left(\mathrm{in}^{2} / \mathrm{s}\right)$ & $\left(\mathrm{ft}^{2} / \mathrm{s}\right)$ & $\left(\mathrm{cm}^{2} / \mathrm{s}\right)$ & $(\mathrm{ft} / \mathrm{s})$ & $(\mathrm{cm} / \mathrm{s})$ & $(1 / f t)$ & $(1 / \mathrm{cm})$ & & & & \\
\hline \multirow[t]{2}{*}{116.0} & 111.1 & $7.81 \times 10^{3}$ & $5.74 \times 10^{-5}$ & $3.99 \times 10^{-7}$ & $3.70 \times 10^{-4}$ & $1.80 \times 10^{-10}$ & $5.49 \times 10^{-9}$ & $4.52 \times 10^{-4}$ & $1.48 \times 10^{-5}$ & 2.84 & 0.580 & 36.7 & \\
\hline & 222.2 & $1.56 \times 10^{4}$ & $3.26 \times 10^{-5}$ & $2.26 \times 10^{-7}$ & $2.10 \times 10^{-4}$ & $6.42 \times 10^{-11}$ & $1.96 \times 10^{-9}$ & $2.84 \times 10^{-4}$ & $9.31 \times 10^{-6}$ & 2.84 & 0.473 & 32.1 & \\
\hline \multirow[t]{3}{*}{116.5} & 97.2 & $6.84 \times 10^{3}$ & $3.26 \times 10^{-3}$ & $2.26 \times 10^{-5}$ & $2.10 \times 10^{-2}$ & $7.97 \times 10^{-9}$ & $2.43 \times 10^{-7}$ & $3.52 \times 10^{-4}$ & $1.15 \times 10^{-5}$ & 2.88 & 0.650 & 39.4 & \\
\hline & 125.0 & $8.79 \times 10^{3}$ & $9.54 \times 10^{-4}$ & $6.62 \times 10^{-6}$ & $6.15 \times 10^{-3}$ & $1.83 \times 10^{-10}$ & $5.59 \times 10^{-9}$ & $2.77 \times 10^{-5}$ & $9.08 \times 10^{-7}$ & 2.88 & 0.620 & 38.3 & \\
\hline & 222.2 & $1.56 \times 10^{4}$ & $4.32 \times 10^{-3}$ & $3.00 \times 10^{-5}$ & $2.79 \times 10^{-2}$ & $8.75 \times 10^{-9}$ & $2.67 \times 10^{-7}$ & $2.92 \times 10^{-4}$ & $9.57 \times 10^{-6}$ & 2.88 & 0.522 & 34.3 & \\
\hline \multirow[t]{3}{*}{117.0} & 111.1 & $7.81 \times 10^{3}$ & $1.15 \times 10^{-4}$ & $7.99 \times 10^{-7}$ & $7.42 \times 10^{-4}$ & $2.92 \times 10^{-10}$ & $8.89 \times 10^{-9}$ & $3.65 \times 10^{-4}$ & $1.20 \times 10^{-5}$ & 2.76 & 0.523 & 34.3 & \\
\hline & 222.2 & $1.56 \times 10^{4}$ & $1.79 \times 10^{-5}$ & $1.24 \times 10^{-7}$ & $1.15 \times 10^{-4}$ & $3.09 \times 10^{-11}$ & $9.42 \times 10^{-10}$ & $2.49 \times 10^{-4}$ & $8.16 \times 10^{-6}$ & 2.76 & 0.432 & 30.2 & \\
\hline & 444.4 & $3.12 \times 10^{4}$ & $2.75 \times 10^{-5}$ & $1.91 \times 10^{-7}$ & $1.77 \times 10^{-4}$ & $2.07 \times 10^{-11}$ & $6.30 \times 10^{-10}$ & $1.08 \times 10^{-4}$ & $3.55 \times 10^{-6}$ & 2.76 & 0.357 & 26.3 & \\
\hline \multirow[t]{6}{*}{139.0} & 55.6 & $3.91 \times 10^{3}$ & $2.79 \times 10^{-4}$ & $1.94 \times 10^{-6}$ & $1.80 \times 10^{-3}$ & $3.70 \times 10^{-10}$ & $1.13 \times 10^{-8}$ & $1.91 \times 10^{-4}$ & $6.27 \times 10^{-6}$ & 2.67 & 1.130 & 53.1 & \\
\hline & 55.6 & $3.91 \times 10^{3}$ & $2.12 \times 10^{-4}$ & $1.47 \times 10^{-6}$ & $1.37 \times 10^{-3}$ & $2.89 \times 10^{-10}$ & $8.81 \times 10^{-9}$ & $1.96 \times 10^{-4}$ & $6.44 \times 10^{-6}$ & 2.67 & 1.130 & 53.1 & \\
\hline & 111.1 & $7.81 \times 10^{3}$ & $8.52 \times 10^{-5}$ & $5.92 \times 10^{-7}$ & $5.50 \times 10^{-4}$ & $1.70 \times 10^{-10}$ & $5.18 \times 10^{-9}$ & $2.87 \times 10^{-4}$ & $9.43 \times 10^{-6}$ & 2.67 & 1.054 & 51.3 & \\
\hline & 111.1 & $7.81 \times 10^{3}$ & $5.48 \times 10^{-4}$ & $3.18 \times 10^{-6}$ & $2.95 \times 10^{-3}$ & $9.17 \times 10^{-10}$ & $2.79 \times 10^{-8}$ & $2.88 \times 10^{-4}$ & $9.46 \times 10^{-6}$ & 2.67 & 1.054 & 51.3 & \\
\hline & 166.7 & $1.17 \times 10^{4}$ & $2.60 \times 10^{-5}$ & $1.81 \times 10^{-7}$ & $1.68 \times 10^{-4}$ & $4.37 \times 10^{-11}$ & $1.33 \times 10^{-9}$ & $2.42 \times 10^{-4}$ & $7.93 \times 10^{-6}$ & 2.67 & 0.992 & 49.8 & \\
\hline & 222.2 & $1.56 \times 10^{4}$ & $4.50 \times 10^{-5}$ & $3.12 \times 10^{-7}$ & $2.90 \times 10^{-4}$ & $6.10 \times 10^{-11}$ & $1.86 \times 10^{-9}$ & $1.95 \times 10^{-4}$ & $6.40 \times 10^{-6}$ & 2.67 & 0.943 & 48.5 & \\
\hline \multirow[t]{3}{*}{162.0} & 125.0 & $8.79 \times 10^{3}$ & $3.07 \times 10^{-3}$ & $2.13 \times 10^{-5}$ & $1.98 \times 10^{-2}$ & $.3 .00 \times 10^{-9}$ & $9.14 \times 10^{-8}$ & $1.41 \times 10^{-4}$ & $4.62 \times 10^{-6}$ & 2.44 & 0.469 & 31.9 & \\
\hline & 166.7 & $1.17 \times 10^{4}$ & $7.75 \times 10^{-4}$ & $5.38 \times 10^{-6}$ & $5.00 \times 10^{-3}$ & $5.41 \times 10^{-10}$ & $1.65 \times 10^{-8}$ & $1.00 \times 10^{-4}$ & $3.30 \times 10^{-6}$ & 2.44 & 0.455 & 31.3 & \\
\hline & 222.2 & $1.56 \times 10^{4}$ & $1.94 \times 10^{-4}$ & $1.35 \times 10^{-6}$ & $1.25 \times 10^{-3}$ & $1.10 \times 10^{-10}$ & $3.35 \times 10^{-9}$ & $8.16 \times 10^{-5}$ & $2.68 \times 10^{-6}$ & 2.44 & 0.440 & 30.6 & \\
\hline \multirow[t]{3}{*}{207.0} & 111.1 & $7.81 \times 10^{3}$ & $3.77 \times 10^{-3}$ & $2.62 \times 10^{-5}$ & $2.43 \times 10^{-2}$ & $3.12 \times 10^{-9}$ & $9.50 \times 10^{-8}$ & $1.19 \times 10^{-4}$ & $3.91 \times 10^{-6}$ & 2.92 & 0.508 & 33.7 & \\
\hline & 166.7 & $1.17 \times 10^{4}$ & $1.84 \times 10^{-3}$ & $1.28 \times 10^{-5}$ & $1.19 \times 10^{-2}$ & $9.33 \times 10^{-10}$ & $2.84 \times 10^{-8}$ & $7.30 \times 10^{-5}$ & $2.40 \times 10^{-6}$ & 2.92 & 0.494 & 33.1 & \\
\hline & 222.2 & $1.56 \times 10^{4}$ & $3.76 \times 10^{-4}$ & $2.61 \times 10^{-6}$ & $2.43 \times 10^{-3}$ & $1.22 \times 10^{-10}$ & $3.73 \times 10^{-9}$ & $4.69 \times 10^{-5}$ & $1.54 \times 10^{-6}$ & 2.92 & 0.485 & 32.7 & \\
\hline
\end{tabular}


U.S. Army, Fort Dix Well 6--Continued New Hanover Twp., Burlington Co., N.J.

\begin{tabular}{|c|c|c|c|c|c|c|c|c|c|c|c|c|c|}
\hline \multirow{3}{*}{$\begin{array}{l}\begin{array}{l}\text { Sample } \\
\text { depth } \\
\text { (ft) }\end{array} \\
390.0\end{array}$} & \multicolumn{2}{|c|}{$\begin{array}{c}\text { Consolidation } \\
\text { load } \\
\end{array}$} & \multicolumn{3}{|c|}{ Consolidation coefficient $-\mathrm{C}_{\mathrm{v}}$} & \multicolumn{2}{|c|}{$\begin{array}{c}\text { Hydraulic } \\
\text { conductivity-K }\end{array}$} & \multicolumn{2}{|c|}{$\begin{array}{c}\text { Specific } \\
\text { storage-S }\end{array}$} & \multirow[t]{2}{*}{$\begin{array}{l}\text { Specific } \\
\text { gravity }\end{array}$} & \multirow[t]{2}{*}{$\begin{array}{l}\text { Void } \\
\text { ratio }\end{array}$} & \multirow[t]{2}{*}{$\begin{array}{l}\text { Porosity } \\
\text { (percent) }\end{array}$} & \multirow[t]{2}{*}{$\begin{array}{l}\text { Geol. } \\
\text { Fm。* }\end{array}$} \\
\hline & \multicolumn{2}{|c|}{ (psi) $\quad\left(\mathrm{g} / \mathrm{cm}^{2}\right)$} & $\left(\mathrm{in}^{2} / \mathrm{s}\right)$ & $\left(\mathrm{ft}^{2} / \mathrm{s}\right)$ & $\left(\mathrm{cm}^{2} / \mathrm{s}\right)$ & $(\mathrm{ft} / \mathrm{s})$ & $(\mathrm{cm} / \mathrm{s})$ & $(1 / f t)$ & $(1 / \mathrm{cm})$ & & & & \\
\hline & 222.2 & $1.56 \times 10^{4}$ & $3.92 \times 10^{-3}$ & $2.72 \times 10^{-5}$ & $2.53 \times 10^{-2}$ & $3.00 \times 10^{-9}$ & $9.14 \times 10^{-8}$ & $1.10 \times 10^{-4}$ & $3.62 \times 10^{-6}$ & 2.77 & 0.551 & 35.5 & Kmt \\
\hline & 444.4 & $3.12 \times 10^{4}$ & $2.88 \times 10^{-3}$ & $2.00 \times 10^{-5}$ & $1.86 \times 10^{-2}$ & $1.55 \times 10^{-9}$ & $4.72 \times 10^{-8}$ & $7.75 \times 10^{-5}$ & $2.54 \times 10^{-6}$ & 2.77 & 0.488 & 32.8 & \\
\hline \multirow[t]{3}{*}{456.0} & 222.2 & $1.56 \times 10^{4}$ & $8.44 \times 10^{-4}$ & $5.86 \times 10^{-6}$ & $5.45 \times 10^{-3}$ & $6.87 \times 10^{-10}$ & $2.09 \times 10^{-8}$ & $1.17 \times 10^{-4}$ & $3.84 \times 10^{-6}$ & 2.67 & 0.636 & 38.9 & Kw \\
\hline & 361.1 & $2.54 \times 10^{4}$ & $9.53 \times 10^{-4}$ & $6.62 \times 10^{-6}$ & $6.15 \times 10^{-3}$ & $6.92 \times 10^{-10}$ & $2.11 \times 10^{-8}$ & $1.05 \times 10^{-4}$ & $3.43 \times 10^{-6}$ & 2.67 & 0.583 & 36.8 & \\
\hline & 444.4 & $3.12 \times 10^{4}$ & $8.90 \times 10^{-4}$ & $6.18 \times 10^{-6}$ & $5.74 \times 10^{-3}$ & $4.33 \times 10^{-10}$ & $1.32 \times 10^{-8}$ & $7.01 \times 10^{-5}$ & $2.30 \times 10^{-6}$ & 2.67 & 0.562 & 36.0 & \\
\hline \multirow[t]{3}{*}{523.0} & 111.1 & $7.81 \times 10^{3}$ & $1.15 \times 10^{-4}$ & $7.99 \times 10^{-7}$ & $7.42 \times 10^{-4}$ & $1.44 \times 10^{-10}$ & $4.39 \times 10^{-9}$ & $1.81 \times 10^{-4}$ & $5.92 \times 10^{-6}$ & 2.68 & 0.686 & 40.7 & Kwb \\
\hline & 222.2 & $1.56 \times 10^{4}$ & $5.25 \times 10^{-5}$ & $3.65 \times 10^{-7}$ & $3.39 \times 10^{-4}$ & $8.83 \times 10^{-11}$ & $2.69 \times 10^{-9}$ & $2.42 \times 10^{-4}$ & $7.95 \times 10^{-6}$ & 2.68 & 0.588 & 37.0 & $\mathrm{Kmv}$ \\
\hline & 402.8 & $2.83 \times 10^{4}$ & $4.30 \times 10^{-5}$ & $2.99 \times 10^{-7}$ & $2.77 \times 10^{-4}$ & $1.39 \times 10^{-10}$ & $4.24 \times 10^{-9}$ & $4.66 \times 10^{-4}$ & $1.53 \times 10^{-5}$ & 2.68 & 0.558 & 35.8 & \\
\hline \multirow[t]{4}{*}{546.0} & 111.1 & $7.81 \times 10^{3}$ & $7.39 \times 10^{-5}$ & $5.13 \times 10^{-7}$ & $4.77 \times 10^{-4}$ & $7.62 \times 10^{-11}$ & $2.32 \times 10^{-9}$ & $1.48 \times 10^{-4}$ & $4.87 \times 10^{-6}$ & 2.58 & 0.739 & 42.5 & Kwb \\
\hline & 222.2 & $1.56 \times 10^{4}$ & $9.04 \times 10^{-5}$ & $6.28 \times 10^{-7}$ & $5.83 \times 10^{-4}$ & $6.07 \times 10^{-11}$ & $1.85 \times 10^{-9}$ & $9.68 \times 10^{-5}$ & $3.17 \times 10^{-6}$ & 2.58 & 0.697 & 41.1 & Kmv \\
\hline & 444.4 & $3.12 \times 10^{4}$ & $6.59 \times 10^{-5}$ & $4.58 \times 10^{-7}$ & $4.25 \times 10^{-4}$ & $4.25 \times 10^{-11}$ & $1.30 \times 10^{-9}$ & $9.29 \times 10^{-5}$ & $3.05 \times 10^{-6}$ & 2.58 & 0.620 & 38.3 & \\
\hline & 888.9 & $6.25 \times 10^{4}$ & $2.46 \times 10^{-5}$ & $1.71 \times 10^{-7}$ & $1.59 \times 10^{-4}$ & $3.20 \times 10^{-11}$ & $9.75 \times 10^{-10}$ & $1.87 \times 10^{-4}$ & $6.15 \times 10^{-6}$ & 2.58 & 0.360 & 26.5 & \\
\hline \multirow[t]{4}{*}{569.0} & 111.1 & $7.81 \times 10^{3}$ & $2.48 \times 10^{-4}$ & $1.72 \times 10^{-6}$ & $1.60 \times 10^{-3}$ & $2.70 \times 10^{-10}$ & $8.23 \times 10^{-9}$ & $1.57 \times 10^{-4}$ & $5.14 \times 10^{-6}$ & 2.77 & 0.640 & 39.0 & Kmb \\
\hline & 222.2 & $1.56 \times 10^{4}$ & $1.70 \times 10^{-4}$ & $1.18 \times 10^{-6}$ & $1.10 \times 10^{-3}$ & $1.42 \times 10^{-10}$ & $4.32 \times 10^{-9}$ & $1.20 \times 10^{-4}$ & $3.94 \times 10^{-6}$ & 2.77 & 0.591 & 37.1 & Kmv \\
\hline & 444.4 & $3.12 \times 10^{4}$ & $1.40 \times 10^{-4}$ & $9.72 \times 10^{-7}$ & $9.03 \times 10^{-4}$ & $9.33 \times 10^{-11}$ & $2.84 \times 10^{-9}$ & $9.60 \times 10^{-5}$ & $3.15 \times 10^{-6}$ & 2.77 & 0.517 & 34.1 & \\
\hline & 888.9 & $6.25 \times 10^{4}$ & $1.50 \times 10^{-4}$ & $1.04 \times 10^{-6}$ & $9.68 \times 10^{-4}$ & $8.67 \times 10^{-11}$ & $2.64 \times 10^{-9}$ & $8.32 \times 10^{-5}$ & $2.73 \times 10^{-6}$ & 2.77 & 0.398 & 28.5 & \\
\hline \multirow[t]{4}{*}{625.0} & 111.1 & $7.81 \times 10^{3}$ & $8.79 \times 10^{-4}$ & $6.10 \times 10^{-6}$ & $5.67 \times 10^{-3}$ & $1.22 \times 10^{-9}$ & $3.71 \times 10^{-8}$ & $1.99 \times 10^{-4}$ & $6.54 \times 10^{-6}$ & 2.69 & 0.522 & 34.3 & Kmv \\
\hline & 222.2 & $1.56 \times 10^{4}$ & $8.97 \times 10^{-4}$ & $6.23 \times 10^{-6}$ & $5.79 \times 10^{-3}$ & $6.39 \times 10^{-10}$ & $1.95 \times 10^{-8}$ & $1.03 \times 10^{-4}$ & $3.37 \times 10^{-6}$ & 2.69 & 0.483 & 32.6 & \\
\hline & 444.4 & $3.12 \times 10^{4}$ & $7.61 \times 10^{-4}$ & $5.28 \times 10^{-6}$ & $4.91 \times 10^{-3}$ & $3.46 \times 10^{-10}$ & $1.05 \times 10^{-8}$ & $6.54 \times 10^{-5}$ & $2.15 \times 10^{-6}$ & 2.69 & 0.435 & 30.3 & \\
\hline & 888.9 & $6.25 \times 10^{4}$ & $7.08 \times 10^{-4}$ & $4.92 \times 10^{-6}$ & $4.57 \times 10^{-3}$ & $1.92 \times 10^{-10}$ & $5.84 \times 10^{-9}$ & $3.90 \times 10^{-5}$ & $1.28 \times 10^{-6}$ & 2.69 & 0.380 & 27.5 & \\
\hline
\end{tabular}


Table 9.--Consolidation Test Data--Continued

U.S. Army, Fort Dix Well 6--Continued New Hanover Twp., Burlington Co., N.J.

\begin{tabular}{|c|c|c|c|c|c|c|c|c|c|c|c|c|c|}
\hline \multirow{2}{*}{$\begin{array}{l}\text { Sample } \\
\text { depth } \\
\text { (ft) }\end{array}$} & \multicolumn{2}{|c|}{$\begin{array}{c}\text { Consolidation } \\
\text { 1oad }\end{array}$} & \multicolumn{3}{|c|}{ Consolidation coefficient $-\mathrm{C}_{\mathrm{v}}$} & \multicolumn{2}{|c|}{$\begin{array}{c}\text { Hydraulic } \\
\text { conductivity-K }\end{array}$} & \multicolumn{2}{|c|}{$\begin{array}{c}\text { Specific } \\
\text { storage-Ss }\end{array}$} & \multirow[t]{2}{*}{$\begin{array}{l}\text { Specific } \\
\text { gravity }\end{array}$} & \multirow[t]{2}{*}{$\begin{array}{l}\text { Void } \\
\text { ratio }\end{array}$} & \multirow[t]{2}{*}{$\begin{array}{l}\text { Porosity } \\
\text { (percent) }\end{array}$} & \multirow[t]{2}{*}{$\begin{array}{l}\text { Geol. } \\
\text { Fm。* }\end{array}$} \\
\hline & (psi) & $\left(\mathrm{g} / \mathrm{cm}^{2}\right)$ & $\left(\mathrm{in}^{2} / \mathrm{s}\right)$ & $\left(\mathrm{ft}^{2} / \mathrm{s}\right)$ & $\left(\mathrm{cm}^{2} / \mathrm{s}\right)$ & $(\mathrm{ft} / \mathrm{s})$ & $(\mathrm{cm} / \mathrm{s})$ & $(1 / f t)$ & $(1 / \mathrm{cm})$ & & & & \\
\hline \multirow[t]{5}{*}{660.0} & 55.6 & $3.91 \times 10^{3}$ & $2.51 \times 10^{-4}$ & $1.74 \times 10^{-6}$ & $1.62 \times 10^{-3}$ & $3.38 \times 10^{-10}$ & $1.03 \times 10^{-8}$ & $1.94 \times 10^{-4}$ & $6.37 \times 10^{-6}$ & 2.67 & 0.356 & 26.3 & \\
\hline & 111.1 & $7.81 \times 10^{3}$ & $4.42 \times 10^{-4}$ & $3.07 \times 10^{-6}$ & $2.85 \times 10^{-3}$ & $6.78 \times 10^{-10}$ & $2.07 \times 10^{-8}$ & $2.21 \times 10^{-4}$ & $7.25 \times 10^{-6}$ & 2.67 & 0.312 & 23.8 & \\
\hline & 222.2 & $1.56 \times 10^{4}$ & $3.55 \times 10^{-4}$ & $2.47 \times 10^{-6}$ & $2.29 \times 10^{-3}$ & $2.79 \times 10^{-10}$ & $8.51 \times 10^{-9}$ & $1.13 \times 10^{-4}$ & $3.72 \times 10^{-6}$ & 2.67 & 0.274 & 21.5 & \\
\hline & 444.4 & $3.12 \times 10^{4}$ & $5.42 \times 10^{-4}$ & $3.76 \times 10^{-6}$ & $3.50 \times 10^{-3}$ & $2.83 \times 10^{-10}$ & $8.64 \times 10^{-9}$ & $7.53 \times 10^{-5}$ & $2.47 \times 10^{-6}$ & 2.67 & 0.159 & 13.7 & \\
\hline & 888.9 & $6.25 \times 10^{4}$ & $8.60 \times 10^{-4}$ & $5.97 \times 10^{-6}$ & $5.55 \times 10^{-3}$ & $3.09 \times 10^{-10}$ & $9.42 \times 10^{-9}$ & $5.18 \times 10^{-5}$ & $1.70 \times 10^{-6}$ & 2.67 & 0.159 & 13.7 & \\
\hline \multirow[t]{4}{*}{772.0} & 111.1 & $7.81 \times 10^{3}$ & $4.96 \times 10^{-4}$ & $3.44 \times 10^{-6}$ & $3.20 \times 10^{-3}$ & $6.97 \times 10^{-10}$ & $2.13 \times 10^{-8}$ & $2.02 \times 10^{-4}$ & $6.64 \times 10^{-6}$ & 2.74 & 0.453 & 31.2 & \\
\hline & 222.2 & $1.56 \times 10^{4}$ & $5.33 \times 10^{-4}$ & $3.70 \times 10^{-6}$ & $3.44 \times 10^{-3}$ & $4.09 \times 10^{-10}$ & $1.25 \times 10^{-8}$ & $1.11 \times 10^{-4}$ & $3.63 \times 10^{-6}$ & 2.74 & 0.413 & 29.2 & \\
\hline & 444.4 & $3.12 \times 10^{4}$ & $5.64 \times 10^{-4}$ & $3.92 \times 10^{-6}$ & $3.64 \times 10^{-3}$ & $2.58 \times 10^{-10}$ & $7.87 \times 10^{-9}$ & $6.60 \times 10^{-5}$ & $2.16 \times 10^{-6}$ & 2.74 & 0.367 & 26.8 & \\
\hline & 888.9 & $6.25 \times 10^{4}$ & $4.99 \times 10^{-4}$ & $3.47 \times 10^{-6}$ & $3.22 \times 10^{-3}$ & $1.42 \times 10^{-10}$ & $4.32 \times 10^{-9}$ & $4.09 \times 10^{-5}$ & $1.34 \times 10^{-6}$ & 2.74 & 0.312 & 23.8 & \\
\hline \multirow[t]{4}{*}{795.0} & 111.1 & $7.81 \times 10^{3}$ & $5.25 \times 10^{-4}$ & $3.65 \times 10^{-6}$ & $3.39 \times 10^{-3}$ & $8.05 \times 10^{-10}$ & $2.45 \times 10^{-8}$ & $2.21 \times 10^{-4}$ & $7.24 \times 10^{-6}$ & 2.58 & 0.413 & 29.2 & \\
\hline & 222.2 & $1.56 \times 10^{4}$ & $5.76 \times 10^{-4}$ & $4.00 \times 10^{-6}$ & $3.72 \times 10^{-3}$ & $5.17 \times 10^{-10}$ & $1.57 \times 10^{-8}$ & $1.29 \times 10^{-4}$ & $4.24 \times 10^{-6}$ & 2.58 & 0.366 & 26.8 & \\
\hline & 444.4 & $3.12 \times 10^{4}$ & $7.30 \times 10^{-4}$ & $5.07 \times 10^{-6}$ & $4.71 \times 10^{-3}$ & $4.63 \times 10^{-10}$ & $1.41 \times 10^{-8}$ & $9.14 \times 10^{-5}$ & $3.00 \times 10^{-6}$ & 2.58 & 0.305 & 23.4 & \\
\hline & 888.9 & $6.25 \times 10^{4}$ & $1.00 \times 10^{-3}$ & $6.94 \times 10^{-6}$ & $6.45 \times 10^{-3}$ & $3.28 \times 10^{-10}$ & $1.00 \times 10^{-8}$ & $4.73 \times 10^{-5}$ & $1.55 \times 10^{-6}$ & 2.58 & 0.245 & 19.7 & \\
\hline \multirow[t]{3}{*}{844.0} & 111.1 & $7.81 \times 10^{3}$ & $1.27 \times 10^{-3}$ & $8.82 \times 10^{-6}$ & $8.19 \times 10^{-3}$ & $1.44 \times 10^{-9}$ & $4.39 \times 10^{-8}$ & $1.63 \times 10^{-4}$ & $5.36 \times 10^{-6}$ & 2.72 & 0.389 & 28.0 & \\
\hline & 222.2 & $1.56 \times 10^{4}$ & $2.18 \times 10^{-3}$ & $1.51 \times 10^{-5}$ & $1.41 \times 10^{-2}$ & $6.41 \times 10^{-10}$ & $1.95 \times 10^{-8}$ & $4.23 \times 10^{-5}$ & $1.39 \times 10^{-6}$ & 2.72 & 0.374 & 27.2 & \\
\hline & 444.4 & $3.12 \times 10^{4}$ & $2.13 \times 10^{-3}$ & $1.48 \times 10^{-5}$ & $1.37 \times 10^{-2}$ & $4.41 \times 10^{-10}$ & $1.34 \times 10^{-8}$ & $2.98 \times 10^{-5}$ & $9.78 \times 10^{-7}$ & 2.72 & 0.352 & 26.0 & \\
\hline 866.0 & 444.4 & $3.12 \times 10^{4}$ & $1.51 \times 10^{-3}$ & $1.05 \times 10^{-5}$ & $9.74 \times 10^{-3}$ & $5.67 \times 10^{-10}$ & $1.73 \times 10^{-8}$ & $5.41 \times 10^{-5}$ & $1.78 \times 10^{-6}$ & 2.74 & 0.311 & 23.7 & \\
\hline \multirow[t]{4}{*}{889.0} & 111.1 & $7.81 \times 10^{3}$ & $1.73 \times 10^{-3}$ & $1.20 \times 10^{-5}$ & $1.12 \times 10^{-2}$ & $4.14 \times 10^{-9}$ & $1.26 \times 10^{-7}$ & $3.45 \times 10^{-4}$ & $1.13 \times 10^{-5}$ & 2.61 & 0.284 & 22.1 & \\
\hline & 222.2 & $1.56 \times 10^{4}$ & $6.72 \times 10^{-3}$ & $4.67 \times 10^{-5}$ & $4.34 \times 10^{-2}$ & $3.92 \times 10^{-9}$ & $1.20 \times 10^{-7}$ & $8.41 \times 10^{-5}$ & $2.76 \times 10^{-6}$ & 2.61 & 0.257 & 20.4 & \\
\hline & 444.4 & $3.12 \times 10^{4}$ & $7.61 \times 10^{-3}$ & $5.28 \times 10^{-5}$ & $4.91 \times 10^{-2}$ & $2.61 \times 10^{-9}$ & $7.95 \times 10^{-8}$ & $4.94 \times 10^{-5}$ & $1.62 \times 10^{-6}$ & 2.61 & 0.226 & 18.4 & \\
\hline & 611.1 & $4.30 \times 10^{4}$ & $2.74 \times 10^{-4}$ & $1.90 \times 10^{-6}$ & $1.77 \times 10^{-3}$ & $4.89 \times 10^{-11}$ & $1.49 \times 10^{-9}$ & $2.57 \times 10^{-5}$ & $8.43 \times 10^{-7}$ & 2.61 & 0.214 & 17.6 & \\
\hline
\end{tabular}


Table 9.---Consolidation Test Data--Continued

U.S. Arny, Fort Dix Well 6--Continued

New Hanover Twp., Burlington $C_{0}$, , N.J.

\begin{tabular}{|c|c|c|c|c|c|c|c|c|c|c|c|c|c|}
\hline \multirow{2}{*}{$\begin{array}{l}\text { Sample } \\
\text { depth } \\
(f t)\end{array}$} & \multicolumn{2}{|c|}{$\begin{array}{c}\text { Consolidation } \\
\text { load }\end{array}$} & \multicolumn{3}{|c|}{ Consolidation coefficient $-\mathrm{C}_{\mathrm{v}}$} & \multicolumn{2}{|c|}{$\begin{array}{c}\text { Hydraulic } \\
\text { conductivity-K }\end{array}$} & \multicolumn{2}{|c|}{$\begin{array}{c}\text { Specific } \\
\text { storage-s }\end{array}$} & \multirow[t]{2}{*}{$\begin{array}{l}\text { Specific } \\
\text { gravity }\end{array}$} & \multirow[t]{2}{*}{$\begin{array}{l}\text { Void } \\
\text { ratio }\end{array}$} & \multirow[t]{2}{*}{$\begin{array}{l}\text { Porosity } \\
\text { (percent) }\end{array}$} & \multirow[t]{2}{*}{$\begin{array}{l}\text { Geol. } \\
\text { Fm.* }\end{array}$} \\
\hline & $(p s i)$ & $\left(\mathrm{g} / \mathrm{cm}^{2}\right)$ & $\left(\mathrm{in}^{2} / \mathrm{s}\right)$ & $\left(f t^{2} / s\right)$ & $\left(\mathrm{cm}^{2} / \mathrm{s}\right)$ & $(f t / s)$ & $(\mathrm{cm} / \mathrm{s})$ & $(1 / f t)$ & $(1 / \mathrm{cm})$ & & & & \\
\hline \multirow[t]{2}{*}{889.0} & 694.4 & $4.88 \times 10^{4}$ & $1.45 \times 10^{-3}$ & $1.01 \times 10^{-5}$ & $9.35 \times 10^{-3}$ & $2.62 \times 10^{-10}$ & $7.98 \times 10^{-9}$ & $2.60 \times 10^{-5}$ & $8.53 \times 10^{-7}$ & 2.61 & 0.208 & 17.2 & \\
\hline & 833.3 & $5.86 \times 10^{4}$ & $1.46 \times 10^{-3}$ & $1.01 \times 10^{-5}$ & $9.42 \times 10^{-3}$ & $1.05 \times 10^{-10}$ & $3.20 \times 10^{-9}$ & $1.04 \times 10^{-5}$ & $3.40 \times 10^{-7}$ & 2.61 & 0.204 & 16.9 & \\
\hline \multirow[t]{4}{*}{935.0} & 111.1 & $7.81 \times 10^{3}$ & $2.38 \times 10^{-4}$ & $1.65 \times 10^{-6}$ & $1.54 \times 10^{-3}$ & $2.78 \times 10^{-10}$ & $8.48 \times 10^{-9}$ & $1.68 \times 10^{-4}$ & $5.53 \times 10^{-6}$ & 2.66 & 0.299 & 23.0 & \\
\hline & 222.2 & $1.56 \times 10^{4}$ & $3.92 \times 10^{-4}$ & $2.72 \times 10^{-6}$ & $2.53 \times 10^{-3}$ & $7.73 \times 10^{-10}$ & $2.36 \times 10^{-8}$ & $2.84 \times 10^{-4}$ & $9.32 \times 10^{-6}$ & 2.66 & 0.211 & 17.4 & \\
\hline & 444.4 & $3.12 \times 10^{4}$ & $5.84 \times 10^{-4}$ & $4.06 \times 10^{-6}$ & $3.77 \times 10^{-3}$ & $3.34 \times 10^{-10}$ & $1.02 \times 10^{-8}$ & $8.24 \times 10^{-5}$ & $2.70 \times 10^{-6}$ & 2.66 & 0.162 & 13.9 & \\
\hline & 888.9 & $6.25 \times 10^{4}$ & $6.44 \times 10^{-4}$ & $4.47 \times 10^{-6}$ & $4.15 \times 10^{-3}$ & $1.88 \times 10^{-10}$ & $5.74 \times 10^{-9}$ & $4.21 \times 10^{-5}$ & $1.38 \times 10^{-6}$ & 2.66 & 0.114 & 10.2 & \\
\hline \multirow[t]{3}{*}{956.0} & 222.2 & $1.56 \times 10^{4}$ & $4.17 \times 10^{-4}$ & $2.90 \times 10^{-6}$ & $2.69 \times 10^{-3}$ & $3.54 \times 10^{-10}$ & $1.08 \times 10^{-8}$ & $1.22 \times 10^{-4}$ & $4.01 \times 10^{-6}$ & 2.73 & 0.281 & 21.9 & \\
\hline & 444.4 & $3.12 \times 10^{4}$ & $3.23 \times 10^{-4}$ & $2.24 \times 10^{-6}$ & $2.08 \times 10^{-3}$ & $1.90 \times 10^{-10}$ & $5.79 \times 10^{-9}$ & $8.47 \times 10^{-5}$ & $2.78 \times 10^{-6}$ & 2.73 & 0.228 & 18.6 & \\
\hline & 888.9 & $6.25 \times 10^{4}$ & $3.94 \times 10^{-4}$ & $2.74 \times 10^{-6}$ & $2.54 \times 10^{-3}$ & $8.75 \times 10^{-11}$ & $2.67 \times 10^{-9}$ & $3.20 \times 10^{-5}$ & $1.05 \times 10^{-6}$ & 2.73 & 0.172 & 14.7 & \\
\hline \multirow[t]{3}{*}{979.0} & 222.2 & $1.56 \times 10^{4}$ & $4.63 \times 10^{-4}$ & $3.22 \times 10^{-6}$ & $2.99 \times 10^{-3}$ & $2.18 \times 10^{-10}$ & $6.65 \times 10^{-9}$ & $6.79 \times 10^{-5}$ & $2.23 \times 10^{-6}$ & 2.72 & 0.323 & 24.4 & \\
\hline & 444.4 & $3.12 \times 10^{4}$ & $8.04 \times 10^{-4}$ & $5.58 \times 10^{-6}$ & $5.19 \times 10^{-3}$ & $2.28 \times 10^{-10}$ & $6.96 \times 10^{-9}$ & $4.09 \times 10^{-5}$ & $1.34 \times 10^{-6}$ & 2.72 & 0.296 & 22.8 & \\
\hline & 888.9 & $6.25 \times 10^{4}$ & $5.90 \times 10^{-4}$ & $4.10 \times 10^{-6}$ & $3.81 \times 10^{-3}$ & $1.02 \times 10^{-10}$ & $3.10 \times 10^{-9}$ & $2.48 \times 10^{-5}$ & $8.14 \times 10^{-7}$ & 2.72 & 0.264 & 20.9 & \\
\hline \multirow[t]{3}{*}{1000.0} & 666.7 & $4.69 \times 10^{4}$ & $3.51 \times 10^{-4}$ & $2.44 \times 10^{-6}$ & $2.26 \times 10^{-3}$ & $7.22 \times 10^{-11}$ & $2.20 \times 10^{-9}$ & $2.96 \times 10^{-5}$ & $9.71 \times 10^{-7}$ & 2.69 & 0.188 & 15.8 & \\
\hline & 888.9 & $6.25 \times 10^{4}$ & $2.51 \times 10^{-4}$ & $1.74 \times 10^{-6}$ & $1.62 \times 10^{-3}$ & $3.48 \times 10^{-11}$ & $1.06 \times 10^{-9}$ & $2.00 \times 10^{-5}$ & $6.56 \times 10^{-7}$ & 2.69 & 0.176 & 15.0 & \\
\hline & & & & & Brick Towr & $\begin{array}{l}\text { dless Corp. W } \\
\text { hip, Ocean Co }\end{array}$ & N T & & & & & & \\
\hline \multirow[t]{2}{*}{225.0} & 222.2 & $1.56 \times 10^{4}$ & $3.42 \times 10^{-3}$ & $2.37 \times 10^{-5}$ & $2.21 \times 10^{-2}$ & $2.63 \times 10^{-10}$ & $8.03 \times 10^{-9}$ & $1.11 \times 10^{-5}$ & $3.64 \times 10^{-7}$ & 2.67 & -- & -- & \\
\hline & 81.0 & $5.69 \times 10^{3}$ & $4.17 \times 10^{-5}$ & $2.90 \times 10^{-7}$ & $2.69 \times 10^{-4}$ & $2.66 \times 10^{-10}$ & $8.10 \times 10^{-9}$ & $9.18 \times 10^{-4}$ & $3.01 \times 10^{-5}$ & -- & 0.930 & 48.2 & \\
\hline \multirow[t]{2}{*}{255.0} & 222.2 & $1.56 \times 10^{4}$ & $1.60 \times 10^{-3}$ & $1.11 \times 10^{-5}$ & $1.03 \times 10^{-2}$ & $1.68 \times 10^{-7}$ & $5.13 \times 10^{-6}$ & $1.51 \times 10^{-2}$ & $4.97 \times 10^{-4}$ & 2.60 & -- & - & \\
\hline & 92.2 & $6.48 \times 10^{3}$ & $3.43 \times 10^{-3}$ & $2.38 \times 10^{-5}$ & $2.21 \times 10^{-2}$ & $1.70 \times 10^{-8}$ & $5.18 \times 10^{-7}$ & $7.14 \times 10^{-4}$ & $2.34 \times 10^{-5}$ & -- & 0.725 & 42.0 & \\
\hline
\end{tabular}


Table 9.--Gonselidated Test Data--Continued

Bradlees Corp Wel1--Continued

Brick Township, Ocean County, N.J.

\begin{tabular}{|c|c|c|c|c|c|c|c|c|c|c|c|c|c|}
\hline \multirow{2}{*}{$\begin{array}{l}\text { Sample } \\
\text { depth } \\
\text { (ft) }\end{array}$} & \multicolumn{2}{|c|}{$\begin{array}{c}\text { Consolidation } \\
\text { load }\end{array}$} & \multicolumn{3}{|c|}{ Consolidation coefficient $-\mathrm{C}_{\mathrm{v}}$} & \multicolumn{2}{|c|}{$\begin{array}{c}\text { Hydraulic } \\
\text { conductivity-K }\end{array}$} & \multicolumn{2}{|c|}{$\begin{array}{c}\text { Specific } \\
\text { storage-Ss }\end{array}$} & \multirow[t]{2}{*}{$\begin{array}{l}\text { Specific } \\
\text { gravity }\end{array}$} & \multirow[t]{2}{*}{$\begin{array}{l}\text { Void } \\
\text { ratic }\end{array}$} & \multirow[t]{2}{*}{$\begin{array}{l}\text { Porosity } \\
\text { (percent) }\end{array}$} & \multirow[t]{2}{*}{$\begin{array}{l}\text { Geoi. } \\
\mathrm{Fm}_{0} *\end{array}$} \\
\hline & $(p s i)$ & $\left(\mathrm{g} / \mathrm{cm}^{2}\right)$ & $\left(\mathrm{in}^{2} / \mathrm{s}\right)$ & $\left(f t^{2} / s\right)$ & $\left(\mathrm{cm}^{2} / \mathrm{s}\right)$ & $(f t / s)$ & $(\mathrm{cm} / \mathrm{s})$ & $(1 / f t)$ & $(1 / \mathrm{cm})$ & & & & \\
\hline \multirow[t]{2}{*}{270.0} & 222.2 & $1.56 \times 10^{4}$ & $6.51 \times 10^{-3}$ & $4.52 \times 10^{-5}$ & $4.20 \times 10^{-2}$ & $1.29 \times 10^{-10}$ & $3.94 \times 10^{-9}$ & $2.86 \times 10^{-6}$ & $9.37 \times 10^{-8}$ & 2.70 & - & -- & \\
\hline & 98.2 & $6.90 \times 10^{3}$ & $9.25 \times 10^{-5}$ & $6.42 \times 10^{-7}$ & $5.97 \times 10^{-4}$ & $6.89 \times 10^{-10}$ & $2.10 \times 10^{-8}$ & $1.07 \times 10^{-3}$ & $3.52 \times 10^{-5}$ & -- & 0.890 & 47.1 & \\
\hline 300.0 & 222.2 & $1.56 \times 10^{4}$ & $6.95 \times 10^{-3}$ & $4.83 \times 10^{-5}$ & $4.48 \times 10^{-2}$ & $5.83 \times 10^{-9}$ & $1.78 \times 10^{-7}$ & $1.21 \times 10^{-4}$ & $3.97 \times 10^{-6}$ & 2.54 & - & $\cdots$ & \\
\hline 322.0 & 222.2 & $1.56 \times 10^{4}$ & $1.70 \times 10^{-3}$ & $1.18 \times 10^{-5}$ & $1.10 \times 10^{-2}$ & $7.52 \times 10^{-10}$ & $2.29 \times 10^{-8}$ & $6.37 \times 10^{-5}$ & $2.09 \times 10^{-6}$ & 2.56 & -- & - & \\
\hline 352.0 & 222.2 & $1.56 \times 10^{4}$ & $1.86 \times 10^{-3}$ & $1.29 \times 10^{-5}$ & $1.20 \times 10^{-2}$ & $2.32 \times 10^{-10}$ & $7.06 \times 10^{-9}$ & $1.79 \times 10^{-5}$ & $5.88 \times 10^{-7}$ & 2.77 & -- & -- & \\
\hline 370.0 & 222.2 & $1.56 \times 10^{4}$ & $4.27 \times 10^{-3}$ & $2.97 \times 10^{-5}$ & $2.75 \times 10^{-2}$ & $6.11 \times 10^{-11}$ & $1.86 \times 10^{-9}$ & $2.06 \times 10^{-6}$ & $6.76 \times 10^{-8}$ & 2.61 & -- & -- & \\
\hline 400.0 & 222.2 & $1.56 \times 10^{4}$ & $8.60 \times 10^{-4}$ & $5.97 \times 10^{-6}$ & $5.55 \times 10^{-3}$ & $7.96 \times 10^{-9}$ & $2.43 \times 10^{-7}$ & $1.33 \times 10^{-3}$ & $4.37 \times 10^{-5}$ & 2.64 & -- & - & \\
\hline 432.0 & 222.2 & $1.56 \times 10^{4}$ & $1.71 \times 10^{-4}$ & $1.19 \times 10^{-6}$ & $1.10 \times 10^{-3}$ & - & -- & - & - & 2.68 & -- & - & \\
\hline \multirow[t]{3}{*}{489.0} & 115.0 & $8.09 \times 10^{3}$ & $5.49 \times 10^{-5}$ & $3.81 \times 10^{-7}$ & $3.54 \times 10^{-4}$ & $2.13 \times 10^{-10}$ & $6.50 \times 10^{-9}$ & $5.60 \times 10^{-4}$ & $1.84 \times 10^{-5}$ & - & 1.270 & 55.9 & \\
\hline & 230.0 & $1.62 \times 10^{4}$ & $2.37 \times 10^{-5}$ & $1.65 \times 10^{-7}$ & $1.53 \times 10^{-4}$ & $4.92 \times 10^{-11}$ & $1.50 \times 10^{-9}$ & $2.99 \times 10^{-4}$ & $9.80 \times 10^{-6}$ & - & 1.180 & 54.1 & \\
\hline & 460.0 & $3.23 \times 10^{4}$ & $1.45 \times 10^{-5}$ & $1.01 \times 10^{-7}$ & $9.35 \times 10^{-5}$ & $1.54 \times 10^{-11}$ & $4.70 \times 10^{-10}$ & $1.53 \times 10^{-4}$ & $5.02 \times 10^{-6}$ & - & 1.070 & 51.7 & \\
\hline \multirow[t]{3}{*}{550.0} & 126.0 & $8.86 \times 10^{3}$ & $3.84 \times 10^{-3}$ & $2.67 \times 10^{-5}$ & $2.48 \times 10^{-2}$ & $5.25 \times 10^{-9}$ & $1.60 \times 10^{-7}$ & $1.97 \times 10^{-4}$ & $6.46 \times 10^{-6}$ & -- & 1.380 & 58.0 & \\
\hline & 252.0 & $1.77 \times 10^{4}$ & $2.82 \times 10^{-3}$ & $1.96 \times 10^{-5}$ & $1.82 \times 10^{-2}$ & $1.90 \times 10^{-9}$ & $5.79 \times 10^{-8}$ & $9.70 \times 10^{-5}$ & $3.18 \times 10^{-6}$ & - & 1.330 & 57.1 & \\
\hline & 504.0 & $3.54 \times 10^{4}$ & $1.36 \times 10^{-3}$ & $9.44 \times 10^{-6}$ & $8.77 \times 10^{-3}$ & $8.83 \times 10^{-10}$ & $2.69 \times 10^{-8}$ & $9.35 \times 10^{-5}$ & $3.07 \times 10^{-6}$ & - & 1.290 & 56.3 & \\
\hline \multirow[t]{3}{*}{605.0} & 138.0 & $9.70 \times 10^{3}$ & $8.39 \times 10^{-4}$ & $5.83 \times 10^{-6}$ & $5.41 \times 10^{-3}$ & $1.97 \times 10^{-9}$ & $5.99 \times 10^{-8}$ & $3.38 \times 10^{-4}$ & $1.11 \times 10^{-5}$ & -- & 0.920 & 47.9 & Kw \\
\hline & 276.0 & $1.94 \times 10^{4}$ & $5.36 \times 10^{-4}$ & $3.72 \times 10^{-6}$ & $3.46 \times 10^{-3}$ & $6.88 \times 10^{-10}$ & $2.10 \times 10^{-8}$ & $1.85 \times 10^{-4}$ & $6.07 \times 10^{-6}$ & -- & 0.860 & 46.2 & \\
\hline & 551.0 & $3.87 \times 10^{4}$ & $3.30 \times 10^{-4}$ & $2.29 \times 10^{-6}$ & $2.13 \times 10^{-3}$ & $2.10 \times 10^{-10}$ & $6.40 \times 10^{-9}$ & $9.16 \times 10^{-5}$ & $3.01 \times 10^{-6}$ & -- & 0.780 & 43.8 & \\
\hline \multirow[t]{3}{*}{625.0} & 141.0 & $9.91 \times 10^{3}$ & $5.40 \times 10^{-4}$ & $3.75 \times 10^{-6}$ & $3.48 \times 10^{-3}$ & $6.88 \times 10^{-10}$ & $2.10 \times 10^{-8}$ & $1.84 \times 10^{-4}$ & $6.02 \times 10^{-6}$ & -- & 1.130 & 53.1 & Kw \\
\hline & 282.0 & $1.98 \times 10^{4}$ & $6.00 \times 10^{-4}$ & $4.17 \times 10^{-6}$ & $3.87 \times 10^{-3}$ & $4.27 \times 10^{-10}$ & $1.30 \times 10^{-8}$ & $1.02 \times 10^{-4}$ & $3.36 \times 10^{-6}$ & -- & 1.100 & 52.4 & \\
\hline & 564.0 & $3.97 \times 10^{4}$ & $1.84 \times 10^{-4}$ & $1.28 \times 10^{-6}$ & $1.19 \times 10^{-3}$ & $6.57 \times 10^{-11}$ & $2.00 \times 10^{-9}$ & $5.14 \times 10^{-5}$ & $1.69 \times 10^{-6}$ & -- & 1.020 & 50.5 & \\
\hline
\end{tabular}


Table 9.--Consolidation Test Data--Continued

Bradlees Corp. Wel1--Continued

Brick Township, Ocean County, N.J.

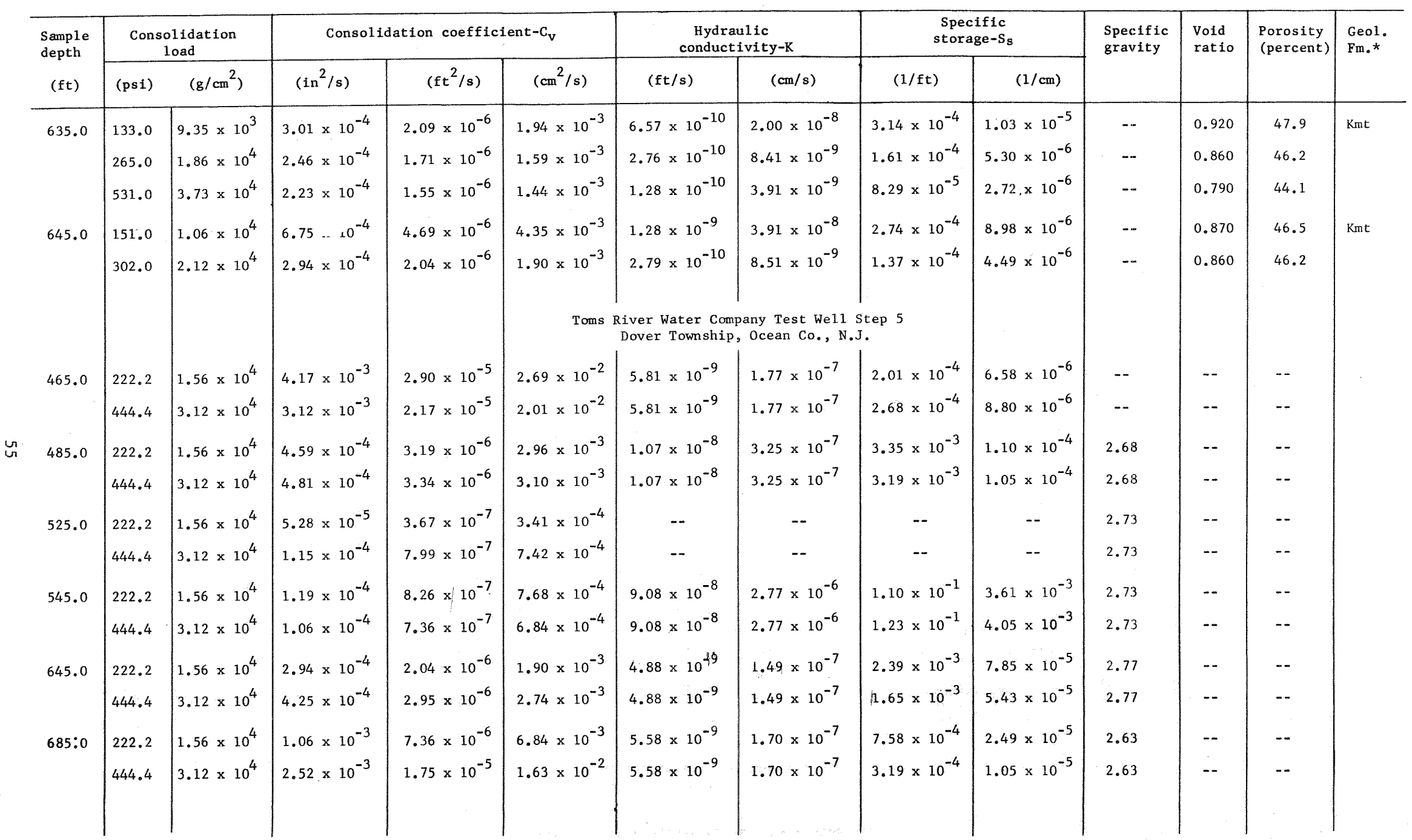


Table 9.--Consolidation Test Data--Continued

Toms River Water Company Test We11 Step 5--Continued Dover Township, Ocean Co., N.J.

\begin{tabular}{|c|c|c|c|c|c|c|c|c|c|c|c|c|c|}
\hline \multirow{2}{*}{$\begin{array}{l}\text { Sample } \\
\text { depth } \\
\text { (ft) }\end{array}$} & \multicolumn{2}{|c|}{$\begin{array}{c}\text { Consolidation } \\
\text { load } \\
\end{array}$} & \multicolumn{3}{|c|}{ Consolidation coefficient- $\mathrm{C}_{\mathrm{v}}$} & \multicolumn{2}{|c|}{$\begin{array}{c}\text { Hydraulic } \\
\text { conductivity-K }\end{array}$} & \multicolumn{2}{|c|}{$\begin{array}{c}\text { Specific } \\
\text { storage- } \mathrm{S}_{\mathrm{s}}\end{array}$} & \multirow[t]{2}{*}{$\begin{array}{l}\text { Specific } \\
\text { gravity }\end{array}$} & \multirow[t]{2}{*}{$\begin{array}{l}\text { Void } \\
\text { ratio }\end{array}$} & \multirow[t]{2}{*}{$\begin{array}{l}\text { Porosity } \\
\text { (percent) }\end{array}$} & \multirow[t]{2}{*}{$\begin{array}{l}\text { Geol. } \\
\text { Fm.* }\end{array}$} \\
\hline & (psi) & $\left(\mathrm{g} / \mathrm{cm}^{2}\right)$ & $\left(i n^{2} / s\right)$ & $\left(\mathrm{ft}^{2} / \mathrm{s}\right)$ & $\left(\mathrm{cm}^{2} / \mathrm{s}\right)$ & $(\mathrm{ft} / \mathrm{s})$ & $(\mathrm{cm} / \mathrm{s})$ & $(1 / f t)$ & $(1 / \mathrm{cm})$ & & & & \\
\hline \multirow[t]{2}{*}{765.0} & 222.2 & $1.56 \times 10^{4}$ & $1.72 \times 10^{-3}$ & $1.19 \times 10^{-5}$ & $1.11 \times 10^{-2}$ & $7.35 \times 10^{-8}$ & $2.24 \times 10^{-6}$ & $6.15 \times 10^{-3}$ & $2.02 \times 10^{-4}$ & 2.75 & -- & -- & \\
\hline & 444.4 & $3.12 \times 10^{4}$ & $1.61 \times 10^{-3}$ & $1.12 \times 10^{-5}$ & $1.04 \times 10^{-2}$ & $7.35 \times 10^{-8}$ & $2.24 \times 10^{-6}$ & $6.57 \times 10^{-3}$ & $2.16 \times 10^{-4}$ & 2.75 & -- & -- & \\
\hline \multirow[t]{2}{*}{775.0} & 222.2 & $1.56 \times 10^{4}$ & $5.79 \times 10^{-4}$ & $4.02 \times 10^{-6}$ & $3.74 \times 10^{-3}$ & -- & -- & -- & - & 2.66 & -- & - & \\
\hline & 444.4 & $3.12 \times 10^{4}$ & $1.02 \times 10^{-4}$ & $7.08 \times 10^{-7}$ & $6.58 \times 10^{-4}$ & -- & -- & -- & - & 2.66 & -- & -- & \\
\hline \multirow[t]{2}{*}{785.0} & 222.2 & $1.56 \times 10^{4}$ & $3.59 \times 10^{-4}$ & $2.49 \times 10^{-6}$ & $2.32 \times 10^{-3}$ & -- & - & -- & -- & 2.73 & -- & -- & \\
\hline & 444.4 & $3.12 \times 10^{4}$ & $4.91 \times 10^{-4}$ & $3.41 \times 10^{-6}$ & $3.17 \times 10^{-3}$ & -- & -- & -- & -- & 2.73 & -- & -- & \\
\hline \multirow[t]{2}{*}{795.0} & 222.2 & $1.56 \times 10^{4}$ & $2.11 \times 10^{-4}$ & $1.47 \times 10^{-6}$ & $1.36 \times 10^{-3}$ & -- & -- & -- & -- & 2.82 & -- & -- & \\
\hline & 444.4 & $3.12 \times 10^{4}$ & $1.95 \times 10^{-4}$ & $1.35 \times 10^{-6}$ & $1.26 \times 10^{-3}$ & -- & -- & $\cdots$ & - & 2.82 & -- & -- & \\
\hline \multirow[t]{3}{*}{805.0} & 222.2 & $1.56 \times 10^{4}$ & $1.41 \times 10^{-3}$ & $9.79 \times 10^{-6}$ & $9.10 \times 10^{-3}$ & $1.73 \times 10^{-9}$ & $5.28 \times 10^{-8}$ & $1.77 \times 10^{-4}$ & $5.81 \times 10^{-6}$ & 2.66 & - & -- & \\
\hline & 444.4 & $3.12 \times 10^{4}$ & $7.92 \times 10^{-4}$ & $5.50 \times 10^{-6}$ & $5.11 \times 10^{-3}$ & $1.73 \times 10^{-9}$ & $5.28 \times 10^{-8}$ & $3.15 \times 10^{-4}$ & $1.03 \times 10^{-5}$ & 2.66 & -- & -- & \\
\hline & & & & & Lat & $\begin{array}{l}\text { New Jersey Wa } \\
\text { ewood Township }\end{array}$ & $\begin{array}{l}\text { er Co. Well } 10 \\
\text { Ocean County, }\end{array}$ & .J. & & & & & \\
\hline \multirow[t]{4}{*}{566.0} & 100.0 & $7.03 \times 10^{3}$ & -- & -- & -- & $1.29 \times 10^{-8}$ & $3.93 \times 10^{-7}$ & -- & -- & -- & -- & -- & $\mathrm{Kmt}$ \\
\hline & 275.0 & $1.93 \times 10^{4}$ & $1.33 \times 10^{-2}$ & $9.21 \times 10^{-5}$ & $8.56 \times 10^{-2}$ & $6.45 \times 10^{-9}$ & $1.96 \times 10^{-7}$ & $7.0 \times 10^{-5}$ & $2.29 \times 10^{-6}$ & $\cdots$ & -- & -- & \\
\hline & 435.0 & $3.06 \times 10^{4}$ & $1.51 \times 10^{-2}$ & $1.05 \times 10^{-4}$ & $9.75 \times 10^{-2}$ & $5.69 \times 10^{-9}$ & $1.73 \times 10^{-7}$ & $5.4 \times 10^{-5}$ & $1.77 \times 10^{-6}$ & -- & -- & -- & \\
\hline & 685.0 & $4.82 \times 10^{4}$ & $1.48 \times 10^{-2}$ & $1.03 \times 10^{-4}$ & $9.57 \times 10^{-2}$ & $4.55 \times 10^{-9}$ & $1.39 \times 10^{-7}$ & $4.4 \times 10^{-5}$ & $1.44 \times 10^{-6}$ & -- & - & -- & \\
\hline \multirow[t]{4}{*}{692.0} & 100.0 & $7.03 \times 10^{3}$ & $1.02 \times 10^{-4}$ & $7.08 \times 10^{-7}$ & $6.58 \times 10^{-4}$ & $1.63 \times 10^{-10}$ & $4.96 \times 10^{-9}$ & $2.3 \times 10^{-4}$ & $7.55 \times 10^{-6}$ & -- & -- & -- & Ket \\
\hline & 275.0 & $1.93 \times 10^{4}$ & $6.72 \times 10^{-5}$ & $4.67 \times 10^{-7}$ & $4.34 \times 10^{-4}$ & $6.07 \times 10^{-11}$ & $1.85 \times 10^{-9}$ & $1.3 \times 10^{-4}$ & $4.27 \times 10^{-6}$ & -- & -- & -- & \\
\hline & 435.0 & $3.06 \times 10^{4}$ & $5.41 \times 10^{-5}$ & $3.76 \times 10^{-7}$ & $3.49 \times 10^{-4}$ & $3.42 \times 10^{-11}$ & $1.04 \times 10^{-9}$ & $9.1 \times 10^{-5}$ & $2.99 \times 10^{-6}$ & -- & -- & -- & \\
\hline & 530.0 & $3.73 \times 10^{4}$ & $3.74 \times 10^{-5}$ & $2.60 \times 10^{-7}$ & $2.41 \times 10^{-4}$ & $2.24 \times 10^{-11}$ & $6.83 \times 10^{-10}$ & $8.6 \times 10^{-5}$ & $2.82 \times 10^{-6}$ & -- & -- & -- & \\
\hline
\end{tabular}


Table 9.--Consolidation Test Data--Continued

New Jersey Water Co. Well 10---Continued Lakewood Township, Ocean County, N.J.

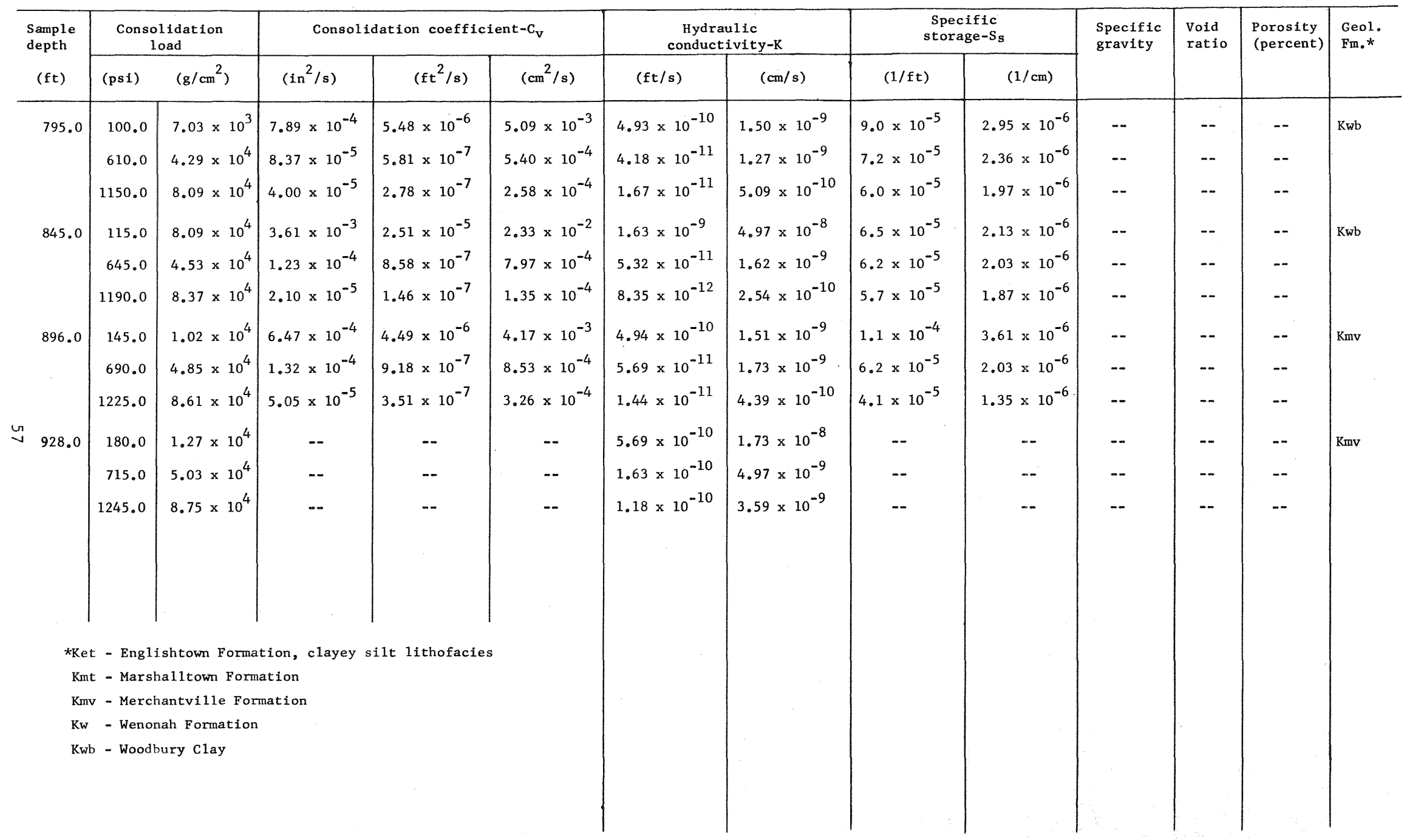


The approximate computed overburden pressure is $300 \mathrm{psi}\left(21.1 \mathrm{~kg} / \mathrm{cm}^{2}\right)$ for the Marshalltown sample and ranges from $360 \mathrm{psi}\left(25.3 \mathrm{~kg} / \mathrm{cm}^{2}\right)$ to 480 psi $\left(33.8 \mathrm{~kg} / \mathrm{cm}^{2}\right)$ for the Merchantville-Woodbury samples. The hydraulic conductivity calculated for the Marshalltown for the load increment closest to overburden pressure is $3.0 \times 10^{-9} \mathrm{ft} / \mathrm{s}\left(9.1 \times 10^{-8} \mathrm{~cm} / \mathrm{s}\right)$; the specific storage is $1.1 \times 10^{-4} \mathrm{ft}^{-1}\left(3.62 \times 10^{-6} \mathrm{~cm}^{-1}\right) ;$ and the hydraulic diffusivity is $2.72 \times 10^{-5} \mathrm{ft}^{2} / \mathrm{s}\left(2.53 \times 10^{-2} \mathrm{~cm}^{2} / \mathrm{s}\right)$. Hydraulic conductivity values of the Merchantville-Woodbury samples computed for load increments nearest the approximate overburden pressures range from $4.25 \times 10^{-11} \mathrm{ft} / \mathrm{s}\left(1.29 \times 10^{-9}\right.$ $\mathrm{cm} / \mathrm{s})$ to $6.92 \times 10^{-10} \mathrm{ft} / \mathrm{s}\left(2.11 \times 10^{-8} \mathrm{~cm} / \mathrm{s}\right)$. Specific storage values range from $6.54 \times 10^{-5} \mathrm{ft}^{-1}\left(2.14 \times 10^{-6} \mathrm{~cm}^{-1}\right)$ to $4.66 \times 10^{-4} \mathrm{ft}^{-1}(1.53 \mathrm{x}$ $\left.10^{-5} \mathrm{~cm}^{-1}\right)$. The hydraulic diffusivity of these samples varies from $2.97 \mathrm{x}$ $10^{-7} \mathrm{ft}^{2} / \mathrm{s}\left(2.76 \times 10^{-4} \mathrm{~cm}^{2} / \mathrm{s}\right)$ to $6.59 \times 10^{-6} \mathrm{ft}^{2} / \mathrm{s}\left(6.12 \times 10^{-3} \mathrm{~cm}^{2} / \mathrm{s}\right)$ (table 9).

Samples of the Marshalltown Formation, the clayey silt lithofacies of the Englishtown Formation, and the Woodbury and Merchantville Formations were obtained from a well drilled by the New Jersey Water Company near Lakewood, N.J. The Marshalltown Formation sample, collected at a depth of $566 \mathrm{ft}(172 \mathrm{~m})$, is in the sand-silt-clay category of the Shepard classification. A sample of the clayey silt lithofacies of the Englishtown Formation was taken at a depth of $692 \mathrm{ft}(211 \mathrm{~m})$ and is a silty clay in Shepard's classification system. Four samples of the Merchantville and Woodbury Formations were obtained between depths of $795 \mathrm{ft}(242 \mathrm{~m})$ and $928 \mathrm{ft}(283 \mathrm{~m})$. The sediments recovered fall in the clayey silt and sand-silt-clay categories of the Shepard classification system.

The approximate computed overburden pressure is $440 \mathrm{psi}\left(30.9 \mathrm{~kg} / \mathrm{cm}^{2}\right)$ for the Marshalltown sample, $540 \mathrm{psi}\left(38 \mathrm{~kg} / \mathrm{cm}^{2}\right)$ for the clayey silt lithofacies sample of the Englishtown, and ranges from $620 \mathrm{psi}\left(43.6 \mathrm{~kg} / \mathrm{cm}^{2}\right)$ to $710 \mathrm{psi}\left(50 \mathrm{~kg} / \mathrm{cm}^{2}\right.$ ) for the Merchantville-Woodbury samples. The hydraulic conductivity calculated for the Marshalltown for the consolidation load closest to overburden pressure is $5.69 \times 10^{-9} \mathrm{ft} / \mathrm{s}\left(1.73 \times 10^{-7} \mathrm{~cm} / \mathrm{s}\right)$ and the specific storage is $5.45 \times 10^{-5} \mathrm{ft}^{-1}\left(1.77 \times 10^{-6} \mathrm{~cm}^{-1}\right)$. The hydraulic conductivity calculated for the clayey silt lithofacies of the Englishtown Formation is $2.24 \times 10^{-11} \mathrm{ft} / \mathrm{s}\left(6.83 \times 10^{-10} \mathrm{~cm} / \mathrm{s}\right)$, and the specific storage is $8.6 \times 10^{-5} \mathrm{ft}^{-1}\left(2.82 \times 10^{-6} \mathrm{~cm}^{-1}\right)$. Hydraulic conductivity values of the Merchantville and Woodbury Formation samples calculated for load increments nearest the approximate overburden pressures range from $4.18 \times 10^{-11} \mathrm{ft} / \mathrm{s}$ $\left(1.27 \times 10^{-9} \mathrm{~cm} / \mathrm{s}\right)$ to $1.63 \times 10^{-10} \mathrm{ft} / \mathrm{s}\left(4.97 \times 10^{-9} \mathrm{~cm} / \mathrm{s}\right)$. Specific storage values range from $6.2 \times 10^{-5} \mathrm{ft}^{-1}\left(2.03 \times 10^{-6} \mathrm{~cm}^{-1}\right)$ to $7.2 \times 10^{-5} \mathrm{ft}^{-1}$ $\left(2.36 \times 10^{-6} \mathrm{~cm}^{-1}\right)$. The hydraulic diffusivity of these samples varies from. $5.81 \times 10^{-7} \mathrm{ft}^{2} / \mathrm{s}\left(5.40 \times 10^{-4} \mathrm{~cm}^{2} / \mathrm{s}\right)$ to $9.18 \times 10^{-7} \mathrm{ft}^{2} / \mathrm{s}\left(8.53 \times 10^{-4} \mathrm{~cm}^{2} / \mathrm{s}\right)$. The average and extreme values of the hydraulic conductivity of the confining layers of the Englishtown aquifer system are given in table 4. 
The geohydrologic data contained in this report are the basic requirements needed in the development of a computer simulation model of the most developed part of the Englishtown aquifer in the northern Coastal Plain of New Jersey. The Englishtown aquifer, which has an average thickness of about 100 feet $(30 \mathrm{~m})$ throughout Monmouth and northern Ocean Counties, is sandwiched between overlying and underlying confining beds that have an average thickness of 40 ft $(12 \mathrm{~m})$ and $200 \mathrm{ft}(61 \mathrm{~m})$ respectively.

The transmissivity of the aquifer is relatively low, ranging from 2,400 $\mathrm{ft}^{2} / \mathrm{d}\left(223 \mathrm{~m}^{2} / \mathrm{d}\right)$ to $650 \mathrm{ft}^{2} / \mathrm{d}\left(60 \mathrm{~m}^{2} / \mathrm{d}\right)$; the hydraulic conductivity averages about $15 \mathrm{ft} / \mathrm{d}(3.3 \mathrm{~m} / \mathrm{d})$; and the storage coefficient ranges from $8 \times 10^{-5}$ to $3 \times 10^{-4}$. The confining beds have vertical hydraulic conductivities on the order of $1 \times 10^{-5} \mathrm{ft} / \mathrm{d}\left(3 \times 10^{-6} \mathrm{~m} / \mathrm{d}\right)$ and specific storage of $8 \times 10^{-5} / \mathrm{ft}$ $\left(2.4 \times 10^{-5} / \mathrm{m}\right)$.

The average rate of withdrawal from the Englishtown aquifer, within the area of study increased from $5.5 \mathrm{Mgal} / \mathrm{d}(.24 \mathrm{~m} 3 / \mathrm{s})$ in 1959 to about $9.5 \mathrm{Mgal} / \mathrm{d}$ $\left(0.4 \mathrm{~m}^{3} / \mathrm{s}\right)$ in 1970 . The effect of this withdrawal rate was a decline in head as of 1970 at a rate of 8 to $12 \mathrm{ft}(2.4$ to $3.6 \mathrm{~m})$ per year over large areas. As a consequence of this change in head, large quantities of water have apparently leaked from and through the confining layers into the Englishtown aquifer. The quantity of leakage and the effects of future stresses on the aquifer can best be estimated by simulation modeling.

\section{REFERENCES CITED}

Anderson, H. R., and Appe1, C. A., 1969, Geology and ground-water resources of Ocean County, New Jersey: New Jersey Dept. Conserv, and Econ. Devel. Spec. Rept. 29, 93 p., 29 figs.

Barksdale, H. C., Greenman, D. W., Lang, S. M., Hilton, G. S., and Outlaw, D. E., 1958, Ground-water resources of the tri-state region adjacent to the lower Delaware River: New Jersey Dept. Conserv, and Econ. Deve1. Spec. Rept. 13, 190 p., 1 pl., 24 figs.

Berry, E. W., 1906, The flora of the Cliffwood clays: New Jersey Geol. Survey Ann. Rept., 1905, p. 135-172.

Domenico, P. A., and Mifflin, M. D., 1965, Water from low-permeability sediments and 1and subsidence: Water Resources Research, vol. 1, no. 4, p. 563-576.

Donsky, E1lis, 1963, Records of wells and ground-water quality in Camden County, New Jersey: New Jersey Dept. Conserv, and Econ. Devel. Water Resòurces Circ. 10, 70 p. 
Farlekas, G. M., Nemickas, Bronius, and Gill, H. E., 1976, Geology and ground-water resources of Camden County, New Jersey: U.S. Geol. Survey Water Resources Inv. 76-76, 146 p.

Hantush, M. S., 1960, Modification of the theory of leaky aquifers: Jour. Geophys. Research, v. 65, no. 11, p. 3713-3725.

1964, Hydraulics of wells, in Chow, V. T., Advances in hydroscience, v. 1: New York, Academic Press, p. 281-442.

Hardt, W. F., 1963, Public water supplies in Gloucester County, New Jersey: New Jersey Dept. Conserv. and Econ. Devel. Water Resources Circ. 9.

Hardt, W. F., and Hilton, G. S., 1969, Water Resources and geology of Gloucester County, New Jersey: New Jersey Dept. Conserv, and Econ. Deve1. Spec. Rept. 30, 130 p., 17 figs.

Hurr, R. T., 1966, A new approach for estimating transmissibility from specific capacity: Water Resources Research, v. 2, no. 4, p. 657-664.

Jablonski, L. A., 1959, Records of wells and ground-water quality in Monmouth County, New Jersey: New Jersey Dept. Conserv. and Econ. Devel. Water Resources Circ. 2.

1960, Factual data for public-supply wells and selected irrigation wells in Monmouth County, New Jersey: New Jersey Dept. Conserv. and Econ. Devel. Water Resources Circ. 4.

1968, Ground-water resources of Monmouth County, New Jersey: New Jersey Dept. Conserv, and Econ. Deve1. Spec. Rept. 23, 117 p., 27 figs.

Lambe, W. T., 1951, Soil testing for engineers: New York, John Wiley and Sons, Inc., $165 \mathrm{p}$.

Minard, J. P., 1964, Geology of the Roosevelt Quadrangle, New Jersey: U.S. Geo1. Survey Geo1. Quad. Map GQ -340 .

1965, Geologic map of the Woodstown Quadrangle, Gloucester and Salem Counties, New Jersey: U.S. Geol. Survey Geol. Quad. Map GQ-340.

1969, Geology of the Sandy Hook Quadrangle in Monmouth County, New Jersey: U.S. Geol. Survey Bul1. 1276, 43 p.,2 pls., 14 figs.

Minard, J. P., Owens, J. P., and Nichols, T. C., 1964, Pre-Quaternary geology of the Mount Holly Quadrangle, New Jersey: U.S. Geol. Survey Geol. Quad. Map GQ-272. 
Minard, J. P., Owens, J. P., Soh1, N. F., Gi11, H. E., and Me11o, J. F., 1969, Cretaceous-Tertiary boundary in New Jersey, Delaware, and eastern Maryland: U.S. Geol. Survey Bul1. 1274-H, 33 p., 10 figs.

Owens, J. P. and Minard, J. P., 1966, Pre-Quaternary geology of the Allentown Quadrangle, New Jersey: U.S. Geo1. Survey Geo1. Quad. Map GQ-566.

1970, Rock stratigraphic studies, in Owens, J. P., and others, Stratigraphy of the outcropping post-Magothy Upper Cretaceous formations in southern New Jersey and northern Delmarva Peninsula: U.S. Geol. Survey Prof. Paper 674, p. 5-10.

Owens, J. P., Minard, J. P., and Soh1, N. F., 1968, Cretaceous deltas in the northern New Jersey Coasta1 Plain, in Finks, R. L., ed., Guidebook to field excursions at the 40th Annual Meeting of the New York State Geologists Association: New York, Queens College of the City Univ., p. $33-48$.

Owens, J. P., Minard, J. P., Soh1, N. F., and Mel1o, J. F., 1970, Stratigraphy of the outcropping post-Magothy Upper Cretaceous formations in southern New Jersey and northern Delmarva Peninsula, Delaware and Maryland: U.S. Geol. Survey Prof. Paper 674, 60 p., 25 figs.

Owens, J. P., and Soh1, N. F., 1969, Shelf and deltaic paleoenvironments in the Cretaceous-Tertiary formation of the New Jersey Coastal Plain, in Subitzky, Seymour, ed., Geology of selected areas in New Jersey and eastern Pennsylvania and guidebook of excursions: Geol. Soc. America and Associated Societies Ann. Mtg., Atlantic City, New Jersey, 1969, p. 235-278.

Parker, G. G., Hely, A. G., Keighton, W. D., Olmstead, F. H., and others, 1964, Water resources of the Delaware River Basin: U.S. Geol. Survey Prof. Paper 381, 200 p., 12 pls., 75 figs.

Rosenau, J. C., Lang, S. M., Hilton, G. S., and Rooney, J. G., 1969, Geology and ground-water resources of Salem County, New Jersey: New Jersey Dept. Conserv. and Econ. Devel. Spec. Rept. 33, 142 p., 21 figs.

Rush, F. E., 1968, Geology and ground-water resources of Bur1ington County, New Jersey: New Jersey Dept. Conserv. and Econ. Devel. Spec. Rept. 26, 65 p., 25 figs.

1962, Records of wells and ground-water quality in Burlington County, New Jersey: New Jersey Dept. Conserv. and Econ. Devel. Water Resources Circ. 7.

Seaber, P. R., 1965, Variations in chemical character of water in the Englishtown Formation, New Jersey: U.S. Geo1. Survey Prof. Paper 498-B, 35 p., 9 figs. 
Shepard, F. P., 1954, Nomenclature based on sand-silt-clay ratios: Jour. Sed. Petrology, v. 24, no. 3, p. 151-158.

Theis, C. V.: 1935, The relation between the lowering of piezometric surface and the rate and duration of discharge of a well using ground-water storage: Trans. Am. Geophys. Union 16th Ann. Mtg., pt. 2.

Vecchioli, John and Palmer, M. M., 1962, Ground-water resources of Mercer County, New Jersey: New Jersey Dept. Conserv, and Econ. Devel. Spec. Rept. 19, 17 p., 13 figs. 